Portland State University

PDXScholar

$1-1-2011$

\title{
Diminished Democracy? Portland Radio News/ Public Affairs After the Telecom Act of 1996
}

Rebecca Webb

Portland State University

Follow this and additional works at: https://pdxscholar.library.pdx.edu/open_access_etds Let us know how access to this document benefits you.

Recommended Citation

Webb, Rebecca, "Diminished Democracy? Portland Radio News/Public Affairs After the Telecom Act of 1996" (2011). Dissertations and Theses. Paper 157.

https://doi.org/10.15760/etd.157

This Thesis is brought to you for free and open access. It has been accepted for inclusion in Dissertations and Theses by an authorized administrator of PDXScholar. Please contact us if we can make this document more accessible: pdxscholar@pdx.edu. 


\title{
Diminished Democracy?
}

Portland Radio News/Public Affairs After the Telecom Act of 1996

by

Rebecca Webb

A thesis submitted in partial fulfillment of the requirements for the degree of

\author{
Master of Arts \\ in \\ Political Science
}

\section{Thesis Committee: \\ Craig Carr, Chair \\ Christopher Shortell \\ Gerald Sussman}

\author{
Portland State University \\ (C)2011
}




\begin{abstract}
News and public affairs on commercial radio dramatically changed following the 1996 Telecom Act, with rapid consolidation and economic efficiencies radically shrinking commercial radio's role in the provision of political information. By examining jobs data, public files, and the views of broadcast journalists, this project assesses the Act's impact through the lens of civic-minded Portland, Oregon. Because political information enables democracy, and because of radio's uniquely accessible qualities, this paper argues that market emphasis in media policy — especially in the Act's absolute manifestation - has diminished a significant channel of public discourse. Noticing radio's democratic potential, still relevant in the digital age, this work offers support for a revival of discursive opportunities on local commercial radio.
\end{abstract}




\section{Dedication}

To Mike, who did a lot of cooking and proofreading. 


\section{Acknowledgments}

\section{Thanks so much to those who contributed to this project!}

To my committee chair, Dr. Craig Carr, for his incisive observations and continuing support.

To committee member, Dr. Christopher Shortell, for his astute, reliable guidance.

To Dr. Gerald Sussman, also on my committee, for his critical perspective and willing advice.

I am indebted to certain Portland radio industry leaders who, in the course of their careers, demonstrated how local stations could serve their community. Journalist Jacob Lewin, Station Manager Paul Clithero, and Public Affairs Producer Lacy Turner greatly enhanced this project.

To all the broadcasters who confidentially provided crucial insight into the state of news/public affairs on Portland's commercial stations, thank you! I am honored by your trust.

Thanks to Ellen Moscoe, whose humor and skills led to successfully aggregated survey data and pretty graphs.

For their advice and support, I am grateful to research experts Silvo Lenart and Mike Riley. Their assistance lent a professional touch to my Radio Survey 2011.

And, for her Southern hospitality, I applaud Mary Palmer Linneman at the University of Georgia Hargrett Library, who drove to an off-campus library repository to locate Arbitron records from the 1990s. 
Table of Contents

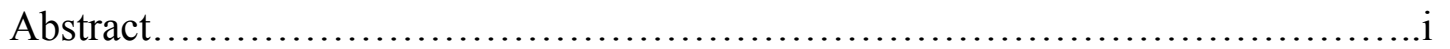

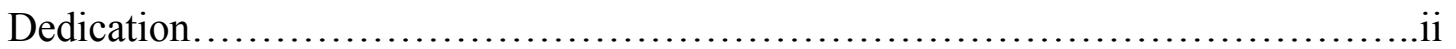

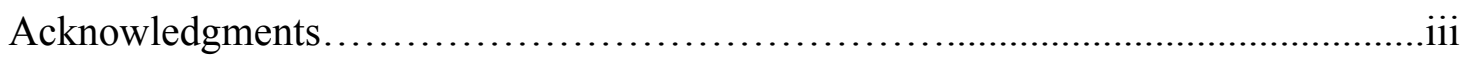

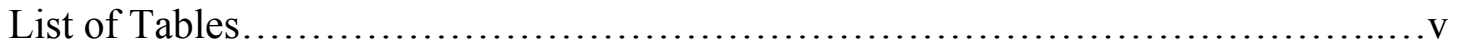

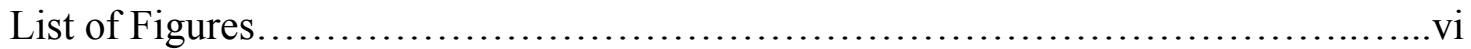

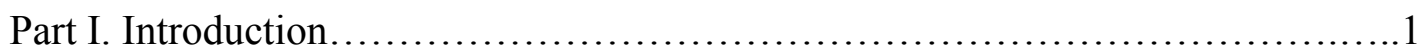

Part II. Purpose of the Paper, Research Question, Literature, Methods...............5

Part III. Historical Perspective

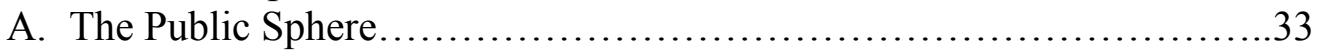
B. Radio.........................................................42
C. Radio's Unique Qualities and Democratic Potential......................57
D. Why Radio Still Matters in the Internet Era.........................60

Part IV. Presentation of the Research: The View from Portland
A. Fewer Owners.....................................................63

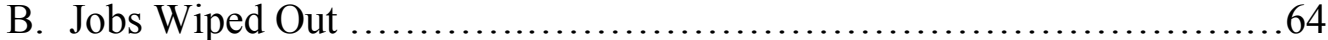
C. Diminished Local News/Public Affairs ................................66 67
D. Conclusions............................................... 76

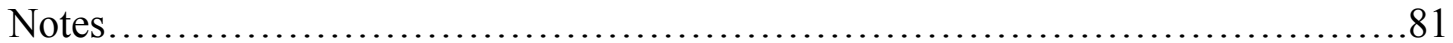

Works Cited................................................................ 88

Cases Cited ............................................................ 102

Appendices $\quad$ A. 1960 Program Policy Statement.....................103

B. Portland Stations Ownership History...............104

C. Portland Stations Arbitron Ratings.................109

D. Portland Top 12 (rank, format, owner 1996-97)...110

E. Portland Top 12 (rank, format, owner 2011)........111

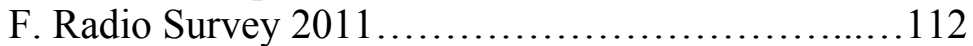

G. Spike in Acquisitions Nationwide..................128

H. Portable People Meter..........................129

I. Employee Data per SEC Filings....................130

J. KGON News/Public Affairs/PSAs................132

K. KWJJ News/Public Affairs/PSAs...................135

L. KOPB Ratings..................................138

M. Shared Public Affairs Programs...................139 


\section{List of Tables}

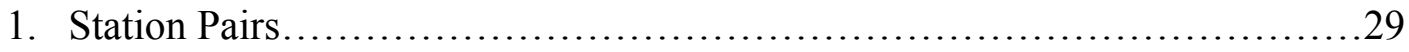

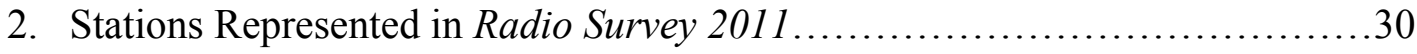

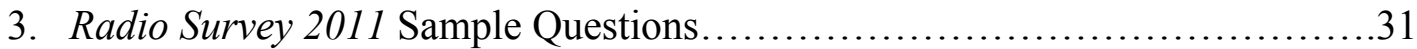

4. Clear Channel Per-Station Employee Average.................................65

5. Entercom Per-Station Employee Average ...................................66

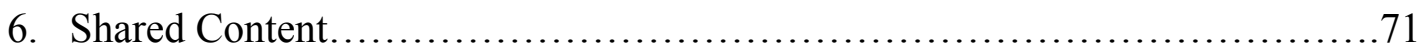

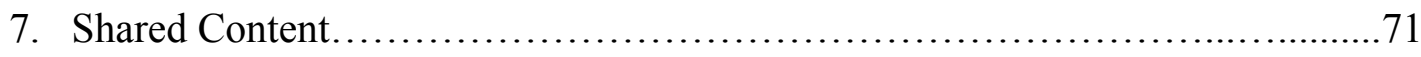

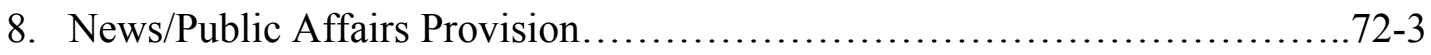




\section{List of Figures}

1. McChesney-Nichols Chart: Decline in Broadcast News Jobs..................27

2. Possible Reasons for Decline in News/Public Affairs: Ownership Cost-Cutting 73

3. Buy-Outs by Larger Companies....................................... 74

4. Audiences Prefer Non-News........................................ 74

5. People Can Get Local News Elsewhere..$\ldots \ldots \ldots \ldots \ldots \ldots \ldots \ldots \ldots \ldots \ldots \ldots \ldots \ldots$

6. Journalist's Ability Limited by Current Radio Environment..................75 


\section{Part I. Introduction}

Because media provide our world-view, they have profound power to shape public opinion and to influence laws we give to ourselves. Relinquishing control of such consequential forces, leaving them to chance (whatever the market decides), risks abandonment of an important democratic goal: an informed, engaged citizenry. Since the early 1980s, local radio news/public affairs - a once-vibrant source of citizen information and engagement - has declined at the hands of market forces, culminating with passage of the 1996 Telecommunications Act. ${ }^{1}$ This paper asks: What were the Act's consequences for radio news/public affairs in Portland, OR, and why do they matter?

Through the lens of commercial radio in Portland, ${ }^{2}$ I will argue that the Act led to three dubious effects that truncated democratic opportunities for local radio listeners. First, rapid post-Act consolidation placed many owners hundreds or thousands of miles away from communities, distancing them from local concerns. Second, by incentivizing broadcast news layoffs, Act-enabled economies of scale effectively transferred many journalistic judgments from local to centralized operations_-or eliminated them altogether. Finally, local news/public affairs, already weakened by years of deregulation, further eroded or collapsed—shrinking radio opportunities for citizen engagement and diminishing local radio's political role.

To indicate the significance of what the Telecom Act has wrought, its harm to democracy, this paper rests on three underlying premises which I am obliged to support: that political information is vital to democratic opportunities (in part II), that radio can make a unique (that is, non-substitutable) contribution to such opportunities (in part III), and that the Act — not something else - led to the described injury to radio news/public 
affairs (in part IV). To begin, then, part II establishes the first of these assertions - that democratic opportunities depend on political information.

Drawing from journalism, communications, and political theory, I define news/public affairs and sketch the political functions of broadcast journalism that inhere in democracy. Generally, these are: to facilitate politics (by conveying information between citizens and government), to call attention to important issues (agenda-setting), and to offer a forum for public discourse. Because of its progressive political innovations, Portland, my case study, is a fertile subject for research into radio's political role. Thus, I briefly describe Portland's robust civic activism, and conclude part II with a summary of the pertinent (Act-related) literature-which informed the Portland project.

To appreciate radio's political role as a mediator of the public sphere-its unique provision of democratic opportunities, my second underlying premise-I offer in part III a summary of related historical, doctrinal, and regulatory events. Throughout broadcast history, U.S. Supreme Court rulings have fed the rationale for media policy, with nuanced interpretations of the First Amendment (marketplace of ideas, watchdog, selfrealization, public deliberation). However, the rising influence of economic forces in media policy increasingly subordinated those regulatory rationales to the economic marketplace.

Foreshadowing implementation of the Telecom Act, this chapter marks the transition from the (regulated) "trustee" model to the (less-regulated) "market" model in radio policy. Although both models purport to serve the public interest, and each has appealing features, so, too, is each model flawed, as I will detail. However, I find that the market model—by imposing an economic frame on a public good—seriously undermines 
political discourse, an effect heightened by the Telecom Act. Valuing only outcomes expressed as economic "preferences," the market model disregards the local duties of broadcasters and squanders the unique (and still relevant) democratic potential of local radio. In this section I discuss radio's extraordinary accessibility (affordability, timeliness, ubiquity) and refute the contention that new media options such as the Internet make ownership concerns, and radio itself, obsolete.

To defend my claim that, by dissociating many owners from their communities of license and jettisoning journalism jobs, the Telecom Act impaired local radio news/public affairs, I looked into station ownership, jobs data, and programming content before and after the Act. If local patterns were similar to national trends, I expected local effects would likely be comparable: Distant owners, employing fewer local journalists, would have had less engagement with listeners, curtailing democratic opportunities via commercial radio. At both the national and local level, the post-Act period is characterized by a notable shift in listenership from commercial to non-commercial radio, implying inadequate provision of political information by commercial radio. ${ }^{3}$ To further establish my thesis, that the Act diminished local news/public affairs to anti-democratic effect, I reviewed stations' public files and surveyed broadcast news professionals. What I found comprises part IV.

During 30 years in broadcasting, mostly in Portland radio news, I observed firsthand the decline in news/public affairs, particularly sharp in the aftermath of the Act. Although drastically curtailing radio's political role, the shift in program content (away from local news/public affairs) took place without public discussion or democratic approval — despite public ownership of the airwaves. This paper offers support for a 
return to pre-Telecom Act ownership limits, expanded institutional support for political discourse, and the placement of radio spectrum policy on the public agenda. 


\section{Part II. Purpose of the Paper, Research Question, Literature, Methods}

There have been great societies that did not use the wheel, but there have been no societies that did not tell stories.

\section{A. Purpose of the Paper}

Ursula K. LeGuin

Listeners tuning in the radio in Portland, Oregon, heard something new in the waning years of the twentieth century: the same content broadcast in thousands of other American cities. Instead of music and news they were used to, listeners received tailored, tested formats with less community information, and music often chosen by distant owners rather than by local disc jockeys. What listeners heard was the product of the market model, a laissez-faire approach to broadcasting that leaves content to listener "preferences" rather than to any design aimed at social goals.

By the time the market model—launched during the Reagan era—reached its apex in 1996, local news/public affairs was already in decline on commercial radio, the victim of more than a decade of undoing broadcasters' traditional fiduciary obligations (deregulation), and competitive challenges from new digital technology (e.g. CDs and portable listening devices). ${ }^{4}$ The Telecom Act of 1996 distinctly exacerbated that trend, impairing or extinguishing local news/public affairs on many stations nationwide. Does the atrophy of substantial local informational content on commercial radio matter, especially in the Internet era?

The purpose of this paper is to describe the loss of local informational (especially political) radio programming - and to suggest that it matters, perhaps in profound ways that have been insufficiently considered. Through the lens of Portland commercial radio, this work argues that market emphasis in media policy, notably in its extreme application, the Telecom Act, has diminished a vital democratic link between citizens and public life. 
By degrading or eliminating local news/public affairs (including public service announcements), the Act curtailed local radio's political role: facilitating citizen/government communications, agenda-setting, and offering a publicity platform for local individuals and groups to express their concerns. To make my case that the Act's consequences have had specifically political implications, I need to show that democratic opportunities depend on the kind of information conveyed by local news/public affairs. Thus I begin by defining news/public affairs.

\section{What is news/public affairs?}

Although tension reigns over what precisely the press (including electronic channels) should deliver in a democracy, theorists generally agree the media ought to publicize information of public interest on a regular basis. Throughout much of the twentieth century, this normative expectation evolved into a set of routines and practices institutionalized by professional journalism, purportedly informed by political theory, and widely accepted by the public as news and public affairs. I merge them here into news/public affairs since, for purposes of this analysis, they serve the same theoretical function. Although a greater sense of timeliness ("This just in...") attends the traditional journalistic account of news compared with public affairs, both can contribute to democratic communication: by linking individuals with their representatives and their communities, placing events in a context, and offering a discussion forum for "the issues which bear upon our common life" (Meiklejohn [1948] 1960, 75).

Defining news/public affairs is at once deceptively simple and impossibly complex, since it can mean almost anything: "information not previously known to someone," traced to Latin, nova, "new things." As Associated Press leader Melville 
Stone ([1914] 2011) put it, the news should be "...a truthful, unbiased report of the world's happenings..." Lippmann (1922) employed a metaphor from horticulture to explain it:

The news does not tell you how the seed is germinating in the ground, but it may tell you when the first sprout breaks through the surface. It may even tell you what somebody says is happening to the seed under ground...[or] that the sprout did not come up at the time it was expected. The more points, then, at which any happening can be fixed, objectified, measured, named, the more points there are at which news can occur...(in Graber 2007, 48)

Without context (seeing the news item's relation to social consequences) events are empty occurrences (Dewey [1927] 1988, 180). Thus professional journalism infuses news "values" with measuring devices — impact, proximity, timeliness, and so on — to gauge "newsworthiness" (Lanson and Stephens 2008, 11). But, a formulaic approach fails to fully capture what compels a "story."

Anthropologists and historians have found a remarkable consistency over time in the human tendency to share their stories (Stephens 1988). Perhaps this is because, as sociologists suggest, knowledge of events beyond one's personal experience leads to a sense of security, control and confidence (Molotch and Lester 1974). "From the most isolated tribal societies in Africa to the most distant islands in the Pacific, people shared essentially the same definition of what is news." Bonds are formed and characters are judged on the basis of "whether someone reacts to information the same way we do" (Kovach and Rosenstiel 2007, 9).

Part gossip, part folk tale, news can be "hard" or serious, as in a police story, “action-centred” (Breed 1956 in McQuail 2000, 338); or, it can be "soft," with "human interest" content, a contrast more dependent on the presenter's attitude than any intrinsic 
quality (Hughes 1940 in McQuail 2000, 339). Traditional hard news stories comprise myriad topics in these broad categories: government, military, domestic affairs, and foreign affairs (Pew 1998). Because of its ambiguity, news/public affairs often has been framed in terms of journalistic duties or processes - practices formalized in the midtwentieth century. Hence, to pin down the meaning of news/public affairs for this paper, especially in terms of its significance to democracy, I outline what traditional journalism expects of its professionals. As we will see, a large gap has developed between those expectations and contemporary practice.

\section{a. Socially Responsible Media}

The first influential articulation of mainstream journalistic duties issued from an assemblage of distinguished legal, scholarly, and philosophic minds of the World War II era. Noting that agencies of mass communication, increasingly consolidated, were "probably the most powerful single influence [of the day]," the so-called Hutchins Commission declared, the press was obliged to provide:

1. A truthful, comprehensive, and intelligent account of the day's events in a context which gives them meaning

2. A forum for the exchange of comment and criticism

3. A means of projecting the opinions and attitudes of the groups in society to one another (representative picture of the constituents groups)

4. A method of presenting and clarifying the goals and values of the society

5. A way of reaching every member of society by the currents of information (Leigh [1947] 1974, 20-9)

Although flogged from the right as a threat to prevailing media libertarianism, and from the left as an empty chastisement of hegemonic media interests, the report laid the foundation for mainstream journalism values that endured for half a century (Pickard 2010). 
Peterson (1956) embellished the Commission's framework. While nodding to economic and entertainment roles for the media, Peterson saw the social responsibility model indebted foremost to political service through provision of "information, discussion, and debate on public affairs..." (in Siebert, Schramm, and Peterson 1956, 74). And, mid-century professional journalism schools codified the link between press freedom and social responsibility, emphasizing such almost-mythic standards as "objectivity," "fairness," "balance," and "accuracy," that were benchmarks of "nonpurposive communicators" (reporters) with "no ax to grind" and thus no reason to "report the facts other than as they are" (Izard, Culbertson, and Lambert 1973, 3, 186). But, altered institutional routines and practices - a response to economic, technological, and cultural developments of the 1980s — made the content of news/public affairs more elusive (Kovach, Rosenstiel, and Mitchell 1999).

As the public interest obligations of broadcasters were lifted by Reagan-era deregulation (a subject I take up in more detail in part III), certain institutional lines began to blur. For example, business executives rather than journalists were increasingly put in charge of news divisions; market imperatives trumped public interest imperatives; serious news gave ground to a blend of news and entertainment: "infotainment" (Croteau and Hoynes 2006, 167). Many journalists by the 1990s felt trapped in a downward spiral, with economic pressures leading to lower quality stories that increasingly alienated audiences (Kovatch, Rosenstiel, and Mitchell 1999). Moreover, the public increasingly blamed media entities for the corrosive quality of public discourse (Americans 1995; Cappella and Jamieson 1996; Fallows 1996; Pauly 1999). 
After its late-century metamorphosis spawned by these developments, a drastically weakened traditional journalism remained, chastened and rededicated to its principles. ${ }^{6}$ Journalism educators denounced the disparity between democratic ideals intended to animate the American media system (e.g. government watchdog, marketplace of ideas, etc.) and existing media structures. As Gurevitch and Blumler (1993) outlined, press duties were distinctly political:

1. Surveillance of the sociopolitical environment, reporting developments likely to impinge, positively or negatively, on the welfare of citizens

2. Meaningful agenda-setting, identifying the key issues of the day, including the forces that have formed and may resolve them

3. Platforms for an intelligible and illuminating advocacy by politicians and spokespersons of other causes and interest groups

4. Dialogue across a diverse range of views, as well as between power holders (actual and prospective) and mass publics

5. Mechanisms for holding officials to account for how they have exercised power

6. Incentives for citizens to learn, choose, and become involved, rather than merely to follow and kibitz over the political process

7. A principled resistance to the efforts of forces outside the media to subvert their independence, integrity, and ability to serve the audience

8. A sense of respect for the audience member, as potentially concerned and able to make sense of his or her political environment (Gurevitch and Blumler 1993, 270)

But, the authors saw news/public affairs increasingly squeezed out by "a web" of economic, political and cultural pressures: a media landscape whose "flows" were bounded economically by the imperatives of capitalism and a consumer society (Gurevitch and Blumler 1990, 269). Their observation that "entertaining and arresting" programming increasingly supplanted public affairs was confirmed by Pew researchers in 1998: "There has been a shift toward lifestyle, celebrity, entertainment and celebrity crime/scandal in the news..." (Pew 1998). 
Other more recent, similarly traditional approaches mildly revise but essentially reissue the same long-held journalistic tenets with a new patina. Kovach and Rosenstiel, for example, channel Hutchins Commission principles (accuracy, provision of a public forum) and echo Gurevitch and Blumler (emphasis on the watchdog function). But, uniquely, they share the burden of political information with the public (item 10).

1. Journalism's first obligation is to the truth.

2. Its first loyalty is to citizens.

3. Its essence is a discipline of verification.

4. Its practitioners must maintain an independence from those they cover.

5. It must serve as an independent monitor of power.

6. It must provide a forum for public criticism and compromise.

7. It must strive to make the significant interesting and relevant.

8. It must keep the news comprehensive and proportional.

9. Its practitioners must be allowed to exercise their personal conscience. 10. Citizens, as well as journalists, bear many of the same rights and responsibilities. (Kovach and Rosenstiel 2007, 12)

Many of the same social responsibility principles are also found in the ethics statements of professional journalism organizations (e.g. Radio Television Digital News Association; Society of Professional Journalists). ${ }^{8}$ And, the "public (or civic) journalism" movement of the 1990s offers similar fare, but emphasizes a bottom-up approach - more reliance on citizens, less on officials (Pauly 1999).

Unfortunately, the distance between these proclamations of democratic commitments and current broadcast content, especially on commercial radio, indicate market failure at best (Baker 2002a), and propaganda at worst (Herman and Chomsky 2002). Competitive market forces combine to discourage thoughtful news/public affairs production, a trend exacerbated by conglomeration. (Because corporate conglomerate owners squeeze out much higher rates of return, the presently dominant bottom-line objective in media sectors, market forces push toward "cashing out" profits rather than 
using them to subsidize quality journalism (Baker 2002a, 880).) And, since their careers depend on harmony with political and corporate elites, journalists conform, if unconsciously, to establishment ideology (Herman and Chomsky 2002).

\section{b. Nontraditional News/Public Affairs Forms}

Dissatisfaction with traditional journalism has fueled creative forms of discursive engagement, personified by broadcasters/satirists Jon Stewart and Stephen Colbert. ${ }^{9}$ In a "neomodern" inversion of news and entertainment that serves a number of traditional journalism functions, Stewart and Colbert lampoon both politicians and the journalists who have abandoned serious coverage of them (Baym 2010). Holding power to account by shining his media spotlight on a filibustered $9 / 11$ aid bill, for example, Stewart's “advocacy journalism" was likened to that of Murrow and Cronkite (Carter and Stelter 2010). ${ }^{10}$ And, Colbert's "new language of public affairs" is often a subversive critique of the political use of language (Baym 2010).

Nearly one-third of Americans under age 40 said that satirical programs such as The Daily Show and The Colbert Report were more informative than traditional news, and helped shape their political views (Rasmussen 2009). And, Stewart's Daily Show, which began as a news spoof (1999), has become a "provocative and substantive source of news" (Kakutani 2008), which rivals mainstream networks as an important and trusted source of news (Time Polls 2009). ${ }^{11}$ Although college students who watched The Daily Show had less trust in the president, the news media, and the political process (Baumgartner and Morris 2006), apolitical audience members said they paid more attention to issues they previously ignored (Cao 2010). Though Stewart conflates fact and fantasy (and disregards much of what traditionalists consider news) analysts admit his 
program encourages Americans to "think critically about the public square" (Pew Study 2008). Stewart and Colbert viewers scored in the highest percentile in an inquiry into public affairs knowledge (Pew Study 2007). ${ }^{12}$

None of this suggests Stewart/Colbert-style "discursive integration" (to use Baum's term) is an adequate substitute for traditional journalism; it is mentioned here to indicate the unbounded nature of news/public affairs. Nor is it entirely new. Consider decades of Saturday Night Live (and, earlier, All in the Family), cartoons such as Doonesbury (and, earlier, Pogo and Li'l Abner), comics like George Carlin (and, earlier, Lenny Bruce and Mort Sahl). Arguably, they and innumerable others dating back to Horace and Juvenile deployed a satirical version of news/public affairs which address at least some democratic functions long expected of the press - especially holding officials accountable and directing attention to important issues (Baym 2010).

In short, because there is no pat definition for news/public affairs it may best be characterized by its intended functions in democracy. Professional journalism described certain press responsibilities meant to drive news/public affairs content: providing accurate, adequate information, in a context that highlights key issues; disseminating knowledge; furnishing a forum for public discourse, including contrary viewpoints; and supervising powerful officials. Due to a range of pressures, however-economic, technological, and cultural — many of these ideal duties have attenuated over time, leading both to a crisis in journalism and to innovative forms of news/public affairs. With that in mind, I turn to its importance in a self-governing society.

\section{Why is News/Public Affairs Important to Democracy?}

Because they provide citizens with a means of informing themselves and 
expressing political will, media reign over the public sphere. (I will say more about this historical role for the press in part III.) According to democratic theory, this mediation ideally consists of facilitating politics by channeling information to and from citizens, their representatives, and their communities. Since such political information has the power to influence citizens' freedom and equality—-the twin promises of liberalism (Carr 2010) - it is the oxygen of democracy.

An informed citizenry is essential in any but the most farcical democracy (Madison [1822] 1953). It follows that citizens must have the degree of political information that enables their participation in the governing process (Schudson 2002). In a liberal pluralist democracy such as the U.S., that means enough information to understand and argue for their interests (Dahl 1989; Delli Carpini 2000; Schattschneider [1960] 2008). But if democracy prevails only to the extent that citizens' interests are equally taken into account, something more than information flow is implied: It suggests the channels of communication should be closely linked to communities, assessing their needs, and offering platforms for diverse - even unpopular — voices. How else to take the interests of citizens equally into account?

Absent such communication, neither officials nor citizens can effectively perform their theoretical role in the process of self-governance. Officials, without the ability to receive public opinion, would fall short in their (constitutionally presumed) obligation to represent constituents in policy promulgation. And, citizens, unable to obtain and respond to relevant issue information, would thus have their voices (unconstitutionally) removed from the policymaking process. Although not limited by form, as the Stewart/Colbert example demonstrated, provision of political information is the core democratic function 
of media in a self-governing society. The vehicle for that content, news/public affairs, performs several specific functions so familiar they need only a brief review.

\section{a. Holding Officials Accountable}

The watchdog press function (which I explore in part III, the Public Sphere/First Amendment) has been, since the Enlightenment, a security against corrupt government (Mill [1859] 1998). "The press it is whose ever watchful eye exposes the secret motivations of politics and forces men in public life to appear one by one before the court of public opinion" (Tocqueville [1835-40] 2003, 217). However, the press role as a check on government power is seriously weakened when its goals align with officials (Bennett, Lawrence, and Livingston 2008; Cook 2005a), or when market forces place it in the service of corporate power (Coronel 2008; Herman and Chomsky 2002).

In a disturbing recent example, researchers linked misperceptions about events surrounding the Iraq War (2003) to citizens' choice of news outlets. Kull, Ramsey, and Lewis (2003) found significant correlations between ignorance of certain facts (for example, whether weapons of mass destruction had been found in Iraq) and respondents' loyalty to specific news providers. This is of concern if media gatekeepers are, in a democracy, expected to keep the public informed about important policy matters.

\section{b. Providing a Platform for Public Discourse}

Guarding the freedom of public discussion, as Meiklejohn described it, was the first step in "the unending attempt of our nation to be intelligent about its own purposes." By communicating freely about the "values, the opportunities, the difficulties, the joys and sorrows, the hopes, and fears, the plans and purposes of that common life," Americans become a "community of mutual understanding" (Meiklejohn [1948] 1960, 
87). Tocqueville found (1835) America so spread out that newspapers crucially offered citizens a way to "speak to each other without seeing each other," in order to share proposals for joint action, and reach common understandings without actually meeting (Tocqueville [1835-40] 2003, 217).

Dewey saw that communication alone could create a great community —in a country whose size and industrialization had distanced citizens from their government and each other. But, the U.S. did not need random sensationalized bits of trivialized news produced by powerful and interested parties. Public information needed institutional development in the manner of a "genuine social science...contemporary and quotidian," meaning daily, regularized (Dewey [1927] 1988, 180). Over-institutionalization, though, when journalism has "internalized" the ideology of market emphasis, risks the loss of independent or critical perspectives (Herman and Chomsky 2002, 306).

\section{c. Spreading Knowledge}

"Rays of human ability do not radiate from one central point," Tocqueville declared. Thus he saw the proliferation of newspapers (where there were "no licenses for printers, no stamps or registration") as crucial distributors of intelligence (Tocqueville [1835-40] 2003, 214). Dewey called dissemination of information, or the lack of it, the problem of the public. Matters of public life required "inquiry into facts." Not everyone needed to have expert knowledge, he suggested, but through effective communication anyone could learn enough to "judge the bearing of the knowledge supplied by others upon common concerns" (Dewey [1927] 1988, 125, 208). Fortunately, as Dahl pointed out, telecommunications made it possible for "virtually every citizen [to] have information about public issues almost immediately accessible..." (Dahl 1989, 339). 
Democracy itself depended on "educating and informing" citizens such that they were "able to think and act as self-governing citizens" (Meiklejohn [1948] 1960, 86).

\section{d. Airing Diverse Views}

Because it is seminal to democratic theory, fostering free thought is a key media responsibility (Mill [1859] 1998, 20). Social and intellectual uniformity leads to mediocrity (Dewey [1927] 1988, 115). And, since average citizens necessarily rely on experts for information, "prospects for democracy hinge upon the diversity of views among policy specialists and the relative weakness of their common interests as a class" (Dahl 1989, 339). So crucial to self-governance is wide-ranging public discussion that no information may be suppressed, including "opinion, doubt, belief, counterbelief, no relevant information may be kept from [citizens]" (Meiklejohn [1948] 1960, 74-75). The media obligation to a marketplace of ideas is central to First Amendment doctrine, which I summarize in the Public Sphere/First Amendment section of part III. For now, it is enough to note that "uninhibited, robust, and wide-open" debate is implicit in the special constitutional protection that attends speech freedom in the U.S. ${ }^{13}$

\section{e. Publicizing Local Concerns}

Because American citizens make decisions about community resources at the local level, media are responsible for publicizing the ideas, needs, and concerns of residents near them. (Localism is the rationale behind much broadcast policy; see part III, Radio Regulation.) From sanitation to housing, transportation to taxes, Dewey found that without adequate information about local affairs, the public was "eclipsed," too confused to participate effectively in self-governance. "[P]articipation in activities and sharing in results...demand communication as a prerequisite" (Dewey [1927] 1988, 152, his 
emphasis). Moreover, because "human interests are in constant conflict, and cannot all be realized," decisions about community resources (e.g. parks, libraries, schools, soil conservation) rely upon information—so that judgments may be made as to "relative values and mutual implications" (Meiklejohn [1948] 1960, 81).

Since the distribution of societal goods - "who gets what, when, and how"14 in terms of "goods, services, and values" from government ${ }^{15}$ - depends on the ability of individuals and groups to identify and express their interests, the publicity function is integral to democracy. According to this view, a media entity, by publicizing certain information (or not), may influence the fortunes of some one or some thing. Herein lies the heart of press power.

Thus media shape the very character of communities, playing a crucial role in local projects - that realm of public life where citizens associate and contemplate their common future, eluding the isolating effects of individualism (Tocqueville [1835-40] 2003). This "wild complex" of organizations and movements provides a "context of discovery" where citizens' needs, experiences, and identities are shared (Habermas 2004, 307). Ideally, the formal public sphere - comprised of deliberative bodies - takes legislative cues from the problems (and possible solutions) that flow from this informal public sphere. But, as is well documented, whether officials pay attention to citizen concerns rests in great part with the media (Rogers and Dearing, in Doris Graber 2007, 81; Iyengar, Peters, and Kinder 1982, 849).

My aim in this section has been to establish the first necessary premise for this paper: that democratic opportunities depend on political information. Since Lasswell's first statement (1948) of societal functions performed by communications - surveillance 
of the environment, correlation of societal segments in response to the environment, and transmission of cultural heritage - scholars have reaffirmed that political information is the key to self-governance. Its absence or distortion can have disruptive or harmful consequences (in McQuail 2000). Whether assenting to the leadership of elites or actively engaging in civic affairs, political information enables citizen participation (Schudson 2002).

Especially in a pluralist system, in which individuals and groups vie for a share of societal goods, information (adequate to understanding and lobbying for one's own interest) can determine welfare (Delli Carpini 2000, Schattschneider [1960] 2008). Cooperation in joint community projects, judgments about shared resources, holding officials to account — all rest on access to information (Dewey [1927] 1988; Meiklejohn [1948] 1960; Tocqueville [1835-1840] 2003). So inseparable is political information from a republic that the founders privileged the press with extraordinary protection in the First Amendment.

\section{Why Portland?}

Among the social responsibilities of the press, this paper is particularly interested in publicity for local concerns. Zooming in on this function in Portland, my case study looks into the consequences of market-driven media-particularly after the Telecom Act. Research is needed into Portland commercial radio for at least three reasons relevant here: its potentially high demand for political information; signs that demand is unmet (or poorly met); and, local broadcasters' concerns that they are unable to fulfill radio's political role. 
Renowned for its public spirit and unique political practices, Portland has demonstrated an appetite for political information. Certainly, with proliferating digital options, information is more available than ever before. But, amid market constraints, serious journalism is increasingly ostracized from mainstream channels, leaving many local radio journalists unable to perform their key political functions: conveying political information, directing attention to important issues, offering a discourse platform. Although the diminishment of news/public affairs has been documented in research into Portland television (Higgins 2005), I have found no such studies on Portland radio-a void this paper seeks to address.

With its populous, liberal electorate Portland has long driven the innovative politics of Oregon — home to the nation's first container-deposit law ("the bottle bill"), one-of-a-kind vote-by-mail system, hyperactive initiative and referendum process, and maverick health plan. ${ }^{16}$ Long known for land-use planning that emphasized farmland preservation and vertical development, the Portland area is in the vanguard of the "green" movement. It ranks with the most bicycle-friendly cities in the world, and recently installed electric vehicle charging stations in multiple locations. ${ }^{17}$ An extensive network of neighborhood associations, a volunteerist ethic, and grassroots activism suggest a robust agenda for public discourse - which, ideally, would be supported by prevalent political information (Sussman and Estes 2004, 136).

However, during the late 1980s and early 1990s in Portland (as elsewhere) civic discourse corroded, with public engagement increasingly characterized by conflict. Although participation in civic associations continued to grow in Portland, bucking a national decline (Putnam, Feldstein, and Cohen, 2003, 243), activists were more often 
rising to challenge collective projects. In contrast to the 1970s, one news content analysis found, two-thirds of 1990s news stories about Portland-area neighborhoods were negative (Johnson 2004, 112). Around this period, Portlanders were shifting their attention away from commercial radio.

Even as newspaper circulation declined, along with network TV news audiences, non-commercial radio greatly expanded its listenership nationwide at the turn of the twenty-first century (Kamenetz 2009; Powers 2003). The decline of news/public affairs on commercial stations may have been a prime reason (Meyer, in Kamenetz 2009). Similarly, while listenership on many of Portland's commercial radio stations dropped during the same period, the city's major non-commercial station, (political informationrich) KOPB, significantly increased its audience share in the post-Telecom Act period. At the precise historical moment when commercial stations were shrinking news/public affairs, KOPB's market ranking rose dramatically—-from around tenth place in the late 1990s, to consistently first or second in 2001 and thereafter (see Appendix L).

Public radio listeners, from market to market, are consistent in what they seek when they tune in public radio: depth, intelligence, authenticity, civility, and a global perspective (Sense of Place 2006). Hence it is reasonable to suspect some Portland listeners departed commercial radio in search of political information. If true it may indicate local commercial stations were not meeting, or were poorly meeting, the informational needs of communities they were licensed to serve (their historical fiduciary obligation).

The final impetus for an examination of Portland commercial radio is the concern of broadcasters themselves. As indicated in the Radio Survey 2011, a component of this 
research project, strong majorities of local broadcast journalists responding felt commercial stations had reduced their news/public affairs content "in recent years," believed "not enough" was currently provided, and found that journalists' "ability to communicate important news subjects" to their listeners was "limited in the current media environment" (Appendix F, questions 4, 5, and 14). Combined, Portland's active, innovative political culture, along with signs that local commercial radio may inadequately provide political information, and the concerns of broadcast journalists make the Portland radio scene ripe for academic study.

\section{B. The Research Question}

This study examines the degree to which consequences of the Telecom Act (consolidation, lost jobs, and diminished news/public affairs) can be demonstrated in Portland commercial radio. Comparing the traditional provision of local news/public affairs with what remained following the Act, I link the Act with lost democratic opportunities. Thus, simply stated, my research question was: What impact did the 1996 Telecom Act have on radio news/public affairs in Portland, OR, and why does it matter? To consider what has already been studied in other media and other markets, I turn to the relevant literature.

\section{The Literature}

Many scholars have examined post-Act radio ownership concentration, but few have documented the Act's impact to radio news/public affairs nor zeroed in on particular markets. While more than 90 percent of Americans listen to the radio (Radio Today 2010), I could find only one study that specifically analyzed local radio news content after the Act. ${ }^{18}$ Conclusions from the relevant literature fall roughly into three broad 
claims: that the Act's dramatic lifting of ownership limits led to voracious consolidation that created radio giants, often distancing owners from their communities; that throngs of broadcast journalism jobs were eliminated; and that station programming lost its local flavor and much (in some cases all) of its news/public affairs. (You may wonder how, if such content has been severely understudied, this third claim can be sustained. As we will see, it is largely based on findings related to jobs, anecdotal accounts, and shared-content data.)

\section{The First Claim: Fewer Owners Nationwide}

The first claim, that rapid consolidation followed the Act, is uncontested. ${ }^{19}$ By 2002, even though the number of radio stations nationwide had increased by 5.4 percent, the number of owners had declined by 33.6 percent (Prindle 2003, 14 n12). Whereas media companies had been limited to owning no more than 40 stations before 1996, the Act's removal of any national cap led to radio behemoths (Bednarski 2003). The ink was barely dry on the Act when radio deals began at a dizzying rate (Rathbun 1996), and within five years the largest, Clear Channel, had gobbled up more than 1,200 stations (DiCola 2006b, 13). ${ }^{20}$ As Boehlert (2001) explained, those stations had previously belonged to 70 separate broadcast companies. As the former head of PBS and NBC saw it:

What once was an industry dominated by locally owned and operated stations and three national radio networks is now an industry dominated by three giant corporations, each of which owns multiple stations in a number of markets, and owns and programs hundreds of radio stations throughout the nation. (Grossman, in Pew, 2004) 
The density of radio concentration led one researcher to observe, "The majority of local radio markets have levels of concentration that ordinarily give rise to antitrust concerns about excessive market power" (DiCola 2006b, 68). Arbitron, the radio rating service, attributed the industry's "unprecedented double-digit revenue gains," from 1998 to 2000, to consolidation: "With the loosening of national and local ownership caps in 1996, groups have discovered how to leverage market clusters" (Radio's Leading Indicator, $2005,4)$.

\section{The Second Claim: Jobs Wiped Out}

The Act promised telecommunications reform that would lead to “competition...private investment... and universal service." Moreover, it heralded untold new jobs (Boehlert 2001). Industries, including phone providers, TV and cable, predicted the Act would add 1.5 million jobs and boost the economy by $\$ 2$ trillion. (Who could doubt reform was in order after 60 years? The Communications Act of 1934 was still in

effect.) By 2003, however, the market value of telecom companies had fallen by about $\$ 2$ trillion, and they had shed about half-a-million jobs (Wexler 2005, 3).

The outcome was, as noted above, severe in the case of radio. So intense was ownership contraction, one Clear Channel executive estimated the Act had erased 10,000 radio-related jobs (Boehlert 2001). Another, more rigorous, assessment found that "the employment of news reporters declined by 56 percent, and employment of broadcast technicians by 30 percent," between 1996 and 2003, "in an average market" (DiCola 2006a, 23).

A now-famous story of near-disaster in North Dakota raises the prospect of serious potential consequences where too few humans staff radio stations. So drastically 
had Clear Channel cut staff at its Minot cluster of six stations, no one answered the phone when police called to announce an emergency: a freight train had derailed, releasing a deadly cloud of anhydrous ammonia (Staples 2003). Equally concerning was word from Harrisonburg, Virginia that four hours passed after the September 11, 2001, attack before Clear Channel's automated group of stations stopped playing music and began broadcasting news (Dotinga 2002). Employees “couldn’t figure out how to do anything because they had so few people in that building" (Prindle 2003, 347 n290).

\section{The Third Claim: Diminished Local News/Public Affairs Nationwide}

A decline in local news/public affairs impacts its important agenda-setting role in facilitating political processes. By directing citizens' attention to issues of public concern local programming fulfills its "best established political role of journalism." But, "tabloidized" local news means serious journalism, "as we have known and valued it," may be relegated to "elite... small taste culture," at the risk of removing it from the genuinely mass media (Swanson 2000, 412).

One indication this has already happened, to a degree, following the Telecom Act is the notable shift to public broadcasting. In a decade, from 1999 to 2009 (years during which the Telecom Act transformed the radio landscape), the audience for National Public Radio (NPR) doubled, reaching an audience of 26.4 million listeners weekly—far more than USA Today's 2.3 million daily circulation or FOX news' 2.8 million prime time audience (Kamenetz 2009). While it barely needs mention that the NPR audience is largely "white, liberal, educated, elite," by NPR's own estimation, it serves only about 11 percent of Americans (AIR 2011). The sudden swell in NPR listenership following the Act suggests a significant desire for political information was not being met by 
commercial broadcasters, and it offers support for Swanson's thesis (2000) that diminishment of local news/public affairs on commercial stations contributes to an antidemocratic class division of political information distribution.

Of the three claims, diminished local news/public affairs is the most difficult to substantiate, not least because of its amorphous nature, conflicting interpretations of localism (geographic versus content-based) ${ }^{21}$ and the dearth of studies into radio content. An FCC study—-published under pressure—into television programming found local owners produced several more minutes of local news than distant owners because of certain incentives: proximity to events, local advertiser satisfaction, and personal localowner interests. ${ }^{22}$ If radio owners respond to the same incentives, it stands to reason they would produce more local news/public affairs.

One detailed project indicated post-Act damage to local radio news/public affairs in Salt Lake City. Sanders (2007) found local owners far outpaced those of distant centralized providers in their commitment to producing and programming local news. Bonneville, the primary local owner, "employed more workers, with more experience in the industry and in the local market," and gave its news people "the most modern [production] equipment and studio facilities." Quantitative data found Bonneville and another, smaller local Salt Lake owner producing more news minutes in every format category, with large national owners offering the least (Sanders 2007, 178).

Many rely on jobs data to demonstrate that news/public affairs content was significantly diminished by the Act. Two commentators found thoughtful, institutional radio news reporting, a staple of 1960s-70s journalism (when all AM and some FM 
stations had news directors and reporting staff), had "all but disappeared" after the Act (McChesney and Nichols 2010, 16).

Figure 1.

THE CRISIS IN JOURNALISM

- 17 -

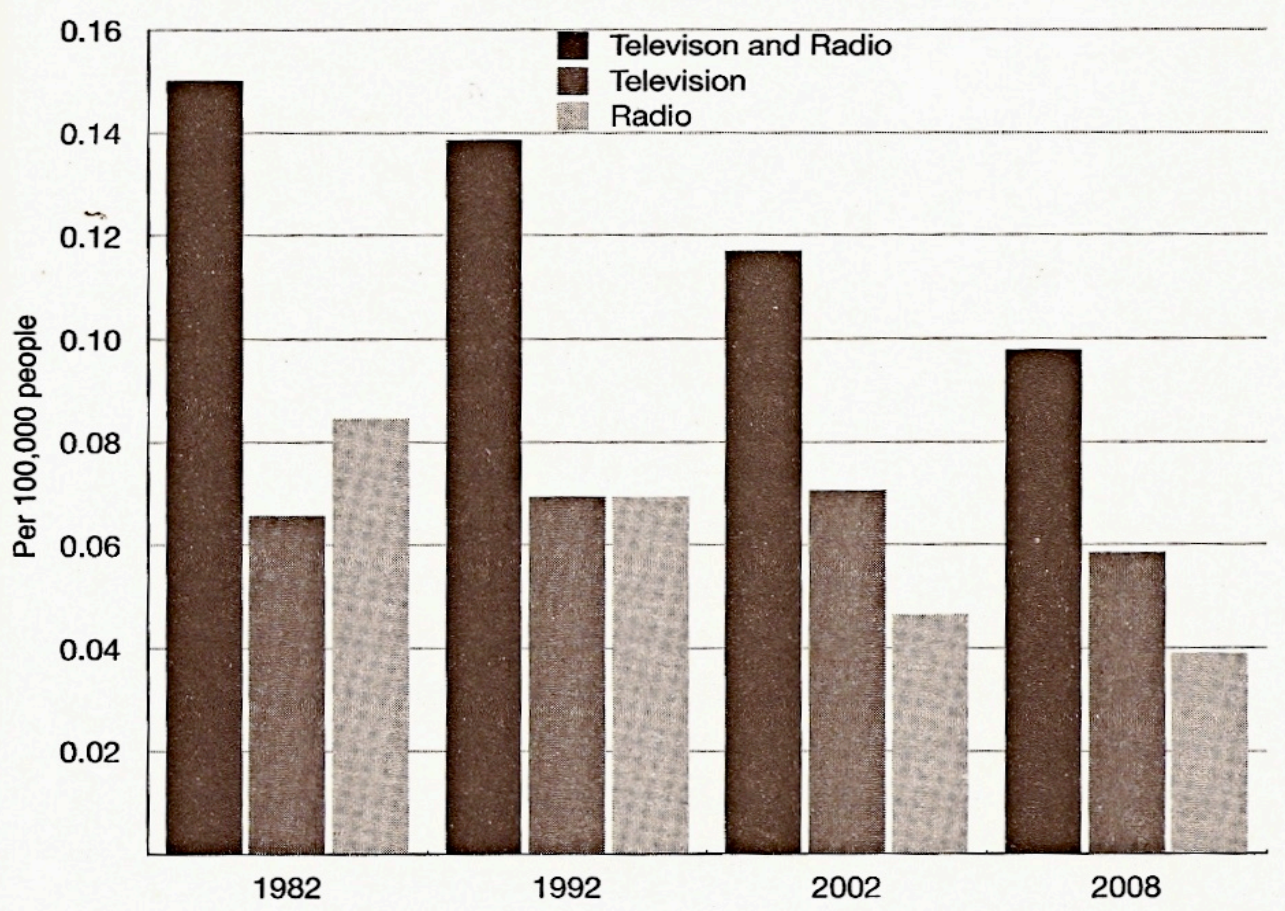

CHART 1. Estimated Workforce in Radio and Television Broadcast News Per 100,000 People, Selected Years 1982-2008 ${ }^{20}$

Source: McChesney and Nichols 2010, p.17.

The McChesney-Nichols chart (fig. 1) shows the decline in broadcast journalism jobs over three decades was especially sharp between 1992-2002, reflecting the Act's impact. Boehlert (2001) also saw jobs lost to the Act as inherently indicative of diminished local news/public affairs: the "near abandonment of local news" (Boehlert 2001).

Bearing out that assertion, the Radio-Television News Directors Association (RTNDA) found (2004) that, increasingly, formats other than all-news were receiving 
program content from "a central news department." A single station was, on average, providing news for three stations (in Pew, 2004). Consolidation proponents point out the new arrangements could have allowed stations previously offering no news to start providing it (in Pew 2004). But, others saw a slide toward "a horror show of packaged homogeneity and cynical, demographic button pushing" (Powers 2004). At the very least, the lost jobs meant fewer local residents were making decisions about what stories to report (DiCola 2006a, 25).

Shared content may also indicate less local news/public affairs, as when announcers "voice-track" content for multiple stations (Silberman 1999). For example, a Clear Channel staffer in San Diego infuses some regional detail into recorded content to make it "seem local" in Boise, Medford, and Santa Barbara. Because a company can utilize the same employee or group of employees to produce content for several markets, fewer content judgments are made locally. On the other hand, Clear Channel contends the technique brings otherwise unaffordable talent into many markets, "a huge benefit to the audience" (Matthews 2002).

All three of these post-Telecom Act claims may have serious implications for democracy. If ownership consolidation (by distancing owners from local concerns) eroded the links between stations and their communities of license, if staff cuts (by eliminating local news judgments) diminished radio's political role, and if shared content (by centralizing programming) limited the number of perspectives, then the Act apparently diminished democratic opportunities. I wanted to gauge the Act's impact in Portland.

\section{Methods}


Informed by scholarly studies and knowledge of the local radio industry, my mixed-design study examined four elements:

1) Station ownership patterns

2) Jobs

3) Public files data

4) Survey of broadcast professionals

I selected six stations that have become local institutions over many years (compare Appendices D and E). Retaining popular appeal and (relatively) consistent formats between 1996 and 2011, my sample stations fall into three station pairs, by owner:

Table 1

\begin{tabular}{|lc|}
\hline OWNER 2011 & STATIONS \\
Clear Channel & KKRZ, KKCW \\
Entercom & KWJJ, KGON \\
Alpha & KUPL, KINK
\end{tabular}

Except in the case of Alpha, the owners had long company histories, enabling the assessment of patterns over time (e.g. employees per station, news/public affairs programming).

For the first element, station ownership patterns, I looked into Arbitron and other $\operatorname{archives}^{23}$ to document the number of stations and owners between 1996 and 2011. Second, to ascertain any decline in jobs, I accessed corporate $10-\mathrm{K}$ and $\mathrm{S}-1$ annual reports from the Securities and Exchange Commission (SEC)—comparing stations owned and staff employed during or near 1996 to the same criteria in $2009 .{ }^{24}$ I should note that this 
finding indicates only overall staff reductions, not specifically news/public affairs jobs. ${ }^{25}$ The third element, public files data, reflected the changed nature of news/public affairs programming. ${ }^{26}$

Finally, I conducted a confidential survey of Portland broadcast professionals associated with a variety of music, news, or news/talk stations. No restrictions (age, gender, ethnicity, experience, etc.) were applied - only the stipulation that respondents worked (or had worked in recent years) in radio journalism. Of surveys emailed to 22 stations or broadcasters I received 17 relevant responses. ${ }^{27}$ Although this is a small sample, respondents serve a broad range of stations and formats, indicated in table 2. Also noteworthy, respondents described their years of experience as ranging from four to 25 years, offering the prospect of both fresh and institutional perspectives. ${ }^{28}$

\section{Table 2. Stations Represented in Radio Survey 2011}

22 invitations were issued to broadcast journalists associated with Portland music, news, or news/talk stations, representing a wide range of formats. 17 completed surveys were tabulated, representing the views of those presently or recently employed at 11 different stations:

KEX 1190 AM (News)

KGON 92.3 FM (Classic Rock)

KXL 750 AM (News Talk)

KPAM 860 AM (News Talk)

KINK 101.9 FM (Album Adult Alternative)

KKCW 103 FM (Adult Contemporary)

KXJM 107.5 FM (Rhythmic Contemporary)

KLTH 106.7 FM (Classic Hits)

KUPL 98.7 FM (Country)

KKSN*

$\mathrm{KOTK}^{*}$

CHR: Contemporary Hit Radio

AC: Adult Contemporary

AOR: Album Oriented Rock

AAA: Adult Album Alternative

*Station has changed formats and call letters since respondent worked there. 
After inquiring in the first questions whether respondents worked in Portland radio news "between 1986 and today," (allowing at least a decade before and after the Telecom Act), and for how many years, I moved on to the substance of the survey: openended questions inviting opinions as to the most "important roles radio should play in a community," whether local commercial radio provided "an adequate source of local news/public affairs," and if not, why respondent thought "stations [had] reduced such programming." Respondents could choose from several possible reasons: ownership efforts to reduce cost; buy-outs by larger media companies; audiences prefer non-news (entertainment); people can get local news elsewhere (TV, Internet, etc.); or, the participant could volunteer some other possible reason.

Then, the following statements were proposed, asking participants to describe, on a scale of one to 10, whether they agreed or disagreed, and how strongly.

\section{Table 3.}

8. Radio is just like any other business, and should be able to profit in the same way as any other business.

9. Because it uses public airwaves, radio is different from other businesses.

10. I think we have plenty of choices for local news/public affairs on the radio.

11. Except for public broadcasting, local radio reporting on important public issues is pretty limited

12. Radio programming should not be regulated. The public interest should be determined only by ratings (how popular a program or station is).

13. Radio stations should be required to air some programs that reflect local concerns.

14. As a broadcast journalist, I feel my ability to communicate important news subjects to my listening audience is limited in the current media environment. 
I also inquired about content sharing among stations, and closed with another essay-style opportunity for participants to offer their thoughts about the "public service responsibilities of local radio." Complete survey text responses are found in Appendix F, highlighted in red.

The Radio Survey 2011 invitation and questionnaire were approved by the PSU Human Subjects Research Review Committee, after it determined there were no ethical concerns. Based on the survey, and the other research elements listed above, I offer this Portland assessment as a supplement to the ongoing inquiry into the impact of media policy on ownership concentration, jobs, and radio news/public affairs. First, a historical perspective on radio's role as a mediator of the public sphere. 


\section{Part III. Historical Perspective: The Public Sphere and Radio}

A strictly economic language functions to distort, perhaps even obliterate, specifically public concerns that remain silent while corporate priorities hold sway.

Carl Boggs, 2000

\section{A. The Public Sphere}

From the Athenian Pnyx to the Roman Forum, civil decision making has taken place in some public realm. And, while the logistical limitation of conducting democracy face-to-face was somewhat overcome with the advent of representative government, "to surmount it completely required the press." Always a necessary component of the "physical conditions for the formation and propagation of public opinion," the newspaper has, through time, comprised that forum for public decision-making (J. S. Mill [1859] $1998,210)$.

Similarly, in America, as Tocqueville famously described, town meetings were arenas of local civil association, fundamental spheres of democracy: places where people came together to exchange information and discuss/promote their ideas. But, what made "political life circulate to every corner of this vast land," was the press (Tocqueville [1835] 2003, 217). This public space, where prevailing opinion developed to influence governing policy, theoretically gave the large and expanding country the capacity to live up to its name: (demos, people + kratia, rule) government by the people. ${ }^{29}$ And, because technological advances made it possible, mass communications have become the modern public sphere (Habermas 1962). Each new form of communication, first newspapers, then broadcast, and now the Internet, mediates the realm where citizens turn their attention (or tune in) to information and ideas. According to democratic theory, public opinion bubbles 
out of this sphere of public discussion and, through representatives in government, informs public policy.

\section{The Press as Mediator of the Public Sphere}

Since media entities facilitate the public discourse crucial to self-governance they are assigned special significance beyond that of mere market participants. If a television, for example, were just a toaster with pictures, as FCC Chairman Mark Fowler suggested (Nossiter 1985), economic logic would treat it like other consumer products. But, because electronic communications devices, unlike toasters, have tremendous potential to shape thought and opinion, their utility to society is not limited to an economic context. Rather, the news media (by definition) mediate $e^{30}$ between citizens and government, circulating (sometimes vital) information. Without this communication neither citizens nor officials would be able to carry out their constitutionally presumed roles in the policymaking process. But, because the Constitution ascribes no institutional role for the press, its function as a component of the American democratic system has been (and remains) the subject of much debate.

Although media are sometimes conceived as an institution, even a fourth branch

of government, ${ }^{31}$ political scientists have struggled to characterize the political role of the press because "the news media are less formally constituted and less bounded" than the institutions political scientists customarily examine. Drawing from behavioralist, sociological, and political science threads, Cook (2005a) finds institutions and media have much in common: they both emphasize accepted rules and routines that have developed over time and across organizations, and preside over a central part of social 
and political life (Cook 2005a, 13, 66 - 71). Hence news organizations, however diverse, comprise an American institution, albeit a controversial one.

Research $^{32}$ indicates that media are a de facto extension of governmentsomething Walter Lippmann observed, with disapproval, in 1922 (in Graber 2007), and a phenomenon that grew in the 1960s with diminishing political party influence (Patterson 1994). Despite the amorphous nature of news and its purveyors, construing the press as a political institution implies a debt to the public interest. Noting in a 1974 speech, for example, that the press was the lone private business singled out for specific constitutional protection, Justice Stewart concluded the First Amendment was designed "to create a fourth institution outside the Government as an additional check on the three official branches" (in Cook 2005a, 178). But, pinning down specific obligations that accompany such responsibility has been complicated, in part because of diverse Court rulings.

\section{The First Amendment: Multiple Views of Press Freedom}

\section{a. The Watchdog}

In its attempt to assess the constitutionality of various news media practices the

U.S. Supreme Court has affirmed multiple conceptions of press freedom, ${ }^{33}$ especially the watchdog and marketplace of ideas models. As Justice Black explained, quoting Madison, the First Amendment was intended to curtail the power granted to the controversial central government in the original Constitution. "The people shall not be deprived or abridged of their right to speak, to write, or to publish their sentiments; and the freedom of the press, as one of the great bulwarks of liberty shall be inviolable" (Madison 1789) ${ }^{34}$ It was the "paramount" responsibility of a free press to "prevent any 
part of the government from deceiving the people," Black declared, aligning himself with the watchdog conception of the press. ${ }^{35}$ Douglas concurred, pointing out that the press clause of the First Amendment ("Congress shall make no law...abridging the freedom...of the press") ${ }^{36}$ leaves "no room for government restraint." The Amendment's "dominant purpose," Douglas found, was to prevent the government from suppressing or punishing the "dissemination of material that is embarrassing to the powers-that-be.",77 And Justice Stewart (joined by White), concurring, also saw the Amendment as a shelter for government critics:

$[T]$ he only effective restraint upon executive policy and power in the areas of national defense and international affairs may lie in an enlightened citizenry - in an informed and critical public opinion which alone can here protect the values of democratic government. For this reason, it is perhaps here that a press that is alert, aware, and free most vitally serves the basic purpose of the First Amendment. For without an informed and free press there cannot be an enlightened people. ${ }^{38}$

With that, Stewart established himself as a key spokesman of the watchdog theory. ${ }^{39}$

But even concurring justices in that famous case (in which the Nixon administration sought to stop the publication of leaked Pentagon documents) had nuanced readings of the First Amendment. Justice Brennan, for example, agreed there could be no injunction against publication —except when, in wartime, the release of strategic information might imperil troops. And, since the Pentagon documents in question were historical (void of ongoing operations detail), Brennan announced (recalling Schenck 1919, and Near 1931) the "chief purpose" of the First Amendment was to prevent prior restraints on publication. ${ }^{40}$ But, though some consider "the Pentagon Papers case" to be the strongest Court statement to date on press freedom (Epstein and Walker 2010,302), three justices dissented. 
Justice Burger, rejecting an "absolute" view of the First Amendment, found "the imperative of a free and unfettered press comes into collision," at times, with "another imperative, the effective functioning of a complex modern government... and powers of the Executive." Echoing that concern with constitutionally granted executive authority in the "field of foreign affairs," and commenting on the historic speed with which the Court issued a short "per curiam" opinion (four days), Justice Harlan dissented, calling the Court “almost irresponsibly feverish.” Justice Blackmun, also dissenting, agreed, pointing out a replacement for the Near test had yet to be "properly developed." Although the Court is often even more divided than in this 6-3 decision, New York Times v. U.S. exemplifies the degree to which judicial authorities differ on the meaning of press freedom.

\section{b. The Marketplace of Ideas}

Well before the Pentagon Papers case, and long since, theories have proliferated as to the scope and purpose of the First Amendment. As is well-known, the marketplace of ideas (associated with Justices Holmes, Black, Brennan, and Judge Learned Hand), holds that a plethora of ideas naturally filter toward the best. Though Holmes introduced the marketplace theory to America, the belief that superior thinking would emerge from uninhibited, robust debate dates back (at least) to Milton and J. S. Mill (Ingber 1984, 3). As Brennan summed up (1964), drawing from famous cases, the First Amendment attempts to secure "the widest possible dissemination of information from diverse and antagonistic sources;" ${ }^{42}$ it is "fashioned to assure unfettered interchange of ideas for the bringing about of political and social changes desired by the people;" ${ }^{43}$ it "presupposes that right conclusions are more likely to be gathered out of a multitude of tongues." ${ }^{44}$ The 
nation's profound commitment to "uninhibited, robust, and wide-open" debate "may well include... sometimes unpleasantly sharp attacks on government and public officials" (in Cook 2005b, 4). Even erroneous statements made, inevitably, in the unfettered exchange of ideas, must be protected to provide the "breathing space" needed by the marketplace of ideas. $^{45}$

Since no objective truth exists, however, critics point out that "truth" is subjective and created. Perceptions of truth would thus vary according to social circumstances and power relations among groups. Hence, as Baker argues in his "market failure" model, the marketplace of ideas is inherently biased in favor of presently dominant groups (Baker 1977).

\section{c. Hybrid Conceptions: Public Deliberation, Self-realization}

Along with the watchdog and marketplace three other related interpretations of the First Amendment should be mentioned: A hybrid of the marketplace and watchdog (linked to Thomas Emerson) predicts robust debate in pursuit of truth will improve government and thus society (Ingber 1984, 4). And, the closely related self-realization theory (launched by Justice Brandeis (following Madison), and developed by Baker, Emerson, Redish) holds that the ultimate purpose of government is to further individual self-development, facilitated by free expression (Stern 1990, 927). Sunstein has crosspollinated elements of Madison, Brandeis, and Alexander Meiklejohn and distilled from them a public deliberation model, which prizes both political equality and a shared civic culture, and seeks to promote "reflective and deliberative debate about possible courses of action (Sunstein 1997, 169). 
Those who won our independence believed that the final end of the state was to make men free to develop their faculties; and that in its government the deliberative forces should prevail over the arbitrary. They...believed that freedom to think as you will and to speak as you think are means indispensible to the discovery and spread of political truth; that without free speech and assembly discussion would be futile; that with them discussion affords ordinarily adequate protection against the dissemination of noxious doctrine; that the greatest menace to freedom is an inert people; that public discussion is a political duty... (Brandeis 1927) ${ }^{46}$

If Brandeis, Black, Douglas, Stewart, Brennan, Holmes, and Hand, along with Milton, Mill, Madison, Emerson, Meiklejohn, Redish, Baker, and Sunstein are all correct, citizens who may speak freely have abundant opportunities to develop their faculties, flesh out the truth, and live under laws and leaders of their own choosing. Difficulty arises, however, in sorting though when and if such pursuits may be abridged, and which are crucial to self-governance—and thus may not be (Meiklejohn [1948] 1960).

\section{Public v. Private Speech}

The broad range of free speech theories is a fertile backdrop for a broadcast media marketplace, where purveyors of information products have held up the First Amendment against government attempts to control their programming. This defense adopts the popular idea that regulation of speech is inherently an infringement of speech, an unauthorized government intrusion into a person's (or broadcaster's) right to speech protection under the First Amendment. This is, according to the Court, a fallacy.

Unlike print media (produced using privately owned equipment), TV and radio stations (operated using publicly owned airwaves, not available to all) are subject to public oversight:

[T] he people... retain their interest in free speech by radio and their collective right to have the medium function consistently with the ends and purposes of the First Amendment. It is the right of the viewers and 
listeners, not the right of the broadcasters, which is paramount... It is the right of the public to receive suitable access to social, political, esthetic, moral, and other ideas and experiences which is crucial here. That right may not be constitutionally abridged either by Congress or by the FCC. ${ }^{47}$

Although some analysts have interpreted speech protection as foreclosing substantive media regulation (Fowler and Brenner 1981), others contend Amendment doctrine “permits non-suppressive, content-based regulation” (Mangarian 2008, 849, n22). Because the argument herein alleges a failure of the market model to provide adequate local news/public affairs programming, it is useful to clarify what is public and what is private, an important distinction for programming media "in the public interest," ${ }^{, 48}$ and a concern that long predates broadcasting.

Chief Justice Waite, for example, affirmed state power to regulate even private property on behalf of the public good, when he upheld grain elevator rates.

Property does become clothed with a public interest when used in a manner to make it of public consequence, and affect the community at large. When, therefore, one devotes his property to a use in which the public has an interest, he in effect, grants the public an interest in that use and must submit to be controlled by the public for the common good... (Waite 1877, in Rainey 1993, 283) ${ }^{49}$

Even conservative Justice Field, although dissenting, saw public interest regulation as constitutional in certain narrowly defined circumstances — such as when "some right or privilege is conferred by the government or municipality," or where the government's action renders "the use of his property...more valuable to him, or [where] he thereby enjoys an advantage over others" (Field 1877, in Rainey 1993, 283).

Licensing broadcasters to use the public airwaves is, since not available to all, a privilege granted to a trustee. Frequently, too, are broadcasters' private properties (e.g. 
capital value of their stations, copyrighted products) made more valuable to him/her by virtue of that government license. And, since broadcasting a message to a mass audience is inherently more influential than shouting from a street corner, the broadcaster has a clear advantage over others wishing to convey an idea. Although developed within the legal realm concerned with economic property rights (rather than liberties of expression) the logic from both sides in Munn serve as useful "historical analogues" for the imposition of public obligations in electronic media (Rainey 1993, 282-84). If anything, economic liberties jurisprudence may gain greater relevance as the market model is increasingly emphasized in broadcast deregulation. And, it is the crux of the public/private speech distinction to which I now turn.

Out of the doctrinal ferment over free expression, Meiklejohn (1948) distilled two kinds of speech, public and private — only one of which is constitutionally sacrosanct.

[The First Amendment] has no concern about the 'needs of many men to express their opinions.' It provides, not for many men, but for all men. ...It cares for the public need. And since that wider interest includes all the narrower ones...it is prior to them all. The public discussion of it, therefore, has a constitutional status which no pursuit of an individual purpose can ever claim. It stands alone, as the cornerstone of the structure of self-government. (Meiklejohn 1948, 55)

The nature and context of rights groupings in the Constitution show that while public speech must be unfettered, private-purpose speech may be constitutionally restrained. For example, public rights are addressed in the First Amendment, while private liberties are covered in the Fifth. Evidently, the "liberty" of speech (which is subject to abridgement, with due process) is "correlated, in the Fifth Amendment, with our [private] rights to 'life' and 'property'...individual possessions." As with many forms 
of individual action and possessions, private interests are "protected by the Constitution—-not from regulation, but from undue regulation..." (Meiklejohn [1948] $1960,36)$.

The constitutional status of a merchant advertising his wares, of a paid lobbyist fighting for the advantage of his client, is utterly different from that of a citizen who is planning for the general welfare. And from this it follows that the Constitution provides differently for two different kinds of 'freedom of speech.' (Meiklejohn [1948] 1960, 37)

What then of the needs of many men to express their opinions? If Meiklejohn is correct, the arguments of profit-oriented media (that they should be free of government mandates) would apparently have more validity framed within the due process context of the Fifth (and Fourteenth) Amendments than behind the free expression shield of the First. As Barron (1967) saw-along with Meiklejohn, and Justices Black (1945) and White (1969) — rather than "a lock that safeguards the market-derived expressive prerogatives of powerful media corporations," First Amendment speech protection was "a key, designed to open public debate to the diverse range of participants and ideas necessary for our democratic system to flourish (Mangarian 2008, 847).

\section{B. Radio}

Among modern mass communications, radio stands out as a significant—but perhaps under-appreciated - contributor to the public sphere because of its easy accessibility, low cost, and pervasive penetration. People spend more time listening to news on the radio each day than they do reading newspapers or getting news online (Olmstead 2011, Audio Essay). Although a majority of Americans cite television as their primary news source, more than ninety percent say they listen to radio in homes, cars, or 
offices. The sharp increase in public radio audiences since the 1996 Telecom Act indicates a demand for informational content (Powers 2003).

Moreover, while new media (e.g. satellite radio, digital devices, the Internet) have otherwise devoured a slice of the traditional media pie, radio has been somewhat impervious to its digital competition. ${ }^{50}$ Thus, regardless of whether listeners are seeking content, they are receiving information that has the potential to weigh on individuals' decisions about public life. The ubiquity of radio gives rise to questions about what messages listeners are receiving, from what sources, and to what effect. These issues have driven both the exploitation of radio as communications medium, and government policy regulating its use.

\section{Radio: Historical Perspective}

The story of radio began with tinkerers, sailors, educators, and entrepreneurs, until a Marconi operator stunned the world with news of the Titanic disaster, drawing the interest of giant corporations. ${ }^{51}$ General Electric (GE) joined American Marconi to form the Radio Corporation of America (RCA), soon adding American Telephone and Telegraph (AT\&T), which held a needed patent. Once its sole remaining large-scale competitor set off a national mania for radio sets (by broadcasting the Harding elections returns in 1920), RCA took in Westinghouse - creating by 1921 a powerhouse that owned all the patents (two thousand of them) needed to dominate the future of broadcasting (Barnouw 1966, Rosen 1980).

"We will maintain them [radio activities] free-free of monopoly, free in program, and free in speech..." declared Commerce Secretary Herbert Hoover, who claimed (1925) government oversight would ensure attention to the public interest. ${ }^{52}$ But, in fact, 
Hoover, urged by industry leaders at the first Radio Conference (1922), had already assigned a limited number of the most desirable wavelengths to "an aristocracy of wellfinanced stations," giving them strength to influence policy (Barnouw 1966, 94, 100).

Although Congress had directed the Federal Trade Commission (FTC) in 1923 to investigate whether RCA constituted a monopoly, there was no public hint of anti-trust concern as RCA debuted the first National Broadcasting Company (NBC), attended by captains of industry and finance (1926). The New York gala was followed by a rapid sequence of significant events: passage of the 1927 Radio Act, the dropped FTC investigation (1928), and Hoover's election (1928). His presidential acceptance speech (1929) was carried by 107 NBC and CBS stations (Barnouw 1966, 173, 201, 233).

In 1928, 732 stations, many independent of the networks, held licenses. Often publicity vehicles for newspapers and businesses, the independents were a diverse group - including WCFL, a Chicago labor station, and WEVD, in New York, named for socialist Eugene Victor Debs. Scattered religious stations were on the air, along with educational studios that offered "concerts, talks, including full college courses." To clear up interference, however, the Federal Regulatory Commission (FRC) announced the ranks had to be thinned by at least 100 stations. Since the FRC relied on technical superiority to determine survivors, educational stations and other non-profits operated from classrooms or basements were vulnerable. While a full accounting of all the independents is outside the realm of this paper, of 151 educational stations licensed by then, 24 remained in 1933. (Barnouw 1966, 173, 209). Thus began radio broadcasting "in the public interest."

\section{Radio Regulation: Underlying Principles}


Although elusive, officials have relied largely on two Court decisions to

determine what the public interest entails. In $N B C$ v. U.S. (1943), ${ }^{53}$ the Court determined the policy goals of competition and localism fell within the scope of the public interest. Combined with language from AP v. U.S. (1945) ${ }^{54}$ two years later, insisting that the "dissemination of information from diverse and antagonistic sources," serves the public interest, Congress and the FCC have interpreted the public interest as requiring promotion of "competition, diversity, and localism" (Prindle 2003, 280). But, as Napoli (2003) explained, those vehicles derive from the foundational marketplace of ideas.

\section{a. The Marketplace of Ideas}

First invoked in American jurisprudence by Holmes (1919), ${ }^{55}$ as noted above, the idea marketplace serves media policy as a dual-purpose metaphor: for democracy, in which free-thinking citizens ideally inform and govern themselves; and economy, wherein productively managed resources maximize economic efficiency and consumer satisfaction (Napoli 2003, 24, 97). Stemming from the marketplace are other key media policy goals closely linked with democratic theory: diversity, competition, universal service, and, localism.

\section{b. Diversity, Competition, Universal Service}

Diversity goes beyond the mere number of marketplace participants (which counts competitors) to the characteristics of participants (e.g. minority station owners) and to programming (e.g. variety of viewpoints presented). Competition takes a purely economic approach assessing such factors as market power, barriers to entry, and prices. Universal service - unlike competition, but harmonious with democratic theory - holds that citizens are equally entitled to resources, just as citizen access to news/public affairs 
is crucial to the participation required of democracy (Dahl 1989; Delli Carpini 2000; Dewey [1927] 1954; Meiklejohn [1948] 1960; Schattschneider [1960] 2008). The Court recently upheld aspects of universal service and democratic goals in Turner Broadcasting Sys. V. FCC (1994). ${ }^{56}$

\section{c. Localism}

That local programming was at the core of broadcast policy was confirmed early in legal disputes over regulation. The Court (1943) called local programming "a vital part of community life,,$" 57$ and judged service distribution (1955) as equitable if it provided "a community radio mouthpiece. ${ }^{, 58}$ Presenting "programs of local interest and importance" were "the prime factor" in broadcast regulation, according to the D.C Circuit (1956). ${ }^{59}$ As with the public interest, though, exactly what constitutes localism remains controversial.

The FCC (2004) defined localism as "programming that is responsive to the interests and needs of [broadcasters'] communities of license," ${ }^{, 60}$ but declined to specify the precise meaning of either "programming" or "responsive." Thus some argue that localism is vague, and not historically mandated (Cole and Murck 2007). The U.S. House tried to pin down the meaning (2007), declaring it "local operations, local research, local management, locally originated programming, local artists, and local news and events."

The idea of localism is consistent with our federal political system, which "divides power between a central government and [other] subdivisional governments, giving each substantial functions" (Corwin and Peltason 1997, 17). From schools, parks, and libraries, to soil, sewer, and water districts, to cities, counties, and states, local decisions are made about community resources in which local residents have an interest. 
Hence, broadcast news/public affairs programs emanating from a particular geographic “point-of-origin" were historically presumed to increase station interaction with residents, and result in responsive programming (Napoli 2001, 376). The FCC required, for example, that radio and TV stations locate a studio in the area they were licensed to serve, and originate half of their non-network programming from that studio (Napoli 2001, 378).

An alternative view of localism, one gaining interest in the Internet era, gave more weight to content than geography. Stations were required, for example, to ascertain the top local concerns through surveys, and to produce relevant programs. ${ }^{62}$ Keeping these foundational principles in mind, I summarize regulatory actions during the trustee period of broadcasting.

\section{The Trustee Model}

\section{a. Radio Act of 1927}

The Radio Act of 1927 authorized the FRC to grant licenses for the use of radio channels by "individuals, firms, or corporations, for limited periods of time," when the Commission determined it served the "public interest, convenience, or necessity.",63 Thus, broadcasters were trustees of the public airwaves, upon their pledge to the public interest. But, that mandate was undefined when, in a set of guidelines known as Great Lakes, the FRC infused it with meaning for the first time.

Programming content, the agency announced (1929), should reflect the "tastes, needs, and desires of all substantial groups" within its listening community. The agency also called upon stations to provide "free and fair competition of opposing views" (Rainey 1993, 280). Because it contained the "seeds of concepts that would later germinate" into major policy principles (e.g. localism, ascertainment, the Fairness 
Doctrine), Great Lakes could be considered the FRC's most important policy statement (Smith, Meeske, and Wright, 240).

\section{b. Communications Act of 1934}

To put down a rising tide of criticism over the entrenchment of commercial broadcasters (McChesney 1993), the 1934 Communications Act entailed a compromise: It promised that broadcasters would allow non-profits "access" to their facilities, and that the new Federal Communications Commission (FCC) would study the idea of frequency set-asides for non-commercial uses (Brown 1989, 283). Essentially reprising the 1927 Act, the 1934 statute made just one other significant change. The FRC, a temporary body, was replaced with the permanent FCC, meaning radio issues would undergo less-frequent scrutiny by Congress.

\section{c. 1940s: Chain Broadcasting Rules, Blue Book, Fairness Doctrine}

Increasingly disturbed by the rise of network broadcasting at the expense of eclectic local stations, the FCC determined that NBC should relinquish one of its (Red and Blue) networks. Its Chain Broadcasting Rules (1941) also limited, for the first time, network control over affiliates (e.g. length of contracts, must-carry rules) (Napoli 2003, 210). Deflecting a vigorous challenge from NBC, the Court upheld FCC authority to regulate, affirmed the public interest as the "touchstone" value of regulation, offered a scarcity rationale, and declared that licensing requirements did not violate broadcasters' First Amendment freedoms. ${ }^{64}$

Permitted by that sweeping affirmation, the FCC issued (1946) an outline of how stations could demonstrate that their licenses should be renewed. In a staff report nicknamed the "Blue Book," the agency suggested stations carry more: sustaining 
(unsponsored) programs, local live programs, local public issues discussions, and less advertising. Since never adopted nor repudiated, these guidelines-emphasizing the importance of local productions - remained suggestions (Krasnow and Goodman 1998, $611)^{65}$

That radio stations were expected to take an even-handed approach was more assumed than promulgated in policy until The Mayflower Doctrine (1941) held that:

Radio can serve as an instrument of democracy only when devoted to...the exchange of ideas fairly and objectively presented. A truly free radio cannot be used to advocate the causes of the licensee. It cannot be used to support the candidacies of his friends...In short, the broadcaster cannot be an advocate. ${ }^{66}$

Dissatisfaction with this apparent ban on editorializing led to the Fairness Doctrine (1949). Instead of prohibiting editorials, the new doctrine called for a "fair and balanced presentation of differing viewpoints" on controversial issues. ${ }^{67}$ Contending the mission "of mass communication in a democracy [was] the development of an informed public opinion through the public dissemination of news and ideas concerning the vital public issues of the day," the Fairness Doctrine was central to broadcasting regulation under the trustee model and was upheld in Red Lion v. FCC (1969) ${ }^{68}$ (Rainey 1993, 302 n1).

\section{d. 1950-70s: Ascertainment}

After hearings on the quiz show scandals of the late 1950s, the FCC determined that broadcasters' responsibilities should be clarified. To that end, it issued the 1960 Programming Policy Statement listing fourteen "major elements usually necessary to meet the public interest," ${ }^{, 69}$ (see Appendix A). Of the highest priority were programs 
offering opportunities for "local self-expression" and "development and use of local talent."

But a new and controversial element in the 1960 Statement directed licensees to discover the "tastes, needs, and desires" of their listeners (reiterating the language from Great Lakes) through surveys of community leaders and the general public. Although some broadcasters objected to this ascertainment of local concerns through surveys, the D.C. Circuit upheld it. The court found Suburban Broadcasters, whose owners did not reside in Elizabeth, New Jersey, had made "no inquiry into the characteristics or programming needs of that community," and whose application, in fact, was "identical" to those Suburban had submitted in Berwyn, IL, and Alameda, CA. As Judge Bazelon put it, "Communities may differ, and so may their needs." ${ }^{, 70}$ Several years later, the FCC added that, along with ascertaining local concerns, the licensee was expected to offer programs addressing those concerns. ${ }^{71}$ Thus into the 1970 s ascertaining and formulating programs responsive to local needs was elemental to the public interest, but this would soon change.

\section{The Market Model}

Famously describing television as a "toaster with pictures" (Nossiter 1985), Reagan-appointee Mark Fowler led the drive to do away with the trustee model. Claiming regulatory processes infringed on broadcasters' First Amendment rights, Fowler announced "long overdue" the abandonment of the scarcity rationale on which the trustee model of licensing had long been premised.

Whether you call it "paternalism" or "nannyism -- it is "Big Brother," and it must cease...Under the coming marketplace approach, the Commission should as far as possible, defer to a broadcaster's judgment about how best 
to compete for viewers and listeners, because this serves the public interest. (Fowler 1982, 213)

Invoking Adam Smith, Fowler declared, "consumers are best off when...resources are allocated" such that people may "satisfy their wants as fully as possible" (Fowler and Brenner 1981, 210). Under Fowler's leadership, the FCC agreed competitive market forces, rather than regulatory mandates, would more effectively serve the policy goal of generating locally relevant programming. To that end, the FCC implemented new policies.

\section{a. Most Rules Eliminated}

In a fell swoop, the Fowler FCC abandoned (1981) many radio policies that had been promulgated over decades. Overturned were procedures for ascertaining community concerns, limits on advertising, program logs, and requirements for non-commercial programming. ${ }^{72}$ Saying Congress had authorized it (1934) to act in the public interest, "We conceive of that interest to require us to regulate where necessary, to deregulate where warranted, and above all, to assure maximum service to the public at the lowest cost and with the least amount of regulation and paperwork" (in Krasnow and Goodman 1998, 617).

Ascertainment, as Fowler saw it, often amounted to no more than "five-minute interviews with community leaders" that usually produced a "perfunctory list of community needs and of standard programs to fulfill those needs" (Fowler and Brenner 1981, 208-9). Though community needs were still to be assessed, how they were addressed would henceforth be up to broadcasters. Further, in light of technical advances in production and transmission, the Commission concluded there was no "causal 
relationship between the main-studio rules and service to the community of license." Thus, both the (content-based) ascertainment of local concerns through surveys, and the (geography-based) 50\% program-origination requirement were eliminated. And, doing away with the main studio rule, the FCC would now allow broadcasters to operate from anywhere within their "principal community contour," a broader geographic region (Napoli 2001, 378; Rainey 1993, 272).

The FCC also eliminated (1983) several policies admonishing broadcasters to avoid certain dubious programming and commercial practices. These included station personnel conflicts of interest, misleading concert promotions, and the broadcast of false, misleading, and deceptive commercials. ${ }^{73}$ Upholding the Commission's elimination of "underbrush policies," D.C Circuit Appeals Court found the public interest standard was best left to the Commission, if it reasonably found that a "market approach offer[ed] the best means of controlling the abuse," said the D.C Circuit Appeals Court ${ }^{74}$

\section{b. Postcard Renewal Implemented}

Whereas license renewal applications had previously required quantitative data on sample weeks of programming, a new streamlined process would ask only five questions: 1) broadcasters' name and location; 2) whether they had filed annual employment reports; 3) if the station complied with regulations against alien ownership; 4) whether licensee was the subject of any adverse character or conduct findings; 5) and, if public

file documents were up to date. ${ }^{75}$ This process was to be so comparatively simple, the answers could fit on a postcard (Hagelin and Wimmer 1986, 217).

\section{c. Fairness Doctrine Abolished}


Among the most controversial deregulatory actions under the marketplace approach was the demise of the Fairness Doctrine, which had been implemented to ensure a diversity of ideas. Ironically, the same rationale that led to its creation ultimately led to its demise. After the D.C. Circuit accepted broadcasters' claims that the burden of the doctrine had actually discouraged them from taking up troublesome issues, and interfered with their speech protection under the First Amendment, The FCC did away with the policy in 1987 , citing a "chilling effect."76

\section{d. Ownership Limits Relaxed}

Early in the market model's tenure, the FCC began to ease limits on the number of stations broadcasters could own. Heretofore one owner could control no more than seven TV channels, seven AM, and seven FM radio stations (the so-called 7-7-7 rule), but ceilings were raised to twelve (the $12-12-12$ rule) in $1984 .{ }^{77}$ The national ownership cap was again expanded in 1992 to 18 AM and 18 FM stations. Then, as is well known, all restrictions were lifted (1996) on the number of radio stations a single media company could own nationwide. The 1996 Telecommunications Act also raised the lid on the number of local stations a firm could own within a single market - a limit pegged to market size.

\section{Critical Evaluation of Both Models}

While there is much to admire (the trustee model's community ties, the market model's simplicity) both models are flawed. Both models, for example, illustrate the incentive for public officials to defer to broadcasters' interests. Hoover's grant of prime radio frequencies to broadcast behemoths, at the expense of small non-profits, exposed the trustee model's fragile relationship with the public interest. Perhaps as significant was 
Congress' award to (TV) broadcasters: tens of billions of dollars worth of radio spectrum free, at the behest of the National Association of Broadcasters (NAB), the market model's most overt example of media power over officials (Snider 2005). ${ }^{78}$ Senator Bob Dole accused the NAB of "bullying Congress" (Stern 1996). As Senator John McCain put it, the threat of withholding media access or of unfavorable coverage "is an unstated, unspoken message always in the room" (in Snider 2005, 220). So deferential were regulators under the market model, they sometimes concealed their own studies, if those studies suggested policies unfavorable to broadcasters. ${ }^{79}$

Another worry with both models is broadcasters' inducement to secrecy about their influence in policy matters, evident in the lead up to both the Communications Act (1934) and the Telecommunications Act (1996). Despite significant public objection to the original commercialization of radio, there is no evidence any broadcaster opened a forum for public discussion of its merits (McChesney 1993). In fact, broadcasters apparently buried complaints they received (Barnouw 1966, 206). And, although print widely reported the spectrum allocation part of the 1996 Telecom deal as a "giveaway," "the Godzilla of corporate welfare," and "TV's big stick," commercial television avoided mentioning it, in what was criticized by print media as a TV news blackout (Snider 2005, 442). ${ }^{80}$ Moreover, in the debate leading up to its passage, there was almost no discussion of the Act's possible impact on radio. A source familiar with NAB lobby tactics said the group knew to "lay low." Had there had been a separate radio deregulation bill, the NAB insider said, "it wouldn't have passed" (Boehlert 2001).

And, both models rely on advertising which shapes programming in antidemocratic ways — as has been empirically demonstrated since the 1940s. Lazarsfeld and 
Merton put it simply (1948): "he who pays the piper generally calls the tune." They found commercially sponsored mass media avoided minority or critical perspectives (to keep consumers in a buying mood) and thus restrained the cogent development of a genuinely critical outlook. Further, researchers saw audiences narcotized, receiving information but not acting upon it (in Marris and Thornham, 2000, 23).

Because the commodity for sale is not radio programs but the audience's attention (Smythe 1982), and since advertisers seek audiences likely to buy their products, listeners are targeted for their demographic profile (e.g. age, income, profession, educational level, etc.). Waldfogel's “economic theory of discrimination” explains why markets will underserve "preference minorities," small groups with atypical or critical preferences: "The market delivers fewer products - and less associated satisfaction - to these groups simply because they are small." In other words, profit-maximizers "serve the core audience and neglect minorities"- - whether of a demographic or viewpoint (critical) nature. This largest-market-share ethic undercuts broadcast journalists' ability to deliver culturally diverse programming, leading to generalized, homogenized content. ${ }^{81}$

Market pressures unleashed upon radio by the Telecom Act, with their drive toward radical ownership concentration, meant fewer people producing more product.

The economic logic of consolidation is to reduce labor costs by centralizing content production, reducing reporting expenditures, repurposing content across media platforms, and filling the news hole with low-budget content such as coverage of weather, crime, and accidents. Meanwhile, coverage of local politics and elections has reached crisis levels of inadequacy. (Kimmelman, Scott, and Cooper 2006, 17)

By misapplying an economic frame to a public good, the market model stands out as a singularly devastating threat to public discourse. Because news/public affairs products 
are public goods (one person's use or benefit from the item does not affect its use or benefit to others), market incentives are not sufficient to support the discursive structures democracy demands.

"First copy" or upfront costs (creating a media product for the first time) are substantial, and remain the same no matter how many people tune in. Thus market emphasis does not encourage broadcasters to produce thoughtful or investigative (expensive) news/public affairs programming (Baker 2002b, 8). Like clean water or public highways, benefits accrue to society at large ("positive externalities") that are not captured by the market. Investigative journalism, for example, uncovering government waste or a consumer scam benefits "even those who do not read the newspaper or advertise on its pages" (Kimmelman, Scott, and Cooper 2006, 8). As Zaller put it, "For every set of cases in which I am able to make plausible comparisons...market competition [is] associated with lower levels of news quality" (in Fog 2004, 5).

Among the most disturbing market model developments has been the decline of a fairness ethic in broadcasting. While the Fairness Doctrine required broadcasters to "afford reasonable opportunity for the discussion of conflicting views on issues of public importance, ${ }^{, 82}$ the market-model FCC takes a hands-off approach, interpreting the First Amendment to preclude the Commission from "interfering with freedom of expression in broadcasting." Beyond categories of speech the Court has declared unprotected by the First Amendment (incitement to imminent lawlessness, obscenity, child pornography, libel, national security), only deliberate "hoaxes" and the "intentional falsification of the news" will prompt an FCC content review (Media Bureau 2008). Though a full assessment of the Doctrine, and broadcasters' claims of a "chilling effect," is beyond the 
scope of this paper, I argue (with Barron 1967) that it is "impossible to have the system of licensing [in which broadcasters have privileged access to public airwaves] and take the position that the broadcaster can operate in his private interest alone" (in Rainey 1993, 328, italics provided).

Because of their fundamental flaws (privileged, undisclosed broadcaster policy influence; ad-reliance) both the trustee and market models are problematic. But, with its severe indifference to political information, the market model relinquishes any commitment to outcomes not expressed in terms of consumer preferences. Especially in the market model's extreme application, the 1996 Telecom Act, efficiencies unleashed exorbitant deregulation (Howard 1997, 275), leading to historically unrivaled consolidation, which created "industry giants like Clear Channel, with more than 1,200 stations" (Wexler 2005, 5), previously belonging to 70 formerly separate broadcast companies (Boehlert 2001). Although garnering "unprecedented double-digit revenue gains" for the largest radio owners (Radio's Leading Indicator 2005, 4), the post-Act consolidation sacrificed diversity and localism (Prindle 2003), slashed an estimated 56 percent of radio news reporting jobs (DiCola 2006, 23), and, diminished local news/public affairs on commercial radio (Boehlert 2001; Folami 2010). This risks lost commitments to democratic ideals — including fairness - which inhere in the public interest.

\section{Radio's Unique Qualities and Democratic Potential}

Since its emergence, radio has always been uniquely capable of immediate, direct contact with masses of people, free of the "ideological apparatuses" of the state, as Bertolt Brecht put it. And, although radio was never fully implemented as the idyllic two- 
way channel Brecht advocated in his radio experiments of the 1920s, the medium has been a pillar of community building — combining "entertainment and democracy, sound and citizenship" (Hartley 2000, 155). Because of its accessibility, affordability, and ubiquity, radio has been a stage for challenges to the status quo in the U.S. and around the world. The advent of new media does nothing to erase the democratic possibilities of radio.

So accessible, affordable, and potentially pervasive is radio, that it has been a global mechanism for growing civil society. Non-governmental organizations in developing countries, for example, broadcast life-saving information by radio during crises or epidemics. In post-Apartheid South Africa, distribution of wind-up radios facilitated political communication to areas where rural, poor residents had no access to electricity (Inventor 2007). And, for the Aboriginals and Islanders of Australia, low-cost, low-tech radio became a bridge for communities through dozens of local stations "necklaced together" into an alternative broadcast service for indigenous peoples (Hartley 2000).

Even within the commercialized framework of American broadcasting, radio was seen at its emergence as a vehicle through which "marginalized populations could be included in America's democracy by using the expressive and deliberative space" of the airwaves (Folami 2010, 142). Most amateurs, of which there were nearly 15,000 by 1922, frowned on passive listening. "Most of them believed that radio should be an active medium of communication" (Lubar 1993, 214). And, since no natural reason existed, other than political influence, for American radio to be dominated by a few commercial 
broadcasters in the early twentieth century, public dissatisfaction attended the early entrenchment of networks (McChesney 1993, Barnouw 1966).

However, regulatory intervention curtailing network dominance (see Radio Regulation, Chain Broadcasting Rules, 1941) recalled the democratic possibilities of radio. Remotely provided, top-down programming gave ground to formerly marginalized "voices of resistance" to mainstream norms and values. Local disc jockeys, tapping into the longings of "unacknowledged youths" by playing their music on the radio and announcing local events, gave voice to "concerns and interests that were otherwise rendered invisible by dominant media outlets." Especially notable was radio's challenge to mainstream ideologies that prohibited racial mingling — as when Black rhythm and blues infused White rock and roll in the late 1940s and 1950s (Folami 2010, 145).

Compared to print, television, and the Internet, radio is more accessible, userfriendly, and is complementary to other activities. If staffed by local employees, radio can convey immediate, local, widely dispersed information (whether entertainment, emergency, or political) with timeliness and penetration unrivaled by more cumbersome media forms. Moreover, because it "spares its listeners and performers from distracting visual artifices," radio can be a more "contemplative medium" that invites "greater imaginative and intellectual involvement" than television (Sussman 1997, 94).

In light of the historical role ascribed to the press, which today includes electronic media, and the special qualities of radio (capacity for immediate, direct contact with publics - local, remote or disenfranchised; accessibility, affordability, ubiquity, simplicity), radio can make a distinctive contribution to news/public affairs. Rather than merely serving almost exclusively as profit centers for large corporations, radio stations 
can perform an essential political role — often more effectively and democratically than other media. And, as I show in part IV, Portland stations often routinely carried out such a role — even, to some extent, under the early market model — prior to the Telecom Act. With an ear toward citizens' concerns arising from the Habermassian wild complex (mentioned in part II), radio can mediate the information flow between citizens and their representatives. It can direct public attention to important issues, and foster opportunities for citizens to act in concert by publicizing their projects. It can inform and engage listeners, enhancing their political resources, and thus their chance of equal consideration in the distribution of societal goods.

This section supports the second underlying premise of my paper: when linked to communities through local news/public affairs, radio's contribution to democracy is unique. Hence I am suggesting that the removal of public interest safeguards in media policy (which connected radio outlets to local communities) is a loss for democracy-a thick thread snipped from the fabric of local social life. In part IV, I will take up the third premise, that the extreme application of the market model, the Telecom Act, diminished local news/public affairs, and consequently, democratic opportunities for Portland radio listeners.

\section{Why Radio Still Matters in the Internet Era}

Advocates for the market model argue that because consumers have "more choice from more sources" than at any time in the history of communications (e.g. Internet, cable, satellite), worries about the market model and concentrated media ownership are unfounded (Compaine 2005, 1). Under scrutiny, though, this argument is flawed on 
several grounds: namely, the transfer of old-media ownership patterns to new media; limited digital access and efficacy; and, the Internet's atomizing effect.

First, ownership patterns dominant in traditional media have been transferred to the Internet (Napoli 2007, 19). More often than not, people seeking their news online are turning to the Internet version of the same material produced by traditional media sources elsewhere (Blosser, et al. 2007, 8). As the Pew Project found (2010), "80 percent of traffic to news and information sites is concentrated at the top seven percent of sites," and " the vast majority of those sites (67 percent) are still tied to legacy media" (Pew 2010, 3). Thus, even if traditional sources were not sought, they would likely be found, since "Internet sites are aggregators of the news gathered by old media rather than producers of [their own] news content" (McChesney and Nichols 2010, 16).

Second, although great strides have been made in expanding broadband access (Implementing 2011), the Internet is not available to everyone, and most people still rely heavily on traditional media sources (Pew 2010,3). And, even though anyone with access and computer savvy can set up a website and send information to the world, his or her ability to have a message heard, or "enter the public's awareness," is severely limited compared to the relative power of established media (Schwartzman, Leanza, and Feld 2008). Moreover, while the Internet and other digital options have replaced scarcity with relative abundance (Huber 1997, 137), it is still not possible for everyone to broadcast at the same time. Thus entrenched broadcast interests remain at a distinct speech advantage (since more than 90 percent of Americans hear the radio), in violation of the long-held premise that citizens' rights are prior to those of broadcasters' (Cook 2005a, 178). 
Finally, and perhaps most important to democracy, all Internet virtues aside, it "has vices as well."

\begin{abstract}
Although millions of people are using the Internet to expand their horizons, many people are doing the opposite, creating a Daily Me that is specifically tailored to their own interests and prejudices. Whatever the exact numbers, it is important to realize that a well-functioning democracy-a republicdepends not just on freedom from censorship, but also on a set of common experiences and on unsought, unanticipated, and even unwanted exposures to diverse topics, people, and ideas. A system of 'gated communities' is as unhealthy for cyberspace as it is for the real world. (Sunstein 2001, 2)
\end{abstract}

Sunstein's thought experiment in Republic.com (2002), in which everyone has a personal communications universe echoes anti-federalist, Tocquevillian, Deweyan, Delli Carpinian, and others' concerns with community linkage. While increasing the variety of perspectives available, the Internet also offers "unprecedented opportunities to narrow the range of viewpoints one encounters" (Mangarian 2008, 848). The present era of political polarization suggests a need for more - not fewer-opportunities to "act in concert," and to "realize every day [our] mutual dependence." 83 


\section{Part IV. Presentation of the Research: The View from Portland}

Having offered support for this paper's first two propositions (that democracy depends on political information distribution, and that radio can uniquely contribute to that distribution through news/public affairs), I turn to the third premise: that the 1996 Telecom Act specifically impaired local radio news/public affairs. Keeping in mind themes found in the literature (summarized in part II), I searched for comparable Act effects in Portland. If the Act impacted Portland radio as it did stations nationwide, I reasoned, I would find parallel trends: fewer owners, lost journalism jobs, and diminished news/public affairs. Using the research methods described in part II, here is what I found.

\section{A. Fewer Owners in Portland}

Just as the Act prompted sharp ownership consolidation nationwide, similar ownership patterns prevailed in Portland in the post-Act years. As Appendix B shows, 30 different entities owned 40 stations in $1996 .{ }^{84}$ By 2011, though three new stations had entered the market, ${ }^{85}$ the number of owners had declined significantly, to only 21 , a decrease of 30 percent.

Even more striking is the market dominance of just one company, Clear Channel, in Portland. Although 21 Portland owners are licensed in the Portland area, many are small special-interest projects—such as religious or Spanish language stations—enjoyed by a fraction of the audience so small they barely register on ratings charts (See

Appendix C). ${ }^{86}$ By contrast, an examination of the top 12 stations indicates the vast radio terrain now controlled by just a few owners. For example, in 1996-97, the top-rated 12 stations controlling the bulk of the audience were owned by seven different companies (Appendix D). In 2011, only three companies own all dozen top commercial stations 
(Appendix E) ${ }^{87}$ Viewed another way, taking into account only the top five commercial stations, just two owners reign: Not counting the popular publicly owned station, KOPB, Clear Channel owns four of the top five commercial stations - a commanding and highly profitable market position.

Arbitron (2005) points out, "the top five ranking stations [in any average market nationwide] net 39 percent of radio revenues," meaning that "heavy hitters take a disproportionate share of radio revenue" (Radio's Leading Indicator 2005, 10). One study (2003), produced but not released by the FCC's Media Bureau, ${ }^{88}$ found the revenue benefits to market dominance even more pronounced: "[T]he largest firm in each radio metro market has, on average, 46 percent of the market's total radio advertising revenue," and the "largest two firms in each radio market have, on average, 74 percent of the market's radio advertising revenue" (Blevins and Brown 2010, 613). This offers media companies tremendous incentive to form market clusters, as Entercom describes in the jobs section below. In a moment, I examine whether market clusters lead to diminished news public affairs through the use of shared content.

\section{B. Jobs Wiped Out in Portland}

With the dramatic loss (more than half) of radio journalism jobs nationwide (DiCola 2006a, 23), I wanted to gauge jobs lost to the Act in Portland. That turned out to be tricky, since radio employees are frequently jacks-of-all-trades, performing multiple functions. Hence I offer findings, derived from SEC annual reports, which represent employees overall, not just broadcast journalists. Employing two of my station pairs, here is what I found. ${ }^{89}$ 
Clear Channel, which had a national average of 27.6 employees per station nationwide at the end of 1996 , had cut that number to 14.5 employees per station in 2009 , a 47 percent drop since the Act was approved (see table 4). ${ }^{90}$ If Portland's Clear Channel stations are typical, their staffs have been cut by nearly half (see appendix I). If half of radio news jobs nationwide were lost to the Act, it stands to reason a large portion of the wiped out Portland jobs would have been those of journalists.

Table 4.

\begin{tabular}{|lcc|}
\hline \multicolumn{1}{|c|}{ Clear Channel } & Dec., 1996 & Dec., 2009 \\
U.S. Stations & 86 & 894 \\
U.S. Employees & 2,377 & 12,984 \\
Average Employees per station & 27.6 & 14.5 \\
Source: U.S. Securities and Exchange Commission, see n85. & & \\
\hline
\end{tabular}

Entercom demonstrated a less severe decline in the number of workers. With 41 stations in 1998 (the oldest year for which data was available), Entercom employed 684 full-time and 250 part-time workers - a per-station average of 16.68 fulltime and 6.1 parttime employees. ${ }^{91}$ By November, 2009 (with 110 stations), the company employed 1,560 full-time and 750 part-time workers - a per-station average of 14.18 full-time and 6.8 part-time employees (see table 5). ${ }^{92}$ This represents a 15 percent decline in full-time workers, while the use of part-timers went up by 11 percent. (Note that, since KWJJ was not owned by Entercom in 1998, suggested job patterns would not apply.) $)^{93}$ 
Table 5.

\begin{tabular}{|c|c|c|c|}
\hline \multicolumn{2}{|l|}{ Entercom* } & May, 1998 & Nov. 2009 \\
\hline \multicolumn{2}{|l|}{ U.S. Stations } & 41 & 110 \\
\hline \multirow[t]{2}{*}{ U.S. Employees } & FT & 684 & 1,560 \\
\hline & PT & 250 & 750 \\
\hline \multicolumn{4}{|c|}{ Average Employees per station: } \\
\hline & $\begin{array}{l}\mathrm{FT} \\
\mathrm{PT}\end{array}$ & $\begin{array}{r}16.68 \\
61\end{array}$ & 14.8 \\
\hline \multicolumn{4}{|c|}{ *Note: Entercom did not own KWJJ in 1998.} \\
\hline
\end{tabular}

A number of factors could have influenced the appearance of a milder staff reduction at Entercom; most obviously, available data begins in May 1998, two years after the Act. This suggests Act-related staff cuts may have already taken place, although I am unable to show that here. However, Entercom's S-1 filing (1998) with the SEC discusses some possibilities along this line, stating:

Since October 1, 1996, the company...has acquired or agreed to acquire 36 radio stations, and has divested or agreed to divest, for strategic reasons, nine radio stations. ...As a result of these transactions, the company has divested its stand-alone stations, while establishing the largest clusters in Seattle and Kansas City, and building superduoplies in Boston, Portland [OR], Sacramento, and Rochester. ... The company believes that its proven record of consummating creative transactions...positions it well to continue to participate in the consolidation occurring in its industry."94

The report also states that Entercom "generated 97.6 percent of its pro forma fiscal 1997 net revenues from superduopolies...clusters of four or more stations in one market." To “enhance newly acquired underperforming stations," Entercom uses a variety of techniques, including "management enhancements, expenditure reductions, facility consolidation..." All this, familiar economies of scale, would suggest Portland lost 
significant numbers of Entercom jobs in the aftermath of the Telecom Act, and that average per-station Entercom jobs continued to decline after 1998. ${ }^{95}$

Before moving on to the comments of local broadcasters, note that I do not make a jobs comparison using the Alpha-owned stations, since both KINK and KUPL changed hands several times in the months following the Act, and were ultimately purchased (2009) by a newly formed broadcast entity (Alpha). Thus, my method of assessing perstation employee averages by drawing from company data over time would not apply.

Supporting the evidence of lost local radio news jobs is my Radio Survey 2011 (Appendix F), which indicates local professionals have noticed severe staff cuts. One radio veteran said:

The consolidation of radio resulted in drastic staff reductions and eliminated quality local [programming]. The station I have worked at for 23 years went from a thriving local business that provided above average wages and excellent benefits to its staff to a corporate cash cow in a matter of a few brief years. (Radio Survey 2011, Q. 17, response 10)

Another thought staff cutbacks had led to a frenetic work environment: "There are so few workers, everyone is rushing around just trying to fill the time with anything to keep the needles moving. ${ }^{, 96}$ To others, low staffing impaired their ability to produce in-depth stories: "[W]ith limited staffing, more quick and frequent newscasts, and growing responsibilities on our websites, it is increasingly difficult to really dig into topics." This underlines the link between broadcast news jobs and important political functions news media traditionally perform, a concern of the next section.

\section{Diminished Local News/Public Affairs in Portland}

In the absence of an unattainable content analysis (no adequate pre-Act air sample exists), my attempt to demonstrate diminished local news/public affairs relies on much 
the same data found in national assessments: lost jobs (see above section), a listener shift to public broadcasting, and shared content. In addition, I will offer findings from station public files documenting that news/public affairs declined in the Act's wake, and broadcasters' own accounts that their political role is truncated.

Just as the bump to NPR's audience was viewed as a thirst for more or higherquality political information (Kamenetz 2009), Portland-area radio listeners have shifted in droves to KOPB, the primary non-commercial radio station, since the Act (see Appendix L). While hovering around $10^{\text {th }}$ place in the late 1990 s ratings, KOPB improved its market position radically in 2001, where it has remained at or near the top in the ensuing years. This transition may have been due, at least in part, to dissatisfaction with news/public affairs offerings on local commercial stations (Sense of Place 2006).

It is indisputable that content has been increasingly shared over Portland's airwaves in the years following the 1996 Act, sometimes enabled by advances in technology (e.g. voice-tracking). However, such content is of concern here only to the degree that it displaces or distorts local news/public affairs. Content that merely "seems local" implies a loss in both the localism and diversity of news/public affairs. But, although listeners have posted complaints online about apparent voice-tracking ${ }^{97}$ the extent of voice-tracked content apparently has not been studied. Other forms of shared content are reported in station public files and by broadcasters themselves.

Since Act-induced consolidation, news/public affairs programming has declined on Portland radio; what remains is less local; and more of the locally produced content is shared (See Appendices J, K, and M). For example, in 1998, KWJJ 99.5 (then owned by Fisher Broadcasting) produced its own unique public affairs programming. As part of the 
Entercom cluster, KWJJ airs the same public affairs programs as KGON 92.3 and Entercom's other stations, sometimes at the same time (see Appendix M). In fact, locally produced Metroscope, is heard on all six of Entercom's Portland stations, ${ }^{98}$ as are the nationally syndicated Viewpoints and Radio Health Journal.

The practice of sharing public affairs programs within a cluster is far from unusual. Clear Channel, for example, shares its locally produced 30-minute Sunday Magazine among its cluster stations (four out of five of which run it at 7:00 AM Sundays). It also airs (and shares) Viewpoints, with the same content often being presented at precisely the same time. Sunday mornings at 7:30 AM, for example, at least three of Clear Channel's Portland stations, KXJM 107.5, KFBW 105.9, and KLTH 106.7, all broadcast Viewpoints. And since Entercom also runs Viewpoints on KGON 92.3 on Sunday mornings at 7:30, that brings to four the number of Portland stations airing Viewpoints, with the same subject matter, at the same time every week. ${ }^{99}$ In all, ten Portland stations run the same Viewpoints show at various times on the same day! Other such examples are shown in Appendix M.

While many public affairs programs have long been banished to the smallaudience wilderness of early Sunday mornings or late Sunday nights, at least on nonnews stations, their recent morphing into near lock-step content is a post-Telecom Act phenomenon. Because many of these stations in the Entercom and Clear Channel clusters had separate owners prior to the Act, they produced distinctive public affairs content that is homogenized today. Appendices $\mathrm{J}$ and $\mathrm{K}$ contrast news/public affairs content on KGON and KWJJ during the late 1990s with that of 2011. When station clusters air the 
same content in the same market, the number of perspectives - otherwise contained in broadcasts produced by diverse sources — necessarily shrinks.

The second shared-content concern is with pre-produced content. Public relations professionals have long provided media with "information subsidies" (Gandy 1982), in an effort to "intentionally shape the news agenda by reducing journalists' costs of gathering information" (Berkowitz and Adams 1990). While individual journalists may resist (Curtin 1999), the acceptance and use of information subsidies has increased with the rise of market imperatives in news production (Underwood 1993; McManus 1994).

Such supplements, ever more-sophisticated, enable media conglomerates to "synergistically" package a single idea across multiple platforms.

In the corporate dreams of media giants, synergy occurs when, for example, a magazine writes about an author, whose book is converted into a movie, (the CD soundtrack of which is played on radio stations), which becomes the basis for a television series which has its own Web site and computer games. (Croteau and Hoynes 2006, 78)

Promotional media products are appealing to broadcast journalists under pressure to produce more "news" for more stations, since they come specifically packaged for quick insertion into newscasts - complete with scripts and edited sound cuts. And, while useful information is no doubt contained in many such subsidies, democracy is diminished when news/public affairs is supplanted by what is essentially, subtly, a commercial. As Bagdikian puts it, in his disturbing account of five conglomerations dominating the media landscape, ${ }^{100}$ "media products are unique [in that] they manufacture a social and political world (Bagdikian 2004, 9). 
Radio Survey 2011 found large majorities of broadcast news professionals indicating they had shared more content, and used more content provided to them in recent years. ${ }^{101}$

Table 6.

As an on-air radio employee, are/were your news/public affairs stories shared more with another station(s) in recent years?

Table 7.

Yes: 11

No: 5

As a staff member (on or off the air) do/did you use more shared content (produced elsewhere in your company or parent company) in recent years?

Yes: 12

No: 3

Note that the nature of the shared content was unspecified, and could have referred to a variety of information subsidies, or to original material.

It is not only media giants that have decreased staff and homogenized content. In a sort of role reversal, Alpha Broadcasting, a newly formed local company (2009) purchased several Portland stations and pared news/public affairs offerings that had been spared even by CBS and other previous owners. At KUPL 98.7, for example, time devoted to local public affairs was cut in half, from an hour to 30 minutes. And, several public affairs features were dropped from KINK 101.9, including a national one-hour Newsweek Magazine summary of world and national events, as well as shorter pieces of about two minutes each: Kink Considers, a unique local analysis or commentary on a pressing public concern; Homepage, a family-issues segment; Discovering the Great Northwest, on natural resources; and Subject Earth, a brief environmental report. 
According to station public files, the only retained public affairs program on KINK, after its sale to Alpha, was Speaking Freely, a 30-minute local program. ${ }^{102}$

In what may have been the biggest democratic loss for local organizations after the Act, many Portland stations dropped small-event public service announcements (PSAs). Rather than publicizing scores of neighborhood happenings every week, stations trended toward fewer, larger events. The most conspicuous contrast between pre-Actstyle PSAs and events publicized after Act-spurred consolidation is shown in Appendix K. KWJJ's formerly eclectic daily announcements for myriad local groups were replaced by just two (larger- scale) events per quarter. This trend-away from small local-event publicity - toward fewer, larger promotions was common at Portland stations, according to public files and email inquiries to radio staff.

Although worthy organizations are among the few (but sizeable) radio-supported public service events, the exclusion of PSAs for spaghetti-feeds, photo exhibits, sports meets, and local Chamber of Commerce fundraisers is a toll on the ability of local groups to spread word of their projects. Supplanted by station-cluster mega-events, smaller projects found diminishing radio opportunities for publicity. Since democracy depends on political information, and radio channels are non-substitutable, this was apparently a trend away from democratic opportunities.

Although two Radio Survey 2011 participants thought the amount of local news/public affairs on Portland radio was the "right amount," 14 others thought "not enough" was provided.

Table 8.

As you see it, in terms of providing the public with an adequate source of local news/public affairs, Portland stations offer: 
Too much: $\quad 0$

Right amount: $\quad 2$

Not enough: $\quad 14$

Don't know: 0

And, 16 out of 17 participants thought "less time is now being allocated for local news/public affairs on local radio." As to reasons for the apparent decline, respondents were asked to choose a weighted response indicating, on a scale of $1-10$, the significance of several possible reasons:

Ownership efforts to reduce cost.

Buy-outs by larger media companies.

Audiences prefer non-news (entertainment).

People can get local news elsewhere (TV, Internet, etc.).

Other (please specify).

Not surprisingly, many participants thought, as shown in the graphs below, that ownership efforts to reduce costs and media company buy-outs were major reasons for diminished news/public affairs content (Figures 2 and 3).

Figure 2.

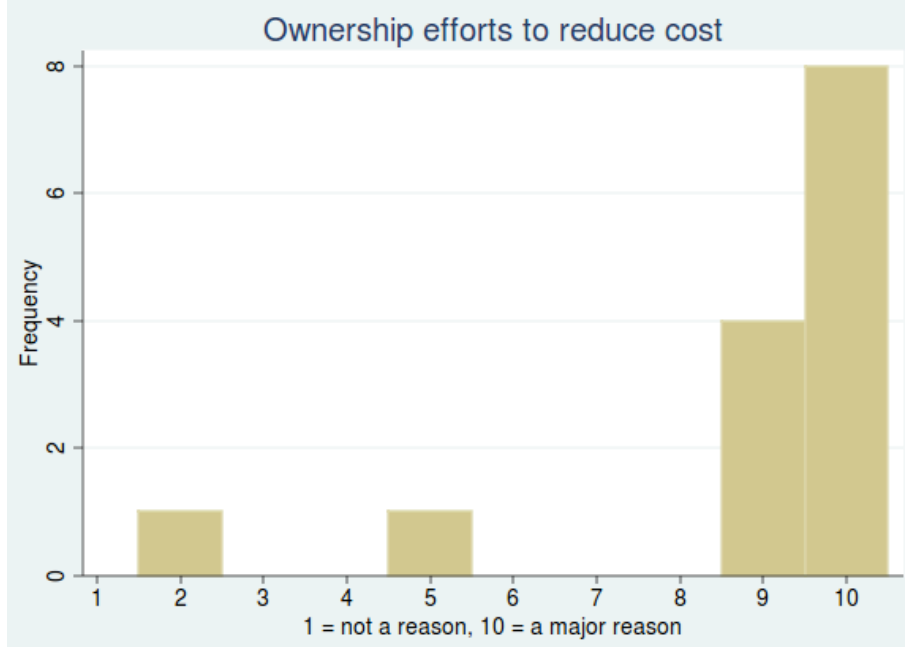


Figure 3.

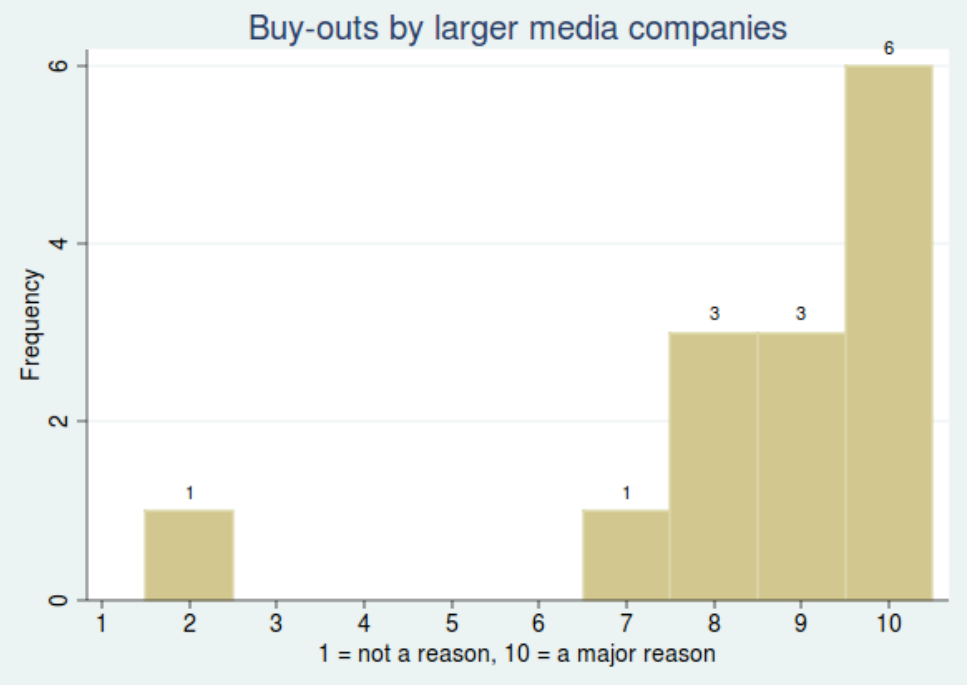

It is also noteworthy, though, that several broadcasters thought preferences for "non-news (entertainment)" and access to news "elsewhere (TV, Internet, etc.)" were factors in radio providing less news/pubic affairs.

Figure 4.

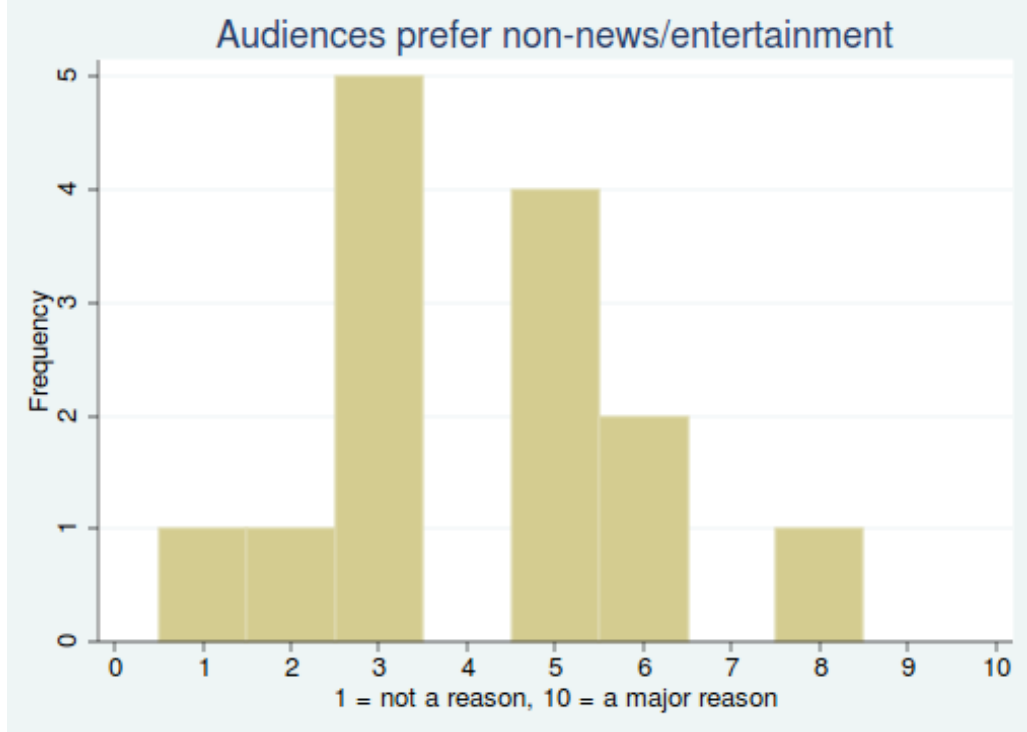


Figure 5.

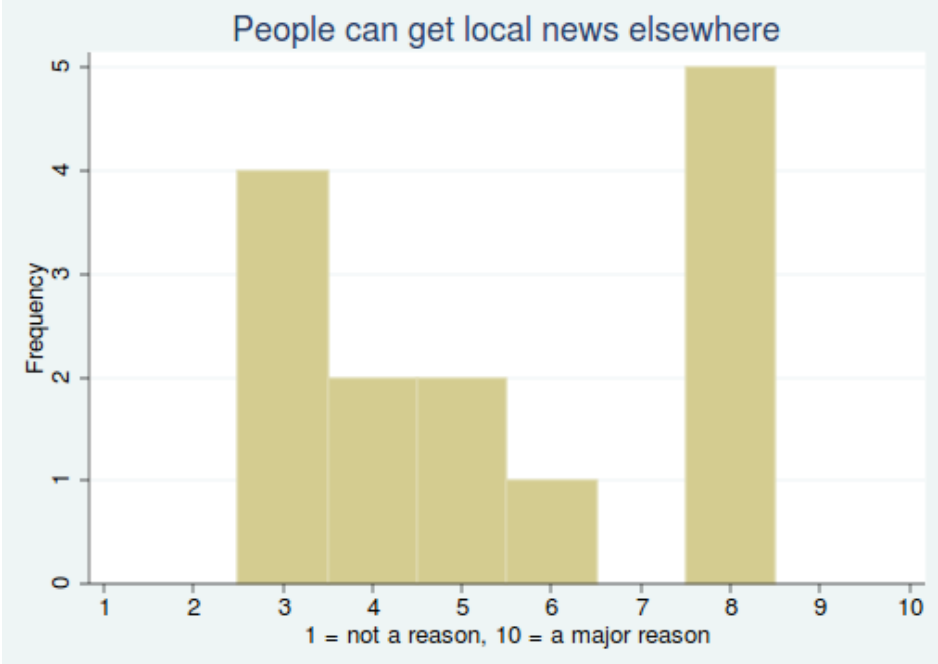

Worrisome, though, from the standpoint of a political role for radio news/public affairs was a strong consensus among local news broadcasters that the "current media environment" impinged on their ability to convey important news subjects to their audience - setting the agenda. Question 14 asked respondents to say whether they agreed or disagreed, and how strongly with the following statement: "As a broadcast journalist, I feel my ability to communicate important news subjects to my listening audience is limited in the current media environment."

Figure 6.

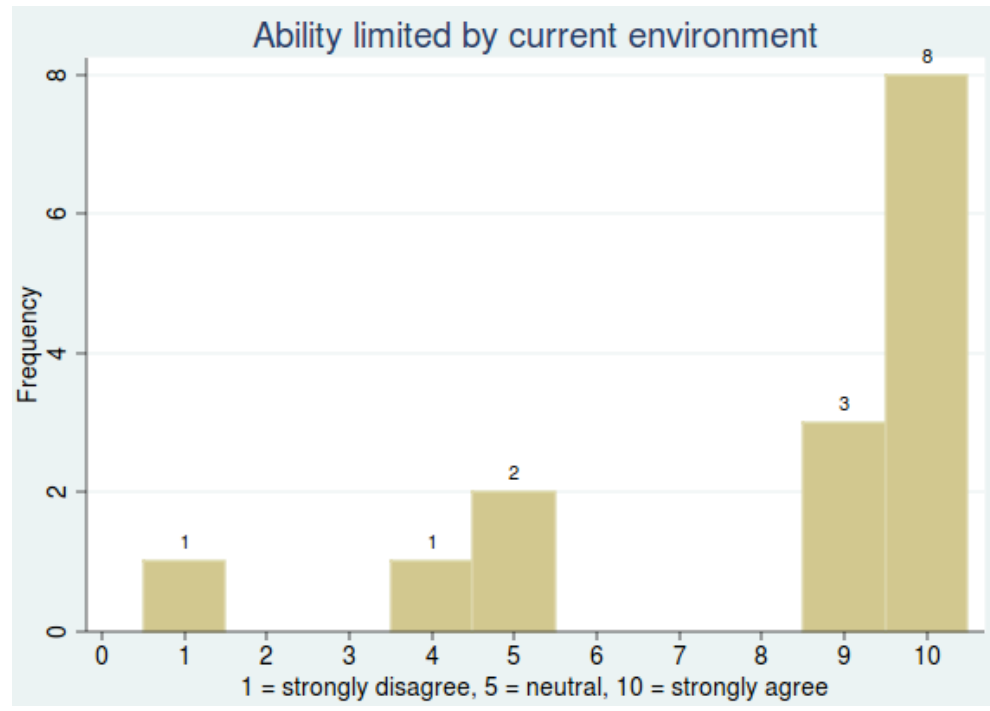


As figure 6 shows, 11 out of 15 broadcast journalists felt strongly that their agendasetting ability was hampered by current conditions in radio news. Said one, "Public service and news should help listeners participate in our cherished free and open society...bring them into the "process" of democracy, so to speak; and help them make informed decisions in all areas of political and community discourse" (Appendix F).

\section{Conclusions}

Since the post-Act rash of consolidation, economic constraints have increasingly shaped radio's political role, and the ability of broadcast journalists' to facilitate politics, highlight key issues, and provide a forum. The Act-prompted streamlining of station ownership ejected many thousands from jobs that specifically linked listeners to their communities and their representatives, sometimes replacing original news/public affairs with less-local content possibly formulated hundreds or even thousands of miles away. By 2005, "most local radio stations...offer[ed] virtually nothing in the way of reporters in the field" (Pew 2006). Gone were many institutional aspects of the broadcast journalist's job, "beat" coverage of local matters such as school board and city council meetings. Diminished, too, were many radio opportunities for communication about countless local events.

If Radio Survey 2011 is representative, most post-Act Portland radio journalists became more reliant on centralized, shared, or other low-budget content, than on (more costly) thoughtful, original, or investigative journalism. If lost jobs indicate fewer content decisions were made by local residents, news judgments following the Act were increasingly made elsewhere—diminishing the local in news/public affairs. The public discourse opportunities radio can offer are mocked by its conversion into a mere 
marketing vehicle for commodities, especially in Portland with its active utilization of political information.

True, technological advances (digital and portable options, Satellite radio) and economic pressures had already set in motion, prior to the Act, a decline in traditional radio news/public affairs (See part II, fig. 1, p. 27). That the Act exacerbated market model outcomes is apparent, though measuring them is an imprecise enterprise. My purpose here was to show that, whatever democratic opportunities radio may have offered before the Act, however narrowed by market imperatives they may have been, those opportunities were further weakened or eliminated because of the Act. If selfgovernance thrives on political information (as I argued in part II), and if radio is a nonsubstitutable channel (as I argued in part III), consequences of the Telecom Act become important to democracy.

Because nearly everyone listens to the radio, even if passively, and its messages can influence thought, broadcast content matters. It "just comes in," as one researcher described the saturation of media content — in homes and cars, in stores and malls, on phones and billboards, in films and popular music, at workplaces - even for those who make little effort to seek out media (McCombs and Shaw 1972, 177). In contrast, although information proliferates in the digital world, one may easily avoid unwanted Internet content. Thus the Internet-with its atomizing tendencies-is no substitute for democratic radio communication. At the very least, post-Act citizens may be less informed than they would be under a broadcast media policy aimed at engaged, informed citizens. Evidence presented here is consistent with the growing body of research indicating economic interests impinge on democratic discourse. 
This paper offers support for the return of abandoned community links articulated in, if imperfectly manifested by, the trustee model. The consequences of vanished institutional mechanisms (e.g. locally generated content, staffed news departments) documented in study after study are a loss to democracy, at a time when cynicism and polarized rhetoric characterize the public sphere. As Greider saw, "if the public sometimes seems dumb, it is because no institution takes responsibility for teaching them or for listening to them" (Greider 1993, 21). If Swanson (2000) is correct, shifting broadcast journalism away from commercial radio stations contributes to a class division of political information "haves" and "have nots."

An affirmative interpretation of the First Amendment, as Justice Stewart suggested, would enable institutional support for the mediating role of broadcast journalism. Such safeguarding becomes more critical with few private interests in control of most mass channels of speech and thought: newspapers, television, radio, cable, satellite, music, books, and film — and their corresponding digital presence on the Internet. As Justice Black put it:

It would be strange if the grave concern for freedom of the press which prompted adoption of the First Amendment should be read as a command that the government was without power to protect that freedom...essential to the welfare of the public...Freedom of the press from governmental interference...does not sanction repression of that freedom by private interests. ${ }^{103}$

Justice White declared, the public has a right "to receive suitable access to social, political, esthetic, moral, and other ideas", ${ }^{104}$ but such access is presently limited on commercial radio by market efficiencies. 
Perhaps most compelling is the need to place media policy on the public agenda. Indications are unmistakable that broadcast entities, through their powerful lobby apparatus, infinite station network, and apparent capture of officials and regulators, have been willing to withhold crucial details of media policy from the public (Barnouw 1966; Blevins and Brown 2010; Boehlert 2001; Dunbar 2006; McChesney 1993; Snider 2005; Stern 1996). This is a serious violation of the historic trust U.S. society has placed in broadcasters. Whether concerning main studio rules or ownership concentration, media policy should be subject to full democratic debate and decisions.

Of course, the public en masse was largely unaware of the 1996 Telecom Act; if its information source was mass media, how would it have known? When reported at all, mostly in print, the Act was covered "as a business story [about cable and phone rates] not a public policy story," though it would have an enormous impact on daily life (Wexler 2005, 7). This suggests a return to pre-1996 limits on media ownership, to allow for public debate on radio consolidation and its now-demonstrable effects. As Copps (2002) wondered, “ How can we possibly know if licensees are serving their communities without hearing from the community?" (Copps, 2004).

Tocqueville suggested, when ruling power is more "energetic and powerful... and when private individuals are more lethargic," useful social conventions are more necessary (Tocqueville [1840] 2003, 813). Because today market power reigns, I argue here for the return of such conventions, as embodied by local broadcast journalists. Though the public interest may be an almostmythical concept, restoring living, breathing humans to the radio newsroom is a 
real possibility — one that could restore a vibrant communication channel to the fabric of social life. 
${ }^{1}$ See Telecommunications Act of 1996, http://www.fcc.gov/telecom.html

${ }^{2}$ Unless otherwise specified, use of the term "radio" in this paper will always refer to commercial, advertiser-supported radio, as distinct from publicly subsidized, non-commercial radio.

${ }^{3}$ Although talk radio formats ("news/talk/information") enjoy significant listenership (Radio Today 2010) and are frequently focused on political topics (Pew 2011), they would be counted as political, for purposes of this paper, only to the extent that they fulfilled the political functions described (information facilitation between citizens and representatives; directing attention to important stories; offering a discussion platform).

${ }^{4}$ For the social-historical circumstances that contributed to the rise of media market forces (weakening U.S. economy, corporate transnationalism), see Sussman 1997, esp. 13-14, 100-113. For the decline of news/public affairs, see McChesney and Nichols 2010, 31; Keith 2007, 19; FCC Working Group $2011,60$. Many stations began scaling back their local news/public affairs programming after the FCC stopped requiring it in 1981. At the same time, new portable audio devices presented radio with new entertainmentonly competition, further discouraging informational programming. See Chen 1998.

${ }^{5}$ http://oxforddictionaries.com/definition/news?region=us

${ }^{6}$ For a detailed analysis of mainstream journalism's degradation, and restorative initiatives calibrated to traditional news values, especially for print media, see McChesney Nichols 2010.

${ }^{7}$ After publishing its nine-element list in 2006, Kovach and Rosenstiel added the $10^{\text {th }}$ element, citizen responsibilities, in their 2007 edition. See Kovach and Rosenstiel 2007.

${ }^{8}$ RTDNA (formerly RTNDA, the Radio Television News Directors Assn.) lists truth, fairness, integrity, accountability, and so on, at its website, http://www.rtdna.org/pages/media items/code-of-ethics-andprofessional-conduct48.php?id=48. For SPJ's similar ethics statement, see http://www.spj.org/ethicscode.asp. Both accessed August 29, 2011.

${ }^{9}$ Stewart and Colbert are but two examples of the political/satirical breed of journalism/activism flourishing in broadcast, in print, and online. For the subversive manipulation of spectacular images, "culture jamming," the "Yes Men," and The Onion, see Farrar and Warner, 2008.

${ }^{10}$ As Carter and Stelter (2010) note, Edward R. Murrow turned public opinion against the excesses of Sen. Joseph McCarthy in the 1950s. And, a Walter Cronkite editorial helped convince President Johnson he had lost public support for the Vietnam War in 1968. See Carter and Stelter 2010.

11 This online Time, Inc. Poll (2009) was not scientific, but merely reflective of Internet participants who chose to select from Stewart and mainstream evening news network anchors. See Time 2009.

12 Stewart and Colbert viewers tied with readers of major newspaper websites, followed closely by viewers of the NewsHour with Jim Lehrer, the O'Reilly Factor, and listeners of National Public Radio and Rush Limbaugh. See Pew Study 2007.

13 Brennan (1964) in New York Times v. Sullivan, 376 U.S. 254, 271. For all cases, see Cases Cited.

${ }^{14}$ Lasswell [1936] 1950. 
${ }^{15}$ Easton [1965] 1979.

16 For "the bottle bill", see Walth 1994. Vote-by-mail is detailed at

http://pewresearch.org/pubs/843/oregon-vote-by-mail and

http://prospect.org/cs/articles?article=the oregon voting revolution. For Oregon's record-breaking

initiative/referendum history, see http://www.iandrinstitute.org/Oregon.htm. For a summary of the Oregon

Health Plan, see https://facultystaff.richmond.edu/ bmayes/pdf/Oregon I.pdf All accessed Sept. 3, 2011.

17 For opposing perspectives on Oregon's land-use planning, see :

http://www.innobriefs.com/editor/20030423smartgrowth.html and

http://www.friends.org/landuseleadership. For sustainable or "green"-focused projects:

http://www.oregonsustainabilitycenter.org/about/. A worldwide bike-friendly-cities index is at

http://www.virgin-vacations.com/11-most-bike-friendly-cities.aspx. And, for details of Portland's electric

vehicle leadership, see http:/www.nytimes.com/2011/08/28/automobiles/portland-plans-for-transit-all-

powered-by-electricity.html?pagewanted=all All accessed Sept. 3, 2011.

${ }^{18}$ See Sanders 2008. His results are summarized herein, 26.

${ }^{19}$ For an overview of the spike in acquisitions, as documented by DiCola and Thomson (2002), see Appendix G.

${ }^{20}$ Clear Channel weathered years of derision from many quarters, including from Bagdikian (2004), McChesney (2004), later down-sizing to 894 stations.

${ }^{21}$ I explain the rationales behind both geographical and content-based localism in radio regulations in part III, Radio Regulation.

${ }^{22}$ FCC staff produced the study, "Do Local Owners Deliver," in 2004, but it did not come to light until the Senate confirmation hearing for FCC Chairman Kevin Martin. For the "suppressed studies," see Blevins and Brown 2010, 608, and Dunbar 2006. For the original study, eventually published by the FCC, see Alexander and Brown, 2004.

${ }^{23}$ Because Arbitron records were not stored electronically in 1996, hard copies are archived at a warehouse near the U. of Georgia Rare Book and Manuscript Library. An employee drove to the site and gathered the necessary data for me. http://www.libs.uga.edu/hargrett/index.shtml. The data base http://home.recnet.com/? documents radio ownership and license transactions.

${ }^{24}$ Annual reports did not specify the number of employees for any given station, so I calculated the average number of employees per station nationwide. If Portland is typical, this should be a valid estimate.

${ }^{25}$ To determine the precise nature of the lost jobs would require more rigorous research, especially since radio employees are often jacks-of-all trades, performing numerous station functions. However, considering national research (see part II, Literature, The Second Claim: Jobs Wiped Out), indicating substantial journalism jobs lost, combined with other research findings here (observations of industry professionals in the survey), and economies of scale associated with consolidation, it is reasonable to conclude that many, if not most, of the lost jobs were those of broadcast journalists.

${ }^{26}$ Radio stations are still required to maintain "inspection" files, available to the public. As outlined in "The Public and Broadcasting," produced by the FCC (2008), the FCC notes that, while it no longer routinely monitors the file's contents, stations are expected to "remain responsive to the needs of the local community." Thus, documents currently archived in station public files are less complex than in previous 
eras. "The Public and Broadcasting" is available at:

http://transition.fcc.gov/mb/audio/decdoc/public_and_broadcasting.html Accessed June 25, 2011.

${ }^{27}$ Two responses were excluded, since recipients indicated their jobs were not related to news/public affairs.

${ }^{28}$ For the entire survey, with responses entered in red, see Appendix F.

${ }^{29}$ http://www.oxforddictionaries.com/definition/democracy?view=uk Accessed May 16, 2011.

${ }^{30}$ Origin: 1375-1425; late Middle English < Late Latin mediātus, past participle of mediāre to be in the middle, intercede. http://dictionary.reference.com/browse/mediate Accessed May 15, 2011.

${ }^{31}$ Douglass Cater, The Fourth Branch of Government, in Cook 2005a, 1, 211 n2. Cook uses Cater's insight (that journalists play a governing role) as the foundation for his argument that the news media constitute a political institution. The fourth branch metaphor is traced to the nineteenth century, when Thomas Carlyle quoted Edmund Burke as saying, "there were Three Estates in Parliament; but in the Reporters' Gallery yonder there sat a Fourth Estate more important than they all," On Heroes, Hero Worship, (New York: Wiley and Putnam,1849) 147.

${ }^{32}$ See Bennett, Lawrence, and Livingston 2008; Cook 2005a; Patterson 1994.

${ }^{33}$ For a discussion of the distinction between speech and press, see Cook 2005b, especially Emily Erickson's "Afterword," 163-174. The Court has frequently conflated speech and press, a practice that may have added to doctrinal confusion. See Cook 2005a, 178. I avoid disentangling them here in order to focus on the distinction between public and private speech, whether issuing from the press or otherwise.

${ }^{34}$ New York Times v. U.S., 1971, 403 U.S. 713, 716. http://caselaw.lp.findlaw.com/cgibin/getcase.pl?navby=volpage\&court=us\&vol=403\&page=722 Accessed May 15, 2011.

${ }^{35}$ New York Times v. U.S., 1971, 403 U.S 713, 717.

${ }^{36}$ See Bill of Rights Transcript 1789.

http://www.archives.gov/exhibits/charters/bill_of_rights_transcript.html Accessed May 15, 2011.

${ }^{37}$ New York Times v. U.S., 1971, 403 U.S. 713, 720. 724.

${ }^{38}$ New York Times v. U.S., 1971, 403 U.S. 713, 728.

${ }^{39}$ While an institutional role could mean obligations to the public interest, it necessarily complicates the theoretical watchdog role. Cook points out that, in practice, the news media co-produce government "at least as much" as they check it. See Cook 2005a, entire, especially 117-192. See also Patterson 1994, 2852.

${ }^{40}$ New York Times v. U.S., 1971, 403 U.S. 713, 726.

${ }^{41}$ New York Times v. U.S., 1971, 403 U.S. 713, Burger at 745-48; Harlan at 753; Blackmun at 761.

${ }^{42}$ Associated Press v. U.S., 1945.

${ }^{43}$ Roth v. U.S., 1957.

${ }^{44}$ Hand, in the D.C. Circuit $A P$ decision, 1945. 
${ }^{45}$ New York Times v. Sullivan, 1964, 376 U.S. 254, 272, 375-6. Brennan's "breathing space" reference is from NAACP v. Button, 1963, 371 U.S. 415, 433.

${ }^{46}$ Whitney v. California, 1927, 274 U.S. 357, 375. See also Stern 1990, 927, and Sunstein 1995, 26-7.

${ }^{47}$ Red Lion Broadcasting v. FCC, 1969, 395 U.S. 367.

48 The public interest standard for radio, coined in the 1927 Radio Act, instructed the Federal Regulatory Commission (FRC) to uphold the "public interest, convenience, and necessity" in broadcast policy. For further discussion, see Krasnow 1997, Ford 1961, and part III herein, Radio Regulation. For "the public interest" as a broader policy-goal legacy of the Progressive Era, see McConnell 1966, entire, especially 47 50 .

${ }^{49}$ Munn v. Illinois 1877.

${ }^{50}$ According to the Pew Research Center's "State of the Media 2011" report, "unlike many other traditional media, that figure [93 percent listenership] has remained stable over time, slipping only 3 percentage points in the last decade." See Olmstead, Mitchell, and Rosenstiel, ๆ 9. See also Waldfogel, in Seabright and von Hagen 2007, 259-261.

${ }^{51}$ Marconi operators, including David Sarnoff, learned and spread news of the Titanic sinking, spurring new attention to wireless. Sarnoff went on to rise quickly through RCA, eventually helping found the National Broadcasting Company (NBC). Barnouw 1966, 43-52.

${ }^{52}$ Hoover's comments at this "Fourth Radio Conference" (1925) have been widely reported. A detail of interest to the present discussion, however, is usually omitted from popular accounts: The conference resolved, among other things, according to Ford (2008), "That the public interest as represented by service to the listener shall be the basis for the broadcasting privilege," 208, emphasis original. While avoiding the question of how listener satisfaction was to be measured, this offers at least a partial constitution of what was meant by "the public interest" several years before Great Lakes. The Court repeatedly affirmed the public's right over that of the broadcaster, generally in NBC v. US (1943), and specifically in Red Lion $v$ FCC (1969). See Cases Cited.

${ }^{53}$ NBC v. United States, 1943, 319 U.S 190.

${ }^{54}$ Associated Press v. U. S., 1945, 326 U.S 1.

${ }^{55}$ Abrams v. U.S., 1919, 250 U.S. 616.

${ }^{56}$ Turner Broadcasting Sys., Inc. v. FCC,1994, 512 U.S. 622.

${ }^{57}$ NBC v. U.S., 1943, 319 U.S. 190, at 202. See Prindle 2003, 290.

${ }^{58}$ FCC v. Allentown Broadcasting Corp., 1955, 349 U.S. 358, 362.

${ }^{59}$ Pinellas Broadcasting Co. v. FCC, 1956, 230 F.2d 204, 206 cert. denied, 350 US 1007.

${ }^{60}$ Broadcast Localism, Notice of Inquiry, 19 F.C.C.R. 12, 425, July 7, 2004.

${ }^{61}$ Local Community Radio Act of 2007, H.R. 2802, 110th Cong. (2007) 9.

${ }^{62}$ Primer on Ascertainment of Community Problems by Broadcast Applicants, 27 FCC 2d 650 (1971), 
which was largely consistent with the agency's 1960 Policy statement, 25 Fed. Reg. 7291, 7295 (1960), in Krasnow and Goodman 1998, 615-6.

${ }^{63}$ Public Law 632, in Kahn 1984, 40; in Barnouw 1966, 300.

${ }^{64}$ NBC v. U.S., 1943, 319 U.S. 190.

${ }^{65}$ For details of the Public Service Responsibility of Broadcast Licensees, the Blue Book's formal title, see Kahn 1984, 149-163.

${ }^{66} 8$ FCC 333, 1941, in Kahn 1984, 122.

${ }^{67} 13$ FCC 1246, in Kahn 1984, 173.

${ }^{68}$ Red Lion Broadcasting Co. v. FCC, 1969, 395 U.S. 367

${ }^{69} 25$ Fed. Reg. 7291, 7295 (1960), in Krasnow and Goodman 1998, 615-6.

${ }^{70}$ Henry v. FCC, 1962, 302 F. 2d 191, 7.

${ }^{71}$ City of Camden, 1969, 18 FCC F. 2d 412. Notwithstanding interviews indicating residents wished for more local news, the license applicant in Camden had intended to drastically reduce news/public affairs programs. See Collins 1980, 582.

72 Deregulation of Radio, Report and Order, 84 F.C.C.2d 968, 49 Rad. Reg. 2d (P \& F) 1 (1981), aff'd in part and remanded in part sub. nom. Office of Comm. of the United Church of Christ v. FCC, 1983, 707 F.2d 1413. See Krasnow and Goodman 1998, 616.

${ }^{73}$ Elimination of Unnecessary Brdcst. Reg. and Inquiry into Subscription Agreements, 54 Rad. Reg. 2d (P \& F) 1043 (1983), in Krasnow and Goodman 1998, 641 n40.

${ }^{74} 800$ F.2d 1181 (D.C. Cir. 1986), cert. denied, 482 U.S. 919 (1987), ibid, n41.

75 Revision of Applications for Renewal of License of Commercial and Non-commercial AM, FM, and Television Licensees, 49 R.R.2d (1981) 740, 744-45, in Hagelin and Wimmer, 217.

${ }^{76}$ FCC, 1985a; Syracuse Peace Council v. Federal Communications Commission 1989, in Napoli 2003, 14.

${ }^{77}$ As Baker notes, Congress pressured the FCC to modify slightly by adding a provision to stop station acquisition if, within a single broadcast category (TV, AM, FM), an owner was reaching more than 25 percent of the nationwide audience. See Baker 2002a, 867-8.

${ }^{78}$ Although the spectrum-allocation part of the 1996 Telecom Act was delayed, and remained controversial, eventually being implemented in stages, it was contained in the Act passed in 1996. See Snider 2005, entire. For the observation that any broadcast Act coverage was largely presented in the context of business stories regarding cable and phone rates, excluding mention of the spectrum allocation, see Wexler 2005, 7. For Sen. Bob Dole's accusation that the NAB was misleading viewers and "bullying" Congress, see Stern $1996,6$.

${ }^{79}$ See n18. FCC staff produced the study, "Do Local Owners Deliver," in 2004, but it did not come to light until the Senate confirmation hearing for FCC Chairman Kevin Martin. For the "suppressed studies," see Blevins and Brown 2010, 608, and Dunbar 2006. For the original study, eventually published by the FCC, see Alexander and Brown, 2004. 
${ }^{80}$ Although Sen. Bob Dole in a speech entitled "Broadcast Blackout" declared, "You will not see this story on any television or hear it on any radio broadcast because it directly affects [broadcasters]," and, while Snider and others have demonstrated the dearth of TV coverage, I could find no research into such content on radio. (It may be impossible to study in the absence of institutional record-keeping typical of radio.) Dole is quoted in Snider 2005, 442.

${ }^{81}$ Summarized from Kimmelman, Scott, and Cooper 2006, 61-2; Cooper 2006, 345-7, the cooperative Consumers Union, Consumer Federation of America, and Free Press Response to FCC 06-93 Notice of Proposed Rule Making.

${ }^{82}$ Report, Editorializing by Broadcast Licensees, 13 F.C.C. 1246 (1949), in Rainey 1993, 269.

${ }^{83}$ For anti-federalist arguments against the U.S Constitution (and hence a large-scale republic), since it would be too remote from local "laws, customs, and opinions," see Ketcham (2003), especially 231, 264; Bimber (2003); and Rose (1989), 79. For Tocqueville's worry that democracy detached citizens from their fellows, see Tocqueville ([1840] 2003), 589. Dewey ([1927] 1988) emphasizes the importance of local associations at 113, as does Delli Carpini (2000) at 17.

${ }^{84}$ Note that station estimates vary somewhat, since the FCC uses a "signal-contour" market definition, which can allow ownership of more stations-per-market than would otherwise be permitted using Arbitron estimates. (For example, DiCola (2006) finds that 104 markets had more stations than local limits allowed, even with relaxed rules as of 1996.) This sometimes leads to disparate estimates of how many stations exist in a "market." For a discussion of the signal-contour issue, see DiCola 2006, 51-53. Herein, I use a combined estimate from three databases: http://licensing.fcc.gov/prod/cdbs/pubacc/prod/sta sear.htm, http://home.recnet.com/? and http://www.pdxradio.com/FM AM Owners.html I omitted stations whose existence I was unable to document.

${ }^{85}$ Two AM stations (KPAM 860 AM and KKJY/KDZR 1640 AM), along with one FM (KAST/KRYP 93.1 FM) were added to the Portland market since 1996. Although the number of estimated stations may vary for technical reasons (signal contours, see DiCola 2006, 51-53 n79), I documented the existence of 43 stations. See http://licensing.fcc.gov/prod/cdbs/pubacc/prod/sta_sear.htm, http://cdbs.recnet.net:8080/fmq.php?call=kryp, and http://www.pdxradio.com/FM_AM_Owners.html. All accessed June 21, 2011.

${ }^{86}$ As Appendix C shows, Arbitron has begun rating online streams and HD2 "stations" separately from their source station, giving the appearance of additional stations in the Portland market. Because these contain essentially the same content and staff as their associated traditional station, I do not count these as additional stations.

${ }^{87}$ Note that this excludes the public station, KOPB, lately always at or near the top of the ratings. As shown in Appendix L, the high market ranking for KOPB is a leap from a much lower position in the late 1990sa development related, I argue, to the loss of news/public affairs on commercial radio.

${ }^{88}$ According to Blevins, Sen. Barbara Boxer produced two such studies during re-nomination hearings for FCC Chair Kevin Martin. Martin indicated he was unaware of the studies, and pointed out that he was not chair when the research took place. See Blevins 2010, 613 for his account of the "suppressed" studies.

${ }^{89}$ Note that Entercom did not own KWJJ until 2003, so any jobs comparison suggested here would not have applied. Entercom did own KGON, the other station in the pair, in 1998.

90 Clear Channel data, obtained from U.S. SEC: fiscal year 1996:

http://www.sec.gov/Archives/edgar/data/739708/0000739708-97-000006.txt; 
fiscal year 2009: http://www.sec.gov/Archives/edgar/data/739708/000119312510058288/d10k.htm; and Clear Channel Outdoor data, 2009,

http://www.sec.gov/Archives/edgar/data/1334978/000119312510058241/d10k.htm. See Appendix I.

${ }^{91}$ Entercom data, (per S-1) filed 8/13/98, U.S. SEC:

http://www.sec.gov/Archives/edgar/data/1067837/0000893220-98-001351.txt;

92 Entercom data, (per S-1) filed fiscal year 2009, U.S. SEC:

http://www.sec.gov/Archives/edgar/data/1067837/000110465910014263/a09-35761_110k.htm

${ }^{93}$ SEC documents for Fisher Broadcasting, which owned KWJJ in 1997, were not helpful, since they combined radio and TV staffs, making a comparison invalid.

${ }^{94}$ See S-1 filing, n86, at 6.

${ }^{95}$ See S-1 filing, n86, at 5, 7.

${ }^{96}$ Although this comment is from a survey respondent, it was made in a related email and does not appear in the Survey Text Responses.

${ }^{97}$ See http://archive.pdxradio.com/messages/208652/213471.html Accessed May 26, 2011.

${ }^{98}$ See Entercom's Metroscope web page: http://www.metroscopepdx.com/

${ }^{99}$ Content was cross-checked in public files for each program at every station.

${ }^{100}$ Although Bagdikian's list of the dominant media conglomerates is largely still current at this writing, Comcast's acquisition of NBC Universal (2011), adds Comcast to the list. It also takes media mergers to a new level by placing control of content and distribution in the same hands, arguably threatening to cableize the Internet and weaken independent content production. See Copps 2011, and Dunbar 2011.

${ }^{101}$ See questions 15 and 16, Radio Survey 2011 Responses, Appendix F.

${ }^{102}$ Source: KUPL and KINK public files.

${ }^{103}$ Associated Press v. US, 1945, 20.

${ }^{104}$ Red Lion Broadcasting v. FCC 1969, 390. 


\section{Works Cited}

"AIR Director: NPR Serves 'Liberal, Highly Educated Elite,' Wonders How to Justify Public Funding | NewsBusters.org." NewsBusters.org | Exposing Liberal Media Bias. March 11, 2011. Accessed July 07, 2011.

http://www.newsbusters.org/blogs/lachlan-markay/2011/03/11/npr-boardmember-admits-it-serves-liberal-highly-educated-elite-wond.

Alexander, Peter Jeffrey., and Keith Brown. Do Local Owners Deliver More Localism? Some Evidence From Local Broadcast News. Report. July ed. 2004. Accessed April 21, 2011. http://transition.fcc.gov/ownership/materials/alreadyreleased/doownersdeliver032904.pdf.

"Americans' View Of The Press | Why America Hates The Press | FRONTLINE | PBS." PBS: Frontline. 1995. Accessed June 19, 2011. http://www.pbs.org/wgbh/pages/frontline/shows/press/other/view.html.

Bagdikian, Ben H. The New Media Monopoly. Boston: Beacon Press, 2004.

Baker, C. Edwin. Advertising and a Democratic Press. Princeton, NJ: Princeton University Press, 1994.

Baker, C. Edwin. Media Concentration and Democracy: Why Ownership Matters. Cambridge: Cambridge University Press, 2007.

Baker, C. Edwin. "Media Concentration: Giving up on Democracy." Florida Law Review 54 (December 2002a): 839-95.

Baker, C. Edwin. Media, Markets, and Democracy. Cambridge: Cambridge University Press, 2002b.

Baker, Charles Edwin. "The Media That Citizens Need." In LexisNexis, 317. Vol. 147. U. Pa. Law Review, 1998.

http://www.lexisnexis.com.proxy.lib.pdx.edu/hottopics/lnacademic/.

Barnouw, Erik. A Tower in Babel: A History of Broadcasting in the United States - to 1933. Vol. 1. New York: Oxford University Press, 1966.

Barron, Jerome A. "Access to the Press--A New First Amendment Right." Harvard Law Review 80, no. 8 (June 1967): 1641-678.

Baumgartner, Jody, and Jonathan Morris. "The Daily Show Effect: Candidate Evaluations, Efficacy, and American Youth." American Politics Research 34, no. 3 (2006): 341-67. doi:10.1177/1532673X05280074. 
Baym, Geoffrey. From Cronkite to Colbert: the Evolution of Broadcast News. Boulder: Paradigm Publishers, 2010.

Bednarski, Anastasia. "Diversity to Duplication: Mega-Mergers and the Failure of the Marketplace Model Under the Telecommunications Act of 1996." Federal Communications Law Journal 55 (March 2003): 274-95.

Bennett, W. Lance, Regina G. Lawrence, and Steven Livingston. When the Press Fails: Political Power and the News Media from Iraq to Katrina. Chicago: University of Chicago Press, 2008.

Berkowitz, Dan, and Douglas Adams. "Information Subsidy and Agenda-Building in Local Television News." Journalism Quarterly 67 (Winter 1990): 723-31.

"Bill of Rights Transcript." National Archives and Records Administration. Accessed May 15, 2011.

http://www.archives.gov/exhibits/charters/bill_of_rights_transcript.html.

Bimber, Bruce. Information and American Democracy: Technology in the Evolution of Political Power. Cambridge: Cambridge University Press, 2003.

Blevins, Jeffrey Lane, and Duncan H. Brown. "Concerns About the Disproportionate Use of Economic Research in the FCC's Media Ownership Studies From 2002-2007." Journal of Broadcasting and Electronic Media 54, no. 4 (2010): 603-20.

Blosser, Larry A., Ben Scott, Jeannine Kenney, Gene Kimmelman, and Glenn B. Manishin. "The Case Against Big Media." StopBigMedia.com. 2007. Accessed June 26, 2011. http://www.stopbigmedia.com/=compendium.

Boehlert, Eric. "One Big Happy Channel?" Salon.com. June 28, 2001. Accessed May 12, 2011. http://www.salon.com/technology/feature/2001/06/28/telecom_dereg.

Boggs, Carl. The End of Politics: Corporate Power and the Decline of the Public Sphere. New York: Guilford Press, 2000.

Brecht, Bertolt, and John Willett. Brecht on Theatre: the Development of an Aesthetic. New York: Hill and Wang, [1918-1956] 1974.

Brown, James A. "Struggle Against Commercialism: The 1934 "Harney Lobby" for Nonprofit Frequency Allocations." Journal of Broadcasting \& Electronic Media, Summer, 33, no. 3 (1989): 273-91.

Cao, Xiaoxia. "Hearing It From Jon Stewart: The Impact of The Daily Show on Public Attentiveness to Politics." International Journal of Public Opinion Research 22, 
no. 1 (February 2010).

Carr, Craig L. Liberalism and Pluralism: the Politics of E Pluribus Unum. New York: Palgrave Macmillan, 2010.

Carter, Bill, and Brian Stelter. "In 'Daily Show' Role on 9/11 Bill, Echoes of Murrow." New York Times, December 26, 2010, Global ed., Business Day Media and Advertising sec. Accessed August 31, 2011. http://www.nytimes.com/2010/12/27/business/media/27stewart.html?src=me.

Chen, Sing-Ling S. "Electronic Narcissism: College Students' Experiences of Walkman Listening." Qualitative Sociology 21, no. 3 (1998): 255-77.

Cole, Harry, and Patrick Murck. "The Myth of the Localism Mandate: A Historical Survey of How the FCC's Actions Belie the Existence of a Governmental Obligation to Provide Local Programming." In CommLaw Conspectus, 339-78. Vol. 15. Catholic University of America, 2007. Accessed May 9, 2011. http://www.lexisnexis.com.proxy.lib.pdx.edu/hottopics/lnacademic/.

Collins, Tom A. "The Local Service Concept in Broadcasting: An Evaluation and Recommendation for Change." Iowa Law Review 65 (1980): 507-91. Accessed May 28, 2011. http://scholarship.law.wm.edu/facpubs/507.

"Communications Act of 1934." Fcc.gov. Accessed May 7, 2011. http://www.fcc.gov/Reports/1934new.pdf.

Compaine, Benjamin. "The Media Monopoly Myth: How New Competition Has Expanded American's Sources of Information and Entertainment." New Millennium Research, May 4, 2005. Accessed June 12, 2011. http://newmillenniumresearch.org/archive/\#reports.

Cook, Timothy E. Freeing the Presses: the First Amendment in Action. Baton Rouge: Louisiana State University Press, $2005 b$.

Cook, Timothy E. Governing with the News: The News Media as a Political Institution. Chicago: University of Chicago Press, 2005a.

Cooper, Mark. The Contemporary Terrain of Media Policy. Report no. Part VII:

Compendium: Response to FCC 06-93 Notice of Proposed Rule Making. 2006. Accessed April 15, 2011. http://www.stopbigmedia.com/=compendium.

Copps, Michael J. Speech, REMARKS OF COMMISSIONER MICHAEL J. COPPS FCC HEARING ON LOCALISM AND LICENSE RENEWAL, SAN ANTONIO, TEXAS, 2004. Accessed April 25, 2011. http://tap.gallaudet.edu/Policy/FCC/CoppsComments.asp. 
Copps, Michael J. DISSENTING STATEMENT OF COMMISSIONER MICHAEL J. COPPS. Report. Federal Communications Commission, 2011. http://hraunfoss.fcc.gov/edocs_public/attachmatch/DOC-304134A3.pdf.

Coronel, Sheila S. The Media as Watchdog. Report no. Harvard-World Bank Workshop. Harvard Kennedy School, 2008. http://www.hks.harvard.edu/fs/pnorris/Conference/Conference\%20papers/Corone 1\%20Watchdog.pdf.

Corwin, Edward Samuel, and J. W. Peltason. Corwin \& Peltason's Understanding the Constitution. Fort Worth: Harcourt Brace College Publishers, 1997.

Croteau, David, and William Hoynes. The Business of Media: Corporate Media and the Public Interest. Thousand Oaks, CA: Pine Forge Press, 2007.

Curtin, Patricia A. "Reevaluating Public Relations Information Subsidies: Market-driven Journalism and Agenda-building Theory and Practice." Journal of Public Relations Research 11, no. 1 (1999): 53-90.

Dahl, Robert A. Democracy and Its Critics. New Haven: Yale University Press, 1989.

Dearing, James W., and Everett M. Rogers. Agenda-Setting. Thousand Oaks: Sage, 1996.

Delli Carpini, Michael X. "In Search of the Informed Citizen: What Americans Know about Politics and Why It Matters." The Communication Review 4, no. 1 (2000): 129-64.

Dewey, John. The Public and Its Problems. Chicago: Swallow Press, [1927] 1988.

DiCola, Peter, and Kristin Thomson. "Radio Deregulation: Has It Served Citizens and Musicians?" Future of Music Coalition. November 18, 2002. Accessed April 28, 2011. http://futureofmusic.org/sites/default/files/FMCradiostudy.pdf.

DiCola, Peter. "Choosing between the Necessity and Public Interest Standards in FCC Review of Media Ownership Rules Interest Standards." Michigan Law Review 106, no. 1 (October 2007): 101-33.

DiCola, Peter. "Employment and Wage Effects of Radio Consolidation." Future of Music Coalition. August 9, 2006a.

http://futureofmusic.org/sites/default/files/EmloymentEffectsRadioConsolidation0 6.pdf.

DiCola, Peter. "False Premises False Promises: A Quantitative History of Ownership Consolidation in the Radio Industry." Futureofmusic.org. 2006b. Accessed May 8, 
2011. http://futureofmusic.org/sites/default/files/FMCradiostudy06.pdf.

Dotinga, Randy. "'Good Mornin' (Your Town Here)'" Wired.com, August 6, 2002. Accessed June 9, 2011. http://www.wired.com/techbiz/media/news/2002/08/54037

Dunbar, John. Lawyer: FCC Ordered Media Study Destroyed. Publication. September 14, 2006. http://www.tvnewscheck.com/article/2006/09/14/6535/lawyer-fcc-orderedmedia-study-destroyed.

Dunbar, John. "A Television Deal for the Digital Age." Columbia Journalism Review 49, no. 5 (January 2011): 34-38. http://www.cjr.org/feature/a_television_deal_for_the_digi.php.

Easton, David. A Systems Analysis of Political Life. Chicago: University of Chicago Press, 1979.

Epstein, Lee, and Thomas G. Walker. Constitutional Law for a Changing America. Washington, D.C.: CQ Press, 2010.

Fallows, James. "Why Americans Hate the Media." The Atlantic, February 1996. http://www.theatlantic.com/magazine/archive/1996/02/why-americans-hate-themedia/5060/.

FCC Working Group. Information Needs of Communities. Report. June. 2011. http://www.fcc.gov/info-needs-communities\#read.

Fog, Agner. The Supposed and the Real Role of Mass Media in Modern Democracy. Working paper. 2004. Http://www.agner.org/cultsel/mediacrisis.pdf.

Folami, Akilah N. "Deliberative Democracy on the Air: Reinvigorating Localism-Resuscitating Radio's Subversive Past." Federal Communications Law Journal 63 (December 2010): 141-92.

Ford, Frederick W. "The Meaning of the Public Interest, Convenience, or Necessity." Journal of Broadcasting 5, no. 3 (Summer 1961): 205-18.

Fowler, Mark S., and Daniel L. Brenner. "A Marketplace Approach to Broadcast Regulation." Texas Law Review 60 (1981): 207-56.

Fowler, Mark S. "The Public's Interest." Florida Bar Journal 56 (March 1982): 213-17.

Gandy, Oscar H. Beyond Agenda Setting: Information Subsidies and Public Policy. Norwood, NJ: Ablex Pub., 1982. 
Goodman, Mark, and Mark Gring. "The Radio Act of 1927: Progressive Ideology, Epistemology and Praxis." Rhetoric and Public Affairs 3, no. 3 (2000): 397-418. doi:10.1353/rap.2010.0055.

Graber, Doris A. Media Power in Politics. Washington, D.C.: CQ Press, 2007.

Greider, William. Who Will Tell the People: the Betrayal of American Democracy. New York: Simon \& Schuster, 1993.

Gurevitch, Michael, and Jay G. Blumler. "Political Communications Systems and Democratic Values." In Democracy and the Mass Media: a Collection of Essays., 269-89. Cambridge: Cambridge University Press, 1993.

Habermas, Jürgen. The Structural Transformation of the Public Sphere: an Inquiry into a Category of Bourgeois Society. Cambridge, MA: MIT Press, [1962] 1989.

Habermas, Jürgen. Between Facts and Norms: Contributions to a Discourse Theory of Law and Democracy. Cambridge, MA: Polity Press, 2004.

Hagelin, Theodore M., and Kurt A. Wimmer. "Broadcast Deregulation and the Administrative Responsibility to Monitor Policy Change: An Empirical Study of the Elimination of Logging Requirements." Federal Communications Law Journal 38 (August 1986): 201-322.

Hartley, John. "Radiocracy: Sound and Citizenship." International Journal of Cultural Studies 3, no. 2 (2000): 153-59.

Herman, Edward S., and Noam Chomsky. Manufacturing Consent: the Political Economy of the Mass Media. New York: Pantheon Books, 2002.

Higgins, Carey Lynne. Does the "News" Come First? Social Responsibility, Infotainment, and Local Television Newscasts in Portland, Oregon: A Content Analysis. Thesis, Portland State University - MS, Communication Studies, 2005.

Howard, Jill. "Congress Errs in Deregulating Broadcast Ownership Caps: More Monopolies, Less Localism, Decreased Diversity and Violations of Equal Protection." CommLaw Conspectus 5 (Summer 1997): 269-305.

Huber, Peter W. Law and Disorder in Cyberspace: Abolish the FCC and Let Common Law Rule the Telecosm. Oxford: Oxford University Press, 1997.

"Implementing the National Broadband Plan | Benton Foundation." Benton Foundation | The Benton Foundation Works to Ensure That Media and Telecommunications Serve the Public Interest and Enhance Our Democracy. March 2010. Accessed April 27, 2011. http://benton.org/initiatives/national_broadband_plan. 
Ingber, Stanley. "The Marketplace of Ideas: A Legitimizing Myth." Duke Law Journal 1 (February 1984): 1-91.

"Inventor of the Week: Trevor Baylis." Massachusetts Institute of Technology: LemelsonMIT, December 2007. Accessed September 13, 2011. http://web.mit.edu/invent/iow/baylis.html.

Iyengar, S., M. D. Peters, and D. R. Kinder. "Experimental Demonstrations of the "NotSo-Minimal" Consequences of Television News Programs." American Political Science Review, 1982, 76, no. 4, 848-58.

Izard, Ralph S., Hugh M. Culbertson, and Donald A. Lambert. Fundamentals of News Reporting. Dubuque, IA: Kendall/Hunt Pub., 1973.

Johnson, Steven Reed. "The Myth and Reality of Portland's Engaged Citizenry and Process-Oriented Government." In The Portland Edge: Challenges and Successes in Growing Communities, 102-17. Washington, DC: Island Press, 2004.

Kahn, Frank J. Documents of American Broadcasting. Englewood Cliffs, NJ: PrenticeHall, 1984.

Kamenetz, Anya. "Will NPR Save the News? | Fast Company." FastCompany.com Where Ideas and People Meet | Fast Company. April 1, 2009. Accessed July 07, 2011. http://www.fastcompany.com/magazine/134/finely-tuned.html.

Kellner, Douglas. Television and the Crisis of Democracy. Boulder, CO: Westview Press, 1990.

Keith, Michael C., The Radio Station: Broadcast, Satellite, and Internet. Burlington, MA: Focal Press, 2007.

Ketcham, Ralph, ed. The Anti-Federalist Papers ; And, the Constitutional Convention Debates. New York, NY: Signet Classic, [1787-88] 2003.

"Key Findings | State of the Media." The State of the News Media 2011. Accessed May 11, 2011. http://stateofthemedia.org/2011/overview-2/key-findings/.

Kimmelman, Gene, Ben Scott, and Mark Cooper. Compendium: Response to FCC 06-93 Notice of Proposed Rule Making. Issue brief no. Part II: The Continuing Importance of Localism. 2006. Accessed April 15, 2011. http://www.stopbigmedia.com/filing/summary.pdf.

Kovach, Bill, and Tom Rosenstiel. The Elements of Journalism: What Newspeople Should Know and the Public Should Expect. New York: Three Rivers Press, 2007. 
Kovach, Bill, Tom Rosenstiel, and Amy Mitchell. Striking the Balance, Audience Interests, Business Pressures and Journalists' Values. Report. Project for Excellence in Journalism. Pew Research Center, 1999. Accessed June 17, 2011. http://www.journalism.org/node/419.

Krasnow, Erwin, and Jack N. Goodman. "The "Public Interest" Standard: The Elusive Search for the Holy Grail." Federal Communications Law Journal 50 (1998): 605-35.

Kull, S., C. Ramsey, and E. Lewis. "Misperceptions, the Media, and the Iraq War." Political Science Quarterly 118, no. 4 (2003): 569-98.

Lanson, Jerry, and Mitchell Stephens. Writing and Reporting the News. New York: Oxford University Press, 2008.

Lasswell, Harold Dwight. Politics, Who Gets What When and How. New York: Peter Cmith, [1936] 1950.

LeGuin, Ursula K. "The Writing Life." Writers-Editors Network. Accessed October 20, 2011. http://www.writersandeditors.com/the_writing_life_58899.htm.

Leigh, Robert D., ed. A Free and Responsible Press; a General Report on Mass Communication: Newspapers, Radio, Motion Pictures, Magazines, and Books. ("The Hutchins Commission Report" Chicago: University of Chicago Press, [1947] 1974.

Lubar, Steven D. InfoCulture: the Smithsonian Book of Information Age Inventions. Boston: Houghton Mifflin, 1993.

Madison, James. Electronic Resources from the University of Chicago Press Books Division. August 4, 1822. Accessed June 23, 2011. http://presspubs.uchicago.edu/founders/documents/v1ch18s35.html.

Madison, James. The Complete Madison: His Basic Writings. Edited by Saul Kussiel Padover. New York: Harper, 1953.

Mangarian, Gregory P. "Substantive Media Regulation in Three Dimensions." George Washington Law Review 76, no. 4 (June 2008): 845-96.

Marris, Paul, and Sue Thornham. Media Studies: a Reader. New York: New York Univ. Press, 2008.

Mathews, Anna Wilde. "A Giant Radio Chain Is Perfecting the Art of Seeming Local." Wall Street Journal, February 25, 2002. Accessed May 26, 2011. 
http://www.lexisnexis.com.proxy.lib.pdx.edu/hottopics/lnacademic/.

May, Randolph J. "The Public Interest Standard: Is It Too Indeterminate to Be Constitutional?" Federal Communications Law Journal 53 (2001): 427.

McChesney, Robert W., and John Nichols. The Death and Life of American Journalism: the Media Revolution That Will Begin the World Again. Philadelphia, PA: Nation Books, 2010.

McChesney, Robert W. Telecommunications, Mass Media, and Democracy: the Battle for Control of U.S. Broadcasting, 1928-35. New York, N.Y. ; Oxford: Oxford University Press, 1993.

McChesney, Robert Waterman. "Waging the Media Battle." The American Prospect, July 2004. http://prospect.org/cs/articles?article=waging_the_media_battle.

McCombs, Maxwell E., and Donald L. Shaw. "The Agenda-setting Function of the Mass Media." Public Opinion Quarterly 36, no. 2 (Summer 1972): 176-87.

McConnell, Grant. Private Power and American Democracy. New York: Alfred A. Knopf, 1966.

McManus, John H. Market-driven Journalism: Let the Citizen Beware? Thousand Oaks, CA: Sage Publications, 1994.

McQuail, Denis. McQuail's Mass Communication Theory. 4th ed. London: Sage., 2000.

Media Bureau. "THE PUBLIC AND BROADCASTING: How to Get the Most Service From Your Local Station." FCC, 2008. Accessed April 28, 2011. http://transition.fcc.gov/mb/audio/decdoc/public_and_broadcasting.html.

Meiklejohn, Alexander. Political Freedom; the Constitutional Powers of the People. New York: Harper, [1948] 1960.

Mill, John Stuart, and John Gray. On Liberty and Other Essays. Oxford: Oxford University Press, [1859] 1998.

Mills, C. Wright. The Power Elite. New York: Oxford University Press, [1956] 1999.

Molotch, Harvey, and Marilyn Lester. "News as Purposive Behavior." American Sociological Review 39, no. 1 (February 1974).

Moss, D. A., and M. R. Fein. "Radio Regulation Revisited: Coase, the FCC, and the Public Interest." Journal of Policy History, 4th ser., 14 (2003): 388-417. 
Napoli, Philip M. Foundations of Communication Policy: Principles and Process in the Regulation of Electronic Media. Cresskill, NJ: Hampton Press, 2003.

Napoli, Philip. "The Localism Principle in Communications Policymaking and Policy Analysis: Ambiguity, Inconsistency, and Empirical Neglect." Policy Studies Journal 29, no. 3 (2001): 372-87.

Napoli, Philip M. Media Diversity and Localism: Meaning and Metrics. Mahwah, N.J: Lawrence Erlbaum Associates, 2007.

Nossiter, Bernard D. "The F.C.C.'s Big Giveaway Show." The Nation, October 26, 1985.

Olmstead, Kenny, Amy Mitchell, and Tom Rosenstiel. "State of the Media 2011." Pew Research Center's Project for Excellence in Journalism. Accessed April 30, 2011. http://stateofthemedia.org/2011/audio-essay/.

Patterson, Thomas E. Out of Order. New York: Vintage Books, 1994.

Pauly, John. "Journalism and the Crisis of Democracy: The U.S. Perspective." Communication Research Trends 19 (1999): 3-48. Accessed June 18, 2011. http://cscc.scu.edu/trends/v19/v19_4.pdf.

Pew Center: Changing Definitions of News. Report. March ed. 1998. Accessed August 30, 2011. http://www.journalism.org/node/442.

Pew Center: State of the Media 2004: What Is the State of Content in Radio News? Report. 2004. Accessed April 25, 2011. http://stateofthemedia.org/2004/radiointro/content-analysis/.

Pew Center: State of the Media 2006: An Annual Report on American Journalism. Report. http://stateofthemedia.org/2006/overview/. Accessed June 28, 2011.

Pew Center: State of the Media 2010. Report. Accessed April 27, 2011. http://pewresearch.org/pubs/1523/state-of-the-news-media-2010.

Pew Center: State of the Media 2011. Report. Accessed April 27, 2011. http://stateofthemedia.org/2011/audio-essay/.

Pew Center: Journalism, Satire or Just Laughs? "The Daily Show with Jon Stewart" Examined. Report. Pew Research Center, 2008. Accessed August 31, 2011. http://www.journalism.org/node/10953\#fn1.

Pew Center: Public Knowledge of Current Affairs Little Changed by News and Information Revolutions. Report. Pew Research Center, 2007. Accessed August 31, 2011. http://people-press.org/2007/04/15/public-knowledge-of-current-affairs- 
little-changed-by-news-and-information-revolutions/.

Pickard, Victor. "Reopening the Postwar Settlement for U.S. Media: The Origins and Implications of the Social Contract Between Media, the State, and the Polity." Communication, Culture, and Critique 3 (2010): 170-89. Accessed August 24, 2011. doi:10.1111/j.1753-9137.2010.01065.x.

Powers, William. "Radio Rich." National Journal, 2003 ser., 35, no. 46 (November 15, 2003): 1-4.

Prindle, Gregory M. "No Competition: How Radio Consolidation Has Diminished Diversity and Sacrificed Localism." Fordham Intellectual Property, Media \& Entertainment Law Journal, Fall 2003, 279-316.

"Public Knowledge and Benton Foundation Want Universal Service To Be Universal | Benton Foundation." Benton Foundation | The Benton Foundation Works to Ensure That Media and Telecommunications Serve the Public Interest and Enhance Our Democracy. April 19, 2011. Accessed May 21, 2011. http://benton.org/node/56411.

Putnam, Robert D., Lewis M. Feldstein, and Don Cohen. Better Together: Restoring the American Community. New York: Simon \& Schuster, 2003.

"Radio Today." 2010. Accessed April 30, 2011. http://www.arbitron.com/.

Radio's Leading Indicator. Report. 2005. Accessed May 30, 2011. http://www.arbitron.com/study/leading.asp.

Rainey, R. Randall, and William Rehg. "The Marketplace of Ideas, the Public Interest, and Federal Regulation of the Electronic Media: Implications of Habermas' Theory of Democracy." Southern California Law Review 69 (September 1996): 1923-87.

Rainey, R. Randall. "The Public's Interest in Public Affairs Discourse, Democratic Governance, and Fairness in Broadcasting: A Critical Review of the Public Interest Duties of the Electronic Media." Georgetown Law Journal 82 (December 1993): 269-365.

Rasmussen, Scott. "Nearly One-Third of Younger Americans See Colbert, Stewart As Alternatives to Traditional News Outlets." Rasmussen Reports, March 25, 2009. Accessed August 31, 2011. http://www.rasmussenreports.com/public_content/lifestyle/entertainment/march_2 009/nearly one third of younger_americans see colbert stewart as alternative s_to_traditional_news_outlets. 
Rathbun, Elizabeth. "Radio Station Trading Hot." Broadcasting and Cable, April 22, 1996.

"Report on Broadcast Localism and Notice of Proposed Rulemaking." FCC.gov. January 2008. Accessed May 6, 2011. http://hraunfoss.fcc.gov/edocs_public/attachmatch/FCC-07-218A1.pdf.

Rose, Carol M. "The Ancient Constitution vs. the Federalist Empire: Antifederalism from the Attack on "Monarchism" to Modern Localism." Yale Law School Legal Scholarship Repository, Faculty Scholarship Series, Paper 1823 (1989): 74-107. Accessed May 27, 2011. http://digitalcommons.law.yale.edu/fss_papers/1823.

Rosen, Philip T. The Modern Stentors: Radio Broadcasters and the Federal Government, 1920-1934. Westport, CT: Greenwood Press, 1980.

Sanders, Tyrone. American Local Radio Journalism: a Public Interest Channel in Crisis. Diss., University of Oregon, 2008. Eugene, 2008. Accessed April 25, 2011. https://scholarsbank.uoregon.edu/xmlui/bitstream/handle/1794/7507/Tyrone_Sand ers_doctoral_thesis_winter2008.pdf? sequence $=2$.

Schattschneider, Elmer Eric. The Semisovereign People: a Realist's View of Democracy in America. Boston: Wadsworth, [1960] 2008.

Schudson, Michael. The Good Citizen: a History of American Civic Life. Cambridge, MA: Harvard University Press, 2002.

Schwartzman, Andrew Jay, Cheryl A. Leanza, and Harold Feld. "Reforming the Fourth Estate: The Future of Media Literature Review." Global Media Project, May 7 , 2008. Accessed May 12, 2011. http://www.watsonblogs.org/globalmedia/2008/05/reforming_the_fourth_estate_t h.html.

Seabright, Paul, and Jürgen Von Hagen, eds. The Economic Regulation of Broadcasting Markets : Evolving Technology and the Challenges for Policy. Cambridge: Oxford University Press, 2007.

Sense of Place: Values of Localism Research. Report. Public Radio Program Directors Association, 2006. Accessed September 19, 2011. http://www.prpd.org/knowledgebase/exploring_a_sense_of_place.aspx.

Siebert, Fred S., Wilbur Schramm, and Theodore Peterson. Four Theories of the Press: the Authoritarian, Libertarian, Social Responsibility, and Soviet Communist Concepts of What the Press Should Be and Do. Urbana: University of Illinois Press, 1956. 
Silberman, Jeff. "Virtual Radio Becomes Real Option." In Billboard Magazine. Feb. 6, 1999. Los Angeles.

Smith, F. Leslie, Milan D. Meeske, and John W. Wright. Electronic Media and Government: the Regulation of Wireless and Wired Mass Communication in the United States. White Plains, NY: Longman Publishers, 1995.

Smythe, Dallas W. "Radio: Deregulation and the Relation of the Private and Public Sectors." Journal of Communication 32, no. 1 (Winter 1982): 192-200.

Snider, J. H. Speak Softly and Carry a Big Stick: How Local TV Broadcasters Exert Political Power. New York: IUniverse, 2005.

Staples, Brent. "The Trouble with Corporate Radio." NY Times Advertisement, February 20, 2003. Accessed April 28, 2011. http://www.nytimes.com/2003/02/20/opinion/editorial-observer-trouble-withcorporate-radio-day-protest-music-died.html? scp=1.

Stephens, Mitchell. A History of News: from the Drum to the Satellite. New York, N.Y., U.S.A.: Viking, 1988.

Stern, Christopher. "Dole: Broadcasters "Bullying Congress""' Broadcasting and Cable, April 22, 1996.

Stern, Paul G. "A Pluralistic Reading of the First Amendment." Yale Law Journal 99, no. 4 (January 1990): 925-44.

Stone, Melville. "Associated Press Statement of News Values and Principles." Accessed August 24, 2011. http://www.ap.org/newsvalues/index.html.

Sunstein, Cass. Echo Chambers: Bush v. Gore, Impeachment and Beyond. Princeton, NJ: Princeton University Press, 2001. Electronic. doi:ISBN 1-4008-0905-3.

Sunstein, Cass R. Democracy and the Problem of Free Speech. New York: Free Press, 1995.

Sunstein, Cass R. Free Markets and Social Justice. New York: Oxford University Press, 1997.

Sunstein, Cass R. Republic.com. Princeton: Princeton University Press, 2002.

Sussman, Gerald. Communication, Technology, and Politics in the Information Age. Thousand Oaks: Sage, 1997.

Sussman, Gerald, and J. R. Estes. "Community Radio in Community Development." In 
The Portland Edge: Challenges and Successes in Growing Communities, 118. Portland, OR: PSU, 2004.

Swanson, David L. "The Homologous Evolution of Political Communication and Civic Engagement: Good News, Bad News, and No News." Political Communication 17, no. 4 (2000): 409-14. doi:10.1080/10584600050179031.

"Telecommunications Act of 1996. Pub. LA. No. 104-104, 110 Stat. 56." Federal Communications Commission (FCC) Home Page. 1996. Accessed May 11, 2011. http://www.fcc.gov/telecom.html.

"Time Polls: Poll Results - Now That Walter Cronkite Has Passed On, Who Is America's Most Trusted Newscaster?| TIME." Time Polls. July 22, 2009. Accessed August 31, 2011.http://www.timepolls.com/hppolls/archive/poll_results_417.html.

Tocqueville, Alexis De. Democracy in America and Two Essays on America. Translated by Gerald E. Bevan. London, England: Penguin Books, [1835-40] 2003.

Underwood, Doug. When MBAs Rule the Newsroom: How the Marketers and Managers Are Reshaping Today's Media. New York: Columbia University Press, 1993.

Walth, Brent. "No Deposit, No Return: Richard Chambers, Tom McCall, and the Oregon Bottle Bill." Oregon Historical Quarterly 95, no. 3 (Fall 1994): 278-99.

Wexler, Celia Viggo. The Fallout From the Telecommunications Act of 1996:

Unintended Consequences and Lessons Learned. Report. Edited by Mary Boyle. Washington, D.C.: Common Cause Education Fund, 2005. Accessed May 28, 2011. http://www.commoncause.org/atf/cf/\%7BFB3C17E2-CDD1-4DF6-92BEBD4429893665\%7D/FALLOUT_FROM_THE_TELECOMM_ACT_5-9-05.PDF. 


\section{Cases Cited}

1. Abrams v. U.S., 250 U.S. 616 (1919)

2. Associated Press v. U. S., 326 U.S. 1 (1945)

3. Burlington Northern R. Co. v. Bell, 482 U.S. 919 (1987)

4. City of Camden 18 FCC F.2d 412 (1969) (See Collins 1980, 582).

5. FCC v. Allentown Broadcasting Corp., 349 U.S. 358 (1955)

6. Henry v. FCC, 302 F.2d 191 (1962)

7. NAACP v. Button, 371 U.S. 415 (1963)

8. NBC v. US, 319 U.S. 190 (1943)

9. New York Times v. Sullivan, 376 U.S. 254 (1964)

10. New York Times v. U.S., 403 U.S. 713 (1971)

11. Pinellas Broadcasting Co. v. FCC, 230 F.2d 204, 206 cert. denied. 350 US 1007 (D.C. Cir. 1956)

12. Red Lion Broadcasting v. FCC, 395 U.S. 367 (1969)

13. Syracuse Peace Council v. Federal Communications Commission 1989

14. Turner Broadcasting Sys., Inc. v. FCC, 512 U.S. 622 (1994)

15. United Church of Christ v. FCC, 707 F.2d 1413 (1983)

16. Whitney v. California, 274 U.S. 357 (1927) 


\section{Appendix A}

\section{FCC 1960 Programming Policy Statement}

"The major elements usually necessary to meet the public interest, needs and desires of the community in which the station is located as developed by the industry, and recognized by the Commission, have included:

1. Opportunity for Local Self-Expression

2. Development and Use of Local Talent

3. Programs for Children

4. Religious Programs

5. Educational Programs

6. Public Affairs Programs

7. Editorialization by Licensees

8. Political Broadcasts

9. Agricultural Programs

10. News Programs

11. Weather and Market Reports

12. Sports Programs

\section{Service to Minority Groups}

14. Entertainment Programming

The elements set out above are neither all-embracing nor constant. ...The ascertainment of the needed elements of the broadcast matter to be provided by a particular licensee for the audience he is obligated to serve remains primarily the function of the licensee."

Excerpts from FCC 1960 Programming Policy Statement, 25 Fed. Reg. 7291, 7295 (1960). Source: Krasnow and Goodman 1998, 615-6, and Kahn 1984, 200-1. 
Appendix B

PORTLAND STATIONS OWNERSHIP HISTORY $\quad$ 1996-2011
$1996=40$ stations
$2011=43$ stations
$1996=30$ owners
$2011=21$ owners

\section{AM Stations}

1. 620 KPOJ Embarcadero Media, Inc.

[EXCL Communications, Inc. / 2-20-97]

[Jacor Communications, Inc. / 2-25-97]

[Clear Channel Communications, Inc. / 5-4-99] (KPOJ)

current 2011

2. $750 \mathrm{KXL}$ Alexander Broadcasting Co., Inc. (KXTG)

[Rose City Radio Corp. / 11-30-98]

[Alpha Broadcasting / announced 5-12-09]

current 2011

3. 800 KPDQ Salem Communications Corp. $\quad$ (KPDQ)

4. 860 KPAM Pamplin Communications Corp. (KPAM)

current 2011 (signed on Oct., 1997)

5. 910 KKSN Heritage Media Corp.

[Fox - News Corporation / 3-17-97]

[Sinclair Broadcast Group, Inc. / 7-16-97]

[Entercom Radio, LLC / 3-1-98]

(KTRO)

current 2011

6. 940 KWBY

[94 Country Inc.] current 2011

7. 970 KBBT Henry Broadcasting Co.

[American Radio Systems License Corp. / 5-20-96]

[Infinity Broadcasting Corp. / 6-4-98]

[CBS Radio Stations, Inc. / 12-14-05]

[Alpha Broadcasting] current 2011

8. 1010 KXYQ Spartan Media, Inc.

[KGUY, LLC / 3-28-00]

[Northwest Radio Broadcasting Co. / 12-4-01]

[Bustos Media, LLC / 10-29-03]

[Adelante Media] current 2011

(KUFO) 


\section{9. $1040 \mathrm{KXPD}$}

[Churchill Media] current 2011

10. 1080 KWJJ Park Communications, Inc.

[Fisher Broadcasting, Inc. / 5-8-96]

[Entercom Communications Corp. / 12-18-03] (KFXX )

current 2011

11. 1150 KKEY Western Broadcasting Co.

[Western Broadcasting Co. / 3-1-98]

[Western Broadcasting Co. / 7-29-99]

[Bustos Media, LLC / 8-21-03]

$(\mathrm{KXET})$

[Adelante Media/2011]

current 2011

12. 1190 KEX Citicasters, Inc.

[Jacor Communications, Inc. / 12-31-96]

[Clear Channel Communications, Inc. / 5-4-99]

(KEX)

13. 1230 (KMUZ) KRYN

[Bustos Media 5-3-03]

[Salem Folklore Community 2008]

[Adelante Media] current 2011

14. 1330 KKPZ Crawford Broadcasting Co.

[KPHP Radio] current 2011

(KKPZ)

15. 1360 KUIK Dolphin Communications, Inc.

[Westside Radio, Inc. / 7-1-08]

(KUIK)

16. 1410 AM $2^{\text {nd }}$ Amendment Foundation

[KBNP Radio] current 2011

17. 1450 KBPS Portland Public Schools

18. 1480 KBMS Vancouver, WA

[Christopher Bennett Broadcasting]

current 2011

19. $1520 \mathrm{KFXX}$ [Fisher to Entercom 2003] [Adelante Media of OR]

current 2011

(KGDD)

20. 1550 KVAN Vancouveradio, Inc.

[Pamplin Communications Corp. / 11-20-98] (KKAD)

[Pamplin/Alexandra/comopadres/Centro Cristiano]

[Vernon Snyder] current 2011

21. 1640 KKJY Crawford Broadcasting Co. 
[Radio Disney Group, LLC / 2-16-03] (KDZR)

current 2011

** signed on, May, 1998

\section{FM Stations}

22. 88.3 Non-commercial, Catholic

(KBVM)

[Catholic Broadcasting NW] current 2011

23. 89.1 KMHD Non-commercial, Ed.

[Mt. Hood Community College] current 2011

24. 89.9 KQAC Non-commercial, Ed.

[All Classical Public Media, Inc.]

current 2011

25. 90.7 KBOO Non-commercial, Ed.

[The KBOO Foundation]

current 2011

26. 91.5 KOPB Non-commercial, Ed.

[Oregon Public Broadcasting]

current 2011

27. 92.3 KGON Entercom Radio, LLC

current 2011

$(\mathrm{KGON})$

28. 93.1 KAST-FM Youngs Bay Broadcasting (Note: Astoria station until 2006)

[New Northwest Broadcasters, Inc. / 10-26-99]

(signed on from Gladstone Feb 1, 06)

[Salem Communications Corp. / 11-9-04] (KRYP)

[Ohana Media Group 2009]

[Salem Media] current 2011

29. 93.9 KPDQ-FM Salem Communications Corp. (KPDQ-FM)

30. 94.7 KNRK Entercom Radio, LLC

current 2011

(KNRK)

31. 95.5 KXL-FM Alexander Broadcasting Co., Inc.

[Rose City Radio Corp. / 11-30-98]

[Alpha Broadcasting] (KXTG)

current 2011

32. 97.1 KKSN-FM Heritage Media Corp.

[Fox - News Corporation / 3-17-97]

[Sinclair Broadcast Group, Inc. / 7-16-97]

[Entercom Radio, LLC / 3-1-98]

$(\mathrm{KYCH})$ 
current 2011

\section{98.7 KUPL-FM Baycom}

[American Radio Systems License Corp. / 8-1-96]

[Infinity Broadcasting Corp. / 6-4-98]

[CBS Radio Stations, Inc. / 12-14-05]

[Alpha Broadcasting/2009] current 2011

(KUPL)

34. 99.5 KWJJ-FM Park Communications, Inc.

[Fisher Broadcasting, Inc. / 5-8-96]

[Entercom Communications Corp. / 12-18-03] (KWJJ)

current 2011

35. 100.3 KKRZ Citicasters, Inc.

[Jacor Communications

[Clear Channel Communications, Inc. / 5-4-99] (KKRZ)

current 2011

36. 101.1 KUFO Henry Broadcasting Co.

[American Radio Systems License Corp. / 5-20-96]

[Infinity Broadcasting Corp. / 6-4-98]

[CBS Radio Stations, Inc. / 12-14-05]

[Alpha/2009] current 2011

37. 101.9 KINK Embarcadero Media, Inc.

[EXCL Communications, Inc. / 2-20-97]

[American Radio Systems License Corp. / 5-15-98]

[Infinity Broadcasting Corp./ 5-27-98]

[CBS Radio Stations, Inc. / 12-14-05] ］ (KINK)

[Alpha/2009] current 2011

38. 103.3 KKCW Citicasters, Inc.

[Jacor Communications, Inc. / 12-31-96]

[Clear Channel Communications, Inc. / 5-4-99] (KKCW)

current 2011

39. 104.1 KFIS Oregon Eagle, Inc.

[Thunderegg Wireless, LLC / 2-4-99]

[Salem Communications Corp. / 9-20-01] (KWPK)

[Caron Broadcasting 2001]

[Horizon Broadcasting Group] current 2011

40. 105.1 KRSK Heritage Media Corp.

[Fox - News Corporation / 3-17-97]

[Sinclair Broadcast Group, Inc. / 7-16-97]

[Entercom Radio, LLC / 3-1-98]

(KRSK)

41. 105.9 KFBW Citicasters, 1996

[acquired by Jacor] 
[acquired by Clear Channel '99]

current 2011

(KQOL)

42. 106.7 KLTH Baycom

[American Radio Systems License Corp. / 8-1-96]

[Infinity Broad [Infinity Broadcasting Corp. / 6-4-98]

[CBS Radio Stations, Inc. / 12-14-05]

[Clear Channel Communications, Inc./ 4-1-09] (KLTH)

current 2011

43. 107.5 KDBX Salem Communication Corp.

[American Radio Systems License Corp. / 7-25-96]

[Infinity Broadcasting Corp. / 6-4-98]

[CBS Radio Stations, Inc. / 12-14-05]

[Clear Channel Communications, Inc./ 4-1-09] (KXJM)

**Note: Two AM stations, KPAM (860 AM) and KKJY/KDZR (1640 AM), along with one FM KAST/KRYP (93.1 FM) were added to the Portland market since 1996.

As previously noted, station estimates vary for technical reasons ("signal contours"). This is a combined estimate of station histories I could document.

Sources: http://licensing.fcc.gov/prod/cdbs/pubacc/prod/sta sear.htm, http://home.recnet.com/? and http://www.pdxradio.com/FM AM Owners.html 


\section{Appendix C Portland Stations Arbitron Ratings 2011}

\begin{tabular}{|c|c|c|c|c|c|}
\hline \multicolumn{2}{|c|}{$\begin{array}{l}\text { Station } \\
\text { Ranking } \\
\text { Outlet }\end{array}$} & nat & $\begin{array}{l}\text { Mar. } \\
\text { MAR } 11\end{array}$ & $\begin{array}{l}\text { Apr. } \\
\text { APR } 11\end{array}$ & $\begin{array}{l}\text { May } \\
\text { MAY } 1\end{array}$ \\
\hline 1 & KLTH-FM & Classic Hits & 5.6 & 6.4 & 8.1 \\
\hline 2 & KKCW-FM & Adult Contemporary & 8.6 & 7.9 & 7.7 \\
\hline 3 & KUPL-FM & Country & 5.1 & 5.5 & 6.1 \\
\hline $4 \mathrm{t}$ & KGON-FM & Classic Rock & 4.9 & 5.2 & 5.8 \\
\hline $4 \mathrm{t}$ & KKRZ-FM & Hot Adult Contemporary & 6.0 & 6.0 & 5.8 \\
\hline 6 & KXJM-FM & Pop Contemporary Hit Radio & 4.8 & 5.3 & 5.7 \\
\hline 7 & KOPB-FM & News Talk Information & 6.6 & 5.7 & 4.7 \\
\hline 8 & KINK-FM & Album Adult Alternative & 4.0 & 4.0 & 4.5 \\
\hline 9 & KWJJ-FM & Country & 3.8 & 4.3 & 4.4 \\
\hline $10 \mathrm{t}$ & KFIS-FM & Contemporary Christian & 3.1 & 4.2 & 4.2 \\
\hline $10 \mathrm{t}$ & $\mathrm{KYCH}-\mathrm{FM}$ & Adult Hits & 3.2 & 4.0 & 4.2 \\
\hline $12 \mathrm{t}$ & KFBW-FM & Classic Rock & 5.0 & 4.7 & 4.0 \\
\hline $12 \mathrm{t}$ & KRSK-FM & Hot Adult Contemporary & 2.6 & 3.1 & 4.0 \\
\hline 14 & KEX-AM & News Talk Information & 3.1 & 3.2 & 3.5 \\
\hline 15 & KXL-AM & News Talk Information & 2.6 & 3.0 & 3.3 \\
\hline 16 & KNRK-FM & Album Adult Alternative & 3.0 & 3.1 & 2.9 \\
\hline 17 & KRYP-FM & Mexican Regional & 2.6 & 2.9 & 2.6 \\
\hline $18 \mathrm{t}$ & KQAC-FM & Classical & 2.3 & 2.3 & 1.9 \\
\hline $18 \mathrm{t}$ & KXTG-FM & All Sports & 2.2 & 2.2 & 1.9 \\
\hline 20 & KFXX-AM & All Sports & 2.4 & 2.3 & 1.8 \\
\hline 21 & KMHD-FM & Jazz & 1.9 & 1.3 & 1.2 \\
\hline 22 & KPAM-AM & News Talk Information & 1.2 & 0.9 & 1.1 \\
\hline 23 & KUFO-AM & Talk/Personality & 0.9 & 1.1 & 1.0 \\
\hline 24 & KPOJ-AM & Talk/Personality & 1.1 & 1.0 & 0.9 \\
\hline $25 \mathrm{t}$ & KLVP-FM & Contemporary Christian & 0.5 & 0.7 & 0.8 \\
\hline $25 \mathrm{t}$ & KPDQ-FM & Religious & 1.2 & 1.0 & 0.8 \\
\hline $25 \mathrm{t}$ & KZZR-FM & Mexican Regional & 0.4 & 0.7 & 0.8 \\
\hline $28 \mathrm{t}$ & KPWX-AM & Mexican Regional & 0.7 & 0.5 & 0.6 \\
\hline $28 \mathrm{t}$ & KSND-FM & Spanish Adult Hits & 0.7 & 0.7 & 0.6 \\
\hline $30 \mathrm{t}$ & KFIS-FM Stream & Contemporary Christian & * & 0.4 & 0.5 \\
\hline $30 \mathrm{t}$ & KWIP-AM & Mexican Regional & 0.3 & 0.3 & 0.5 \\
\hline $32 \mathrm{t}$ & KFBW-FM HD2 & Classic Hits & * & 0.1 & 0.3 \\
\hline $32 \mathrm{t}$ & KHPE-FM & Contemporary Christian & 0.4 & 0.5 & 0.3 \\
\hline $32 t$ & KINK-FM Stream & Album Adult Alternative & * & * & 0.3 \\
\hline $32 \mathrm{t}$ & KWBY-AM & Mexican Regional & 0.3 & 0.2 & 0.3 \\
\hline $32 \mathrm{t}$ & KXET-AM & Spanish Contemporary & 0.5 & 0.3 & 0.3 \\
\hline $32 \mathrm{t}$ & KYKN-AM & News Talk Information & 0.2 & 0.3 & 0.3 \\
\hline $32 \mathrm{t}$ & KZRI-FM & Contemporary Christian & 0.3 & 0.2 & 0.3 \\
\hline $39 t$ & KBOO-FM & Variety & 0.4 & 0.3 & 0.2 \\
\hline $39 t$ & KGDD-AM & Mexican Regional & 0.3 & 0.2 & 0.2 \\
\hline $39 t$ & KLVU-FM & Contemporary Christian & 0.2 & 0.1 & 0.2 \\
\hline $39 t$ & KMHD-FM HD2 & Alternative & * & * & 0.2 \\
\hline $39 t$ & KPDQ-AM & Religious & 0.2 & 0.2 & 0.2 \\
\hline 44 & KKSN-AM & Alternative & * & 0.1 & 0.1 \\
\hline
\end{tabular}

Data unavailable:

\begin{tabular}{|c|c|c|c|c|}
\hline * & KBNP-AM & News Talk Information & 0.1 & * \\
\hline * & KKOV-AM & Adult Standards/MOR & 2.3 & 1.4 \\
\hline * & KRYN-AM & Spanish News/Talk & 0.2 & * \\
\hline * & KXL-FM & News Talk Information & 2.4 & * \\
\hline
\end{tabular}

Source: http://www.arbitron.com/radio stations/home.htm accessed July 7, 2011 
Appendix D

Portland, OR Top 12 by Rank, Format, Owner 1996-97

$\begin{array}{lll}\text { Rank Station } & \text { Format } & \text { Owner }\end{array}$

\begin{tabular}{|ll|l|l|}
\hline 1 & KKRZ FM & CHR & Jacor \\
\hline 2 & KKCW FM & AC & Jacor \\
\hline 3 & KWJJ FM & Country & Fisher \\
\hline 4 & KXL AM & NTI & Alexander \\
\hline 5 & KUPL FM & Country & Amer. Radio Systems \\
\hline 6 & KEX AM & NTI & Jacor \\
\hline 7 & KKSN FM & Oldies & Sinclair \\
\hline 8 & KUFO FM & AOR & Amer. Radio Systems \\
\hline 9 & KGON FM & Classic Rock & Entercom \\
\hline 10 & KNRK FM & New Rock & Entercom \\
\hline 11 & KINK FM & AAA & EXCL \\
\hline 12 & KKJZ FM & Smooth Jazz & Amer. Radio Systems \\
\hline
\end{tabular}

CHR: Contemporary Hit Radio

AC: Adult Contemporary

NTI: News Talk Info

AOR: Album Oriented Rock

AAA: Adult Album Alternative

Note: This excludes public station OPB; no ratings data available for 1996-97.

Source: Arbitron Archives, Hargrett Rare Book \& Manuscript Library, U. of Georgia.

http://www.libs.uga.edu/hargrett/index.shtml 
Appendix E

Portland, OR Top 12 by Rank, Format, Owner, 2011

Rank Station Format Owner

\begin{tabular}{|ll|l|l|}
\hline 1 & KKCW FM & AC & Clear Channel \\
\hline 2 & KOPB FM $*$ & News/Talk & PUBLIC \\
\hline 3 & KLTH FM & Classic Hits & Clear Channel \\
\hline 4 & KKRZ FM & CHR & Clear Channel \\
\hline 5 & KUPL FM & Country & Alpha \\
\hline 6 & KFBW FM & Classic Rock & Clear Channel \\
\hline 6 & KGON FM & Classic Rock & Entercom \\
\hline 8 & KXJM FM & Rhythmic CHR & Clear Channel \\
\hline 9 & KINK FM & AAA & Alpha \\
\hline 10 & KWJJ FM & Country & Entercom \\
\hline 11 & KYCH FM & Variety Hits & Entercom \\
\hline 12 & KEX AM & News/Talk & AAA \\
\hline 13 & KNRK FM & & Entercom \\
\hline
\end{tabular}

CHR: Contemporary Hit Radio

AC: Adult Contemporary

AOR: Album Oriented Rock

AAA: Adult Album Alternative

*Note: Because my subject is commercial radio, I do not count public station KOPB.

Source: Arbitron http://www.arbitron.com/home/content.stm accessed June, 10, 2011 


\section{Appendix F}

\section{Radio Survey 2011}

*Note that responses are in red*

1. As part of my master's thesis at PSU concerning media policy, I am conducting this survey of broadcast news professionals who worked in Portland radio between 1986 and today.

Does this describe you? YES $=17$ (Negative responses to this question were omitted)

2. Please specify which years (between 1986 and 2011) you worked as a radio professional in Portland.

Of 17 respondents, all were employed during some years between $1986-2011$.

\begin{tabular}{|l|r|}
\hline Min & 4 \\
\hline Max & 25 \\
\hline Mean & 17.6875 \\
\hline
\end{tabular}

3. In your opinion, what are the most important roles local radio should play in a community?

\section{Respondents:}

1. Radio has the ability to inform listeners of news and events immediately. Although t.v. is changing, radio is still much more mobile and easier to accomplish. And unlike the internet, it is more genial.

Someone is communicating with you. You are a listener just as you listen to a storyteller around the campfire.

2. Conveying timely and essential information to a large audience, particularly during times of emergency. Elevating awareness of local issues, problems, opportunities, and solutions. Providing an opportunity for diverse voices to be heard. Enhancing the community's self-awareness and sense of place. All within the context of the station's mission of reaching a target audience and, for commercial stations, succeeding as a business.

\section{3. (no response)}

4. If there is any credence to the idea that the airwaves are public, a local radio operation receives a license to broadcast as a sort of "permission 
slip" to utilize a certain frequency on behalf of the people who truly own it - the public. Under the rubrics of this baseline truism, therefore, such stations are obligated to serve their public. Certainly, as a business, they must make a profit, but they must also devote a measurable (and considerable) amount of time to public services - announcements, programming, and news - with the sole purpose of informing and elevating public discourse. In this sense, local radio stations have a moral and ethical responsibility to act as "vox populi."

\section{5. (no response)}

6. To provide the fastest information to the public in the event of emergency or crisis. To provide the most up-to-date information on weather and traffic conditions for commuters. To bring the rest of the world to listeners' doorsteps.

7. Covering local news and issues, giving voices to people who might not otherwise be heard, giving local perspective on national and international issues.

8. 1) Fostering a sense of "community;" involvement with local issues, local needs, the local arts communities and charities; Those stations that provide music (AKA entertainment) have a responsibility to play to the demographics of their home community. 2) Give to the community, rather than squeeze the local audience and businesses for more dollars. 3) Provide creative programming, appropriate for community served. In other words, do not talk down or target lowest common denominator. Radio should help build the overall "creativity" of its home community.

9. 1.local news and information - done by trained professionals 2.public affairs programming that is produced locally; that addresses issues of public importance 3.entertainment that is compelling; locally orginated is a must for significant portion of the day 4.great local programming helps to define a place and give people a sense of place

10. Provide a wide range of news and information to our audience, including community events, arts and culture. Create unique programming for our local community.

11. Radio has the ability to connect to the individual listener to both inform and entertain. To maintain an audience, the information needs to be entertaining. Radio has the ability to pass along local news and issues while getting the audience to interact with those topics. This can apply to music and information based radio stations. Radio should play a vital role as a conduit to broadcast information to the general public. Emergency 
information is important during a crisis. Community news and issues are important on a daily basis.

12. Providing timely and accurate news and information.

13. Local commercial radio provides the community with the fastest most accurate information in the event of a large-scale emergency. Be it fire, volcanic eruption, earthquake, tsunami or a simple traffic tie-up, most people turn to radio first, which is appropriate.

14. It depends on the community. In Cannon Beach it should provide essential information on a real-time basis. In Portland there is a community of communities. We're a fragmented urban society so there is a multitude of roles for radio to play. If it hopes to survive in a free market environment, it's primary role is to attract enough listeners to make a profit and stay in business. Unless it's a philanthropic endeavor.

15. The role of local radio news should be to ascertain the most pressing issues and needs of a community and address them with thoughtful, timely, and balanced programming as well keeping on top of breaking local, national, and international news.

16. News radio should be a reflection of the community. It should provide a voice for the public. It should answer questions about what people are seeing in their communities. If there's smoke in the sky, if there's a traffic back up, we should tell listeners why. If there is a controversial topic, we should present both sides without drawing conclusions.

17. To inform citizens of breaking news in their communities, covering a broad spectrum of topics (political decisions, business news such as layoffs, natural/manmade disasters). Even with all the new media out there, I still think radio is the best source for fast-breaking news. To serve as a universally-accessible forum for disseminating ideas, encouraging public debate, and highlighting the cultural life an unique identity of a community through interviews, broadcast community events, editorials, live performances and call-in programs. 
4. As you see it, in terms of providing the public with an adequate source of local news/public affairs, Portland stations offer:

\begin{tabular}{|l|l|}
\hline Too much & 0 \\
\hline Right amount & 2 \\
\hline Not enough & 14 \\
\hline
\end{tabular}

5. In your professional estimation, have local stations increased, maintained, or reduced the amount of local news/public affairs in recent years?

\begin{tabular}{|l|r|}
\hline Increased & 0 \\
\hline Maintained & 1 \\
\hline Reduced & 16 \\
\hline
\end{tabular}

6. Some studies suggest less time is now being allocated for local news/public affairs on local radio. Do you think this is the case?

\begin{tabular}{|l|r|}
\hline Yes & 15 \\
\hline No & 1 \\
\hline
\end{tabular}

7. If yes, which of the following are reasons you think stations have reduced such programming? (Please rate on a scale of $1-10.1=$ Non-reason, $10=$ Major Reason.) Responses are tabulated below, in figures $7 \mathrm{a}-7 \mathrm{~d}$, followed by volunteered responses to e, "other."

a. Ownership efforts to reduce cost

b. Buy-outs by larger media companies

c. Audiences prefer non-news (entertainment)

d. People can get local news elsewhere (TV, Internet, etc.)

e. Other (please specify): 
Figure 7a

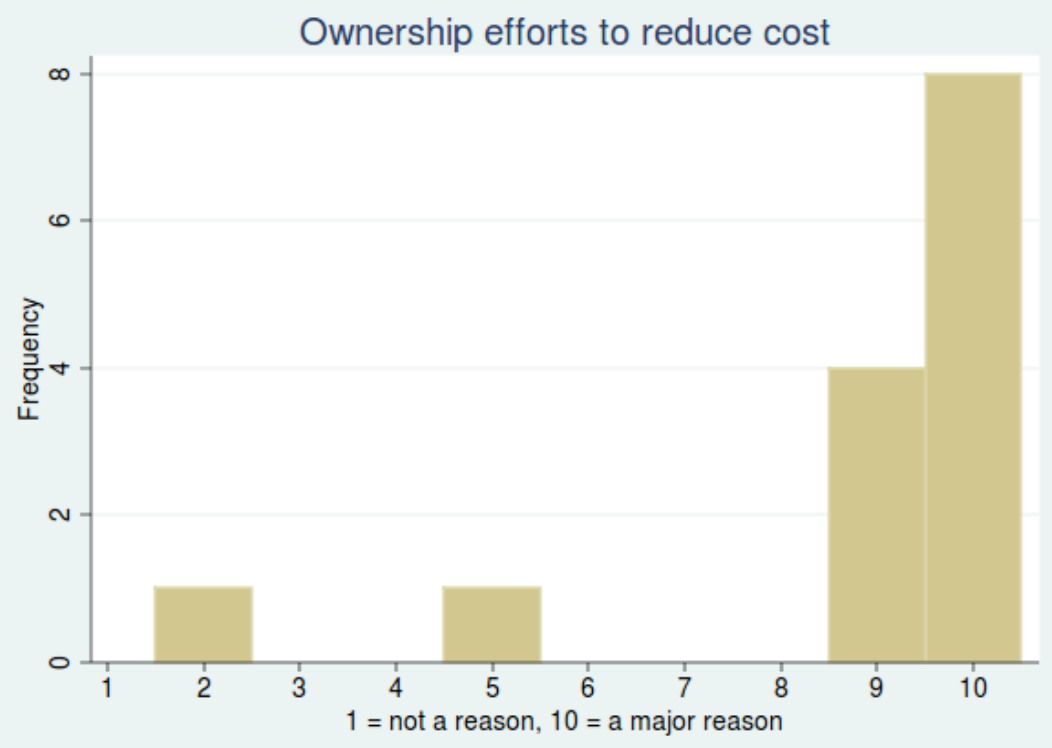

Figure $7 b$

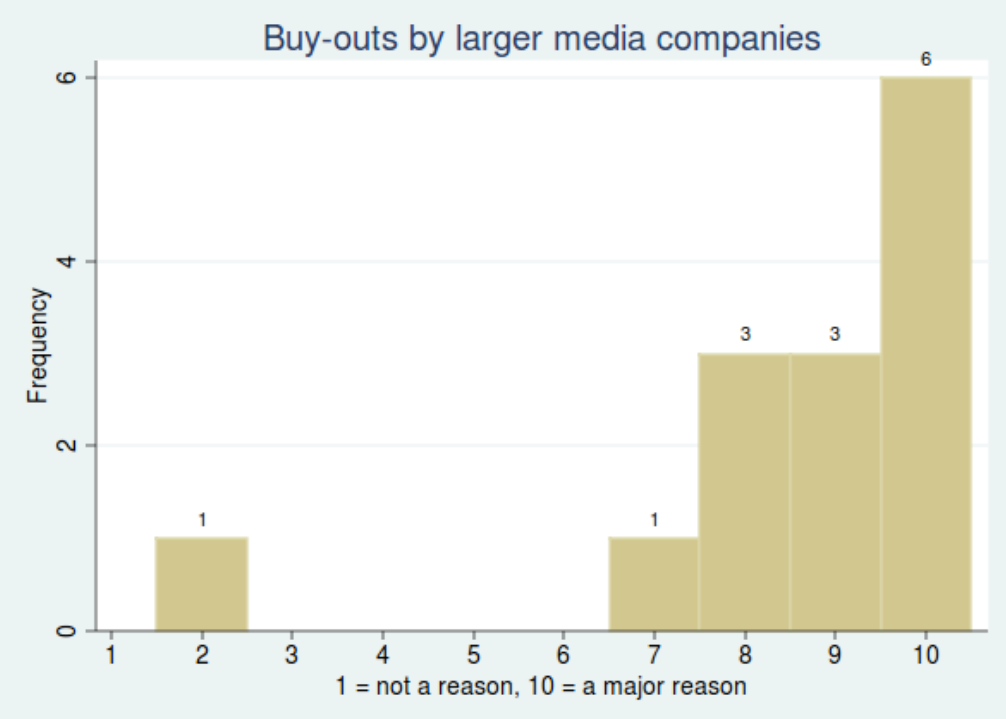


Figure 7c

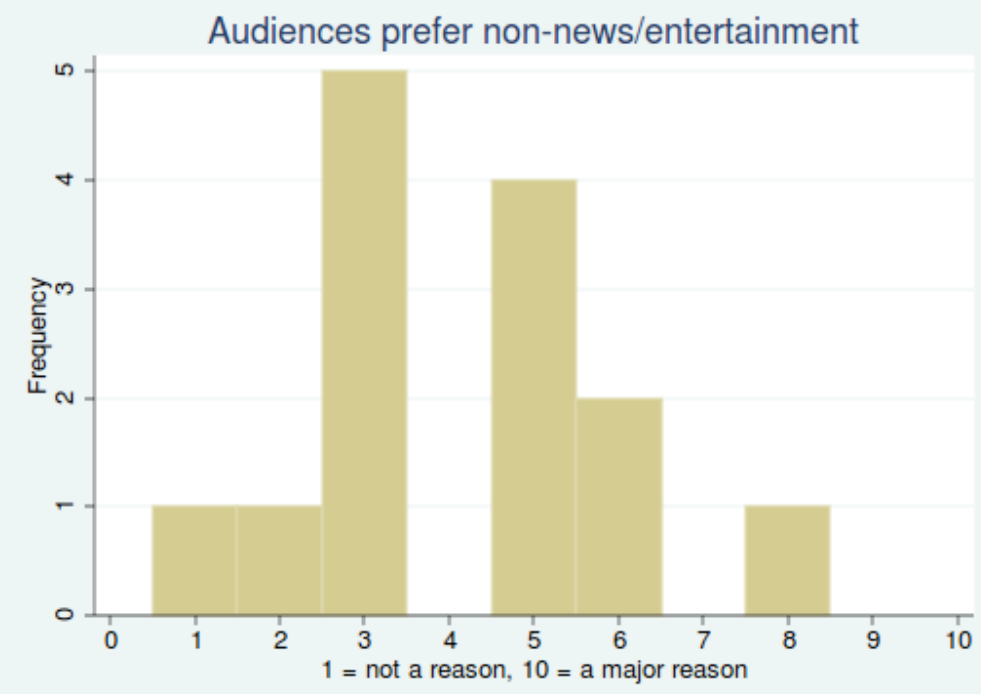

Figure $7 d$

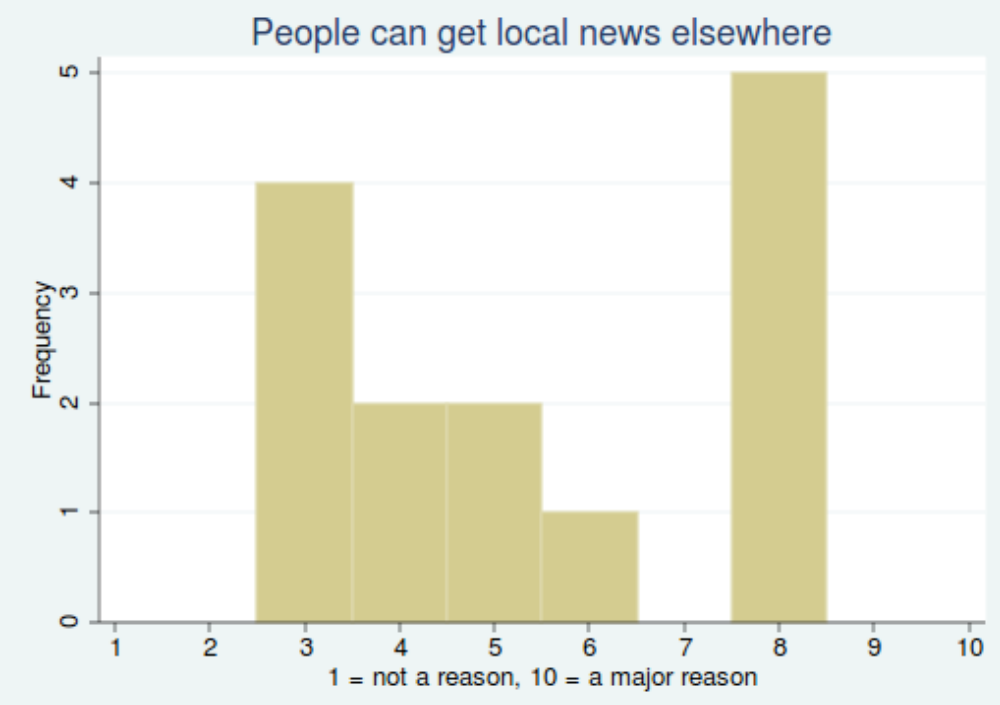


7e. Respondents who marked "other" offered the following as additional possible factors in the reduction of local news/public affairs on local commercial radio. (Listed here by respondent number.)

1. I think it's the popularity of talk radio that's reduced news programming. Many would call talk radio 'news and public affairs' and so they'd differ with my opinion.

2. Information is now fully a part of programming. If it increases audience share, it's there. If not, it's gone.

4. FCC deregulation has led to radio stations having no incentive to serve the public. Financial gain has become the only reason such stations exist today.

11. Music stations have reduced news and increased music to compete with music players, internet radio and other sources.

\section{Lack of imagination.}

Questions 8 - 14. Please rate how much you agree or disagree with the following statements: (On a scale from 1 to 10 , where $1=$ Strongly disagree, $5=$ neutral, $10=$ strongly agree) Responses are tabulated below, in figures $8-14$.

\begin{tabular}{|c|c|}
\hline 8 & $\begin{array}{l}\text { Radio is just like any other business, and should be able to profit in } \\
\text { the same way as any other business. }\end{array}$ \\
\hline 9 & $\begin{array}{l}\text { Because it uses public airwaves, radio is different from other } \\
\text { businesses. }\end{array}$ \\
\hline 10 & $\begin{array}{l}\text { I think we have plenty of choices for local news/public affairs news } \\
\text { on the radio. }\end{array}$ \\
\hline 11 & $\begin{array}{l}\text { Except for public broadcasting, local radio } \\
\text { reporting on important public issues is pretty limited }\end{array}$ \\
\hline 12 & $\begin{array}{l}\text { Radio programming should not be regulated. The public interest } \\
\text { should be determined only by ratings (how popular a program or } \\
\text { station is). }\end{array}$ \\
\hline 13 & $\begin{array}{l}\text { Radio stations should be required to air some programs that reflect } \\
\text { local concerns. }\end{array}$ \\
\hline 14 & $\begin{array}{l}\text { As a broadcast journalist, I feel my ability to communicate } \\
\text { important news subjects to my listening audience is limited in the } \\
\text { current media environment. }\end{array}$ \\
\hline
\end{tabular}


Figure 8

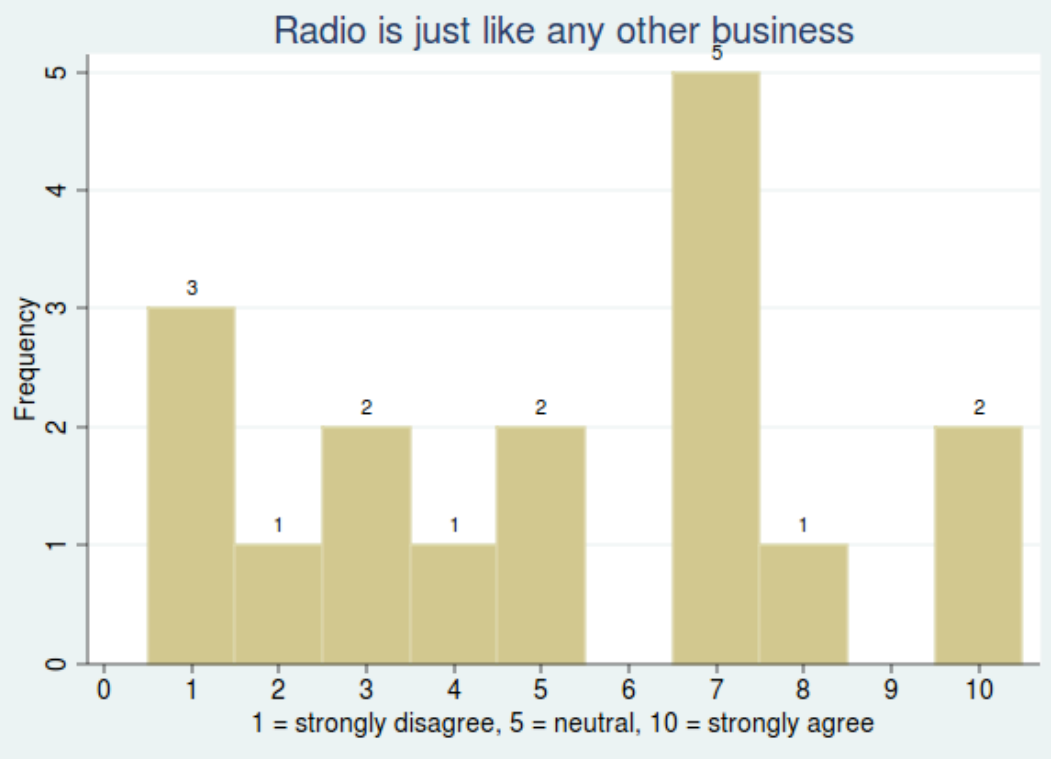

Figure 9

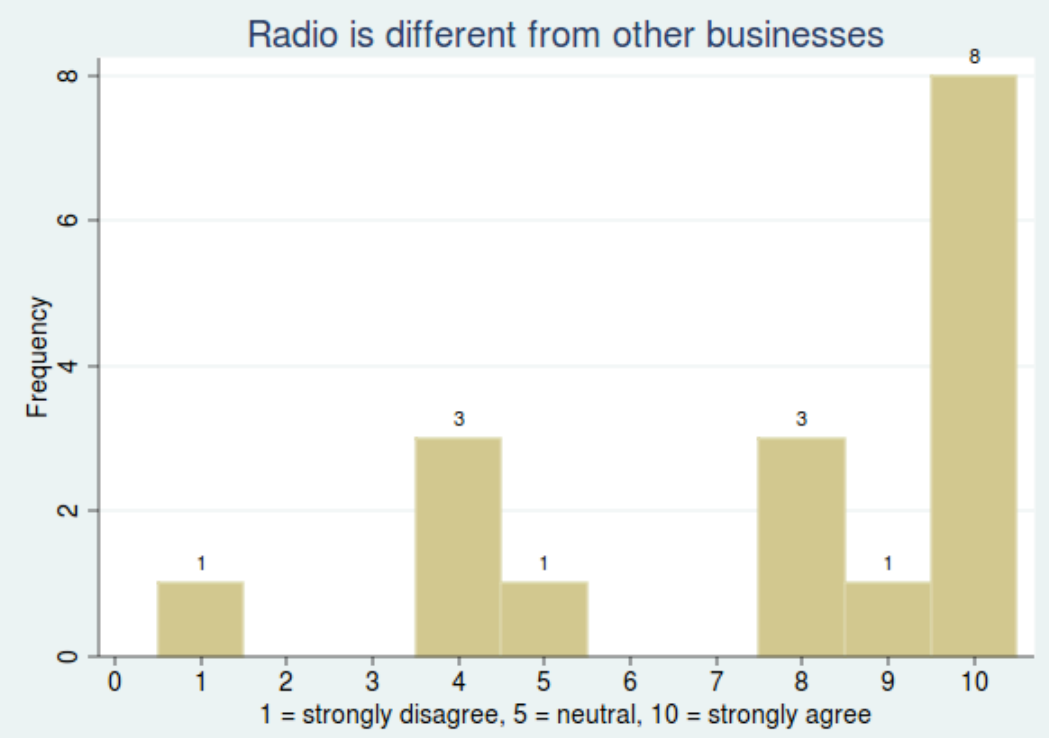


Figure 10

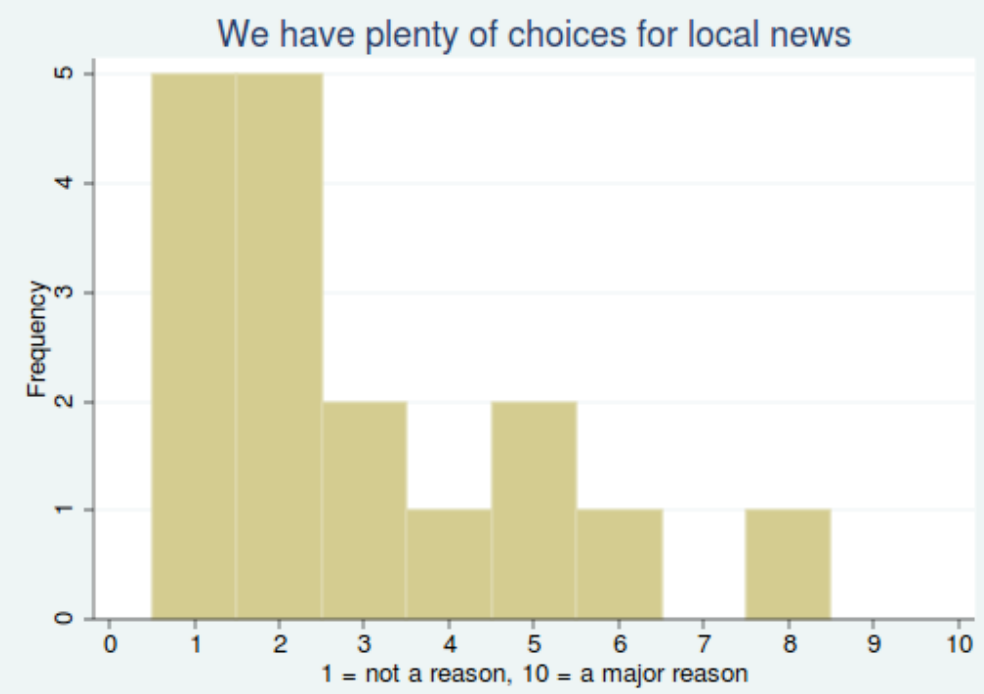

Figure 11

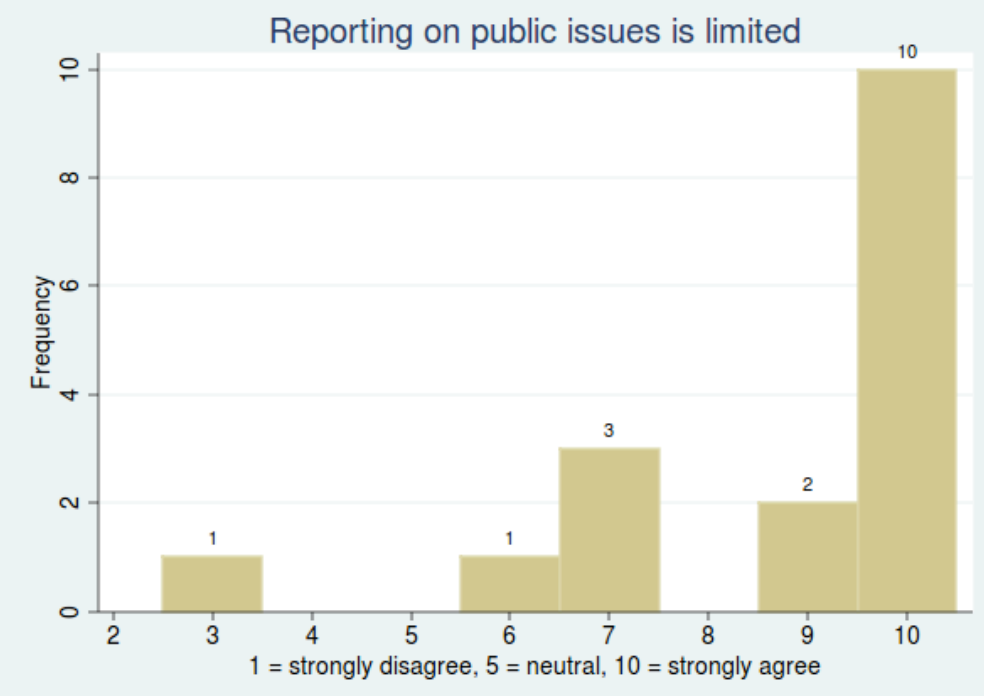


Figure 12

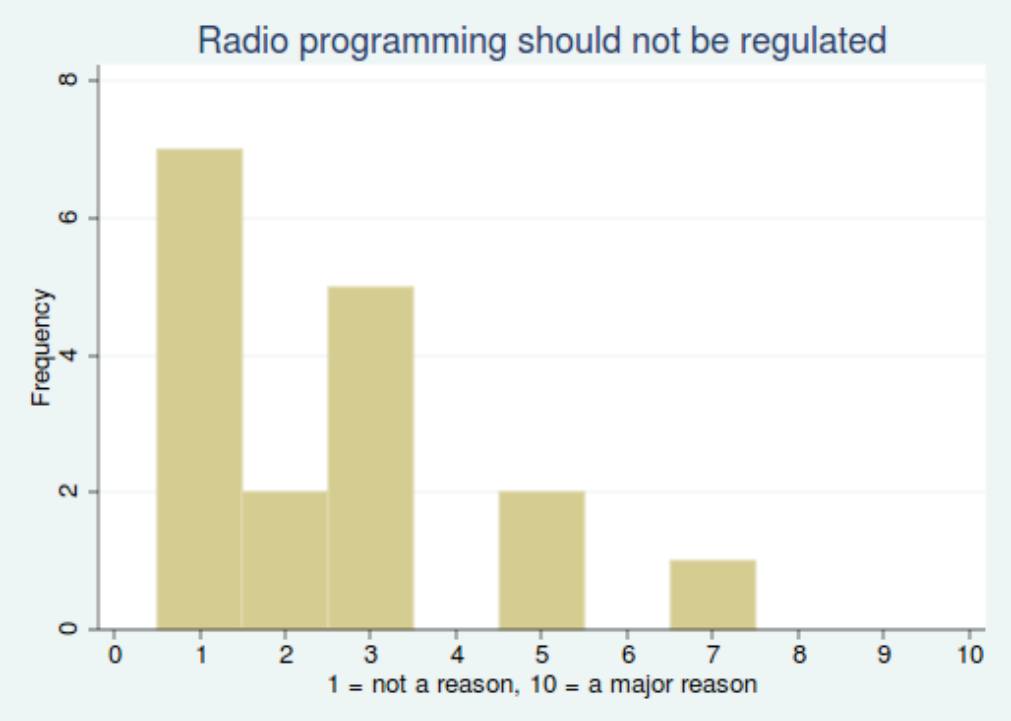

Figure 13

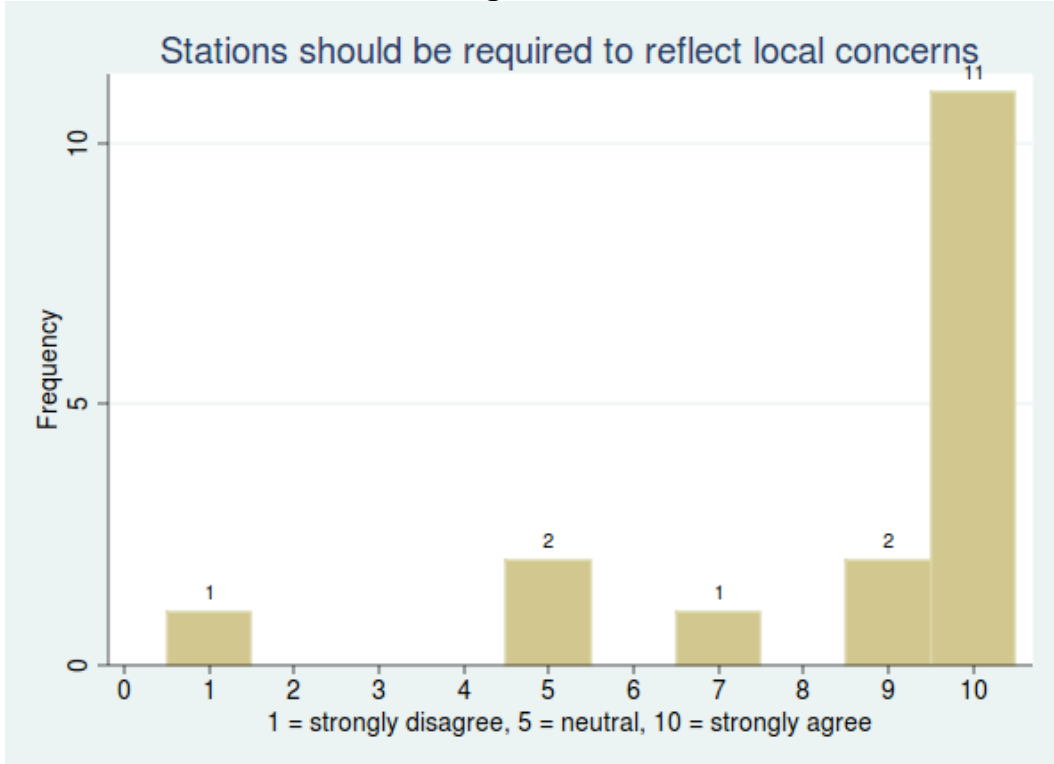


Figure 14

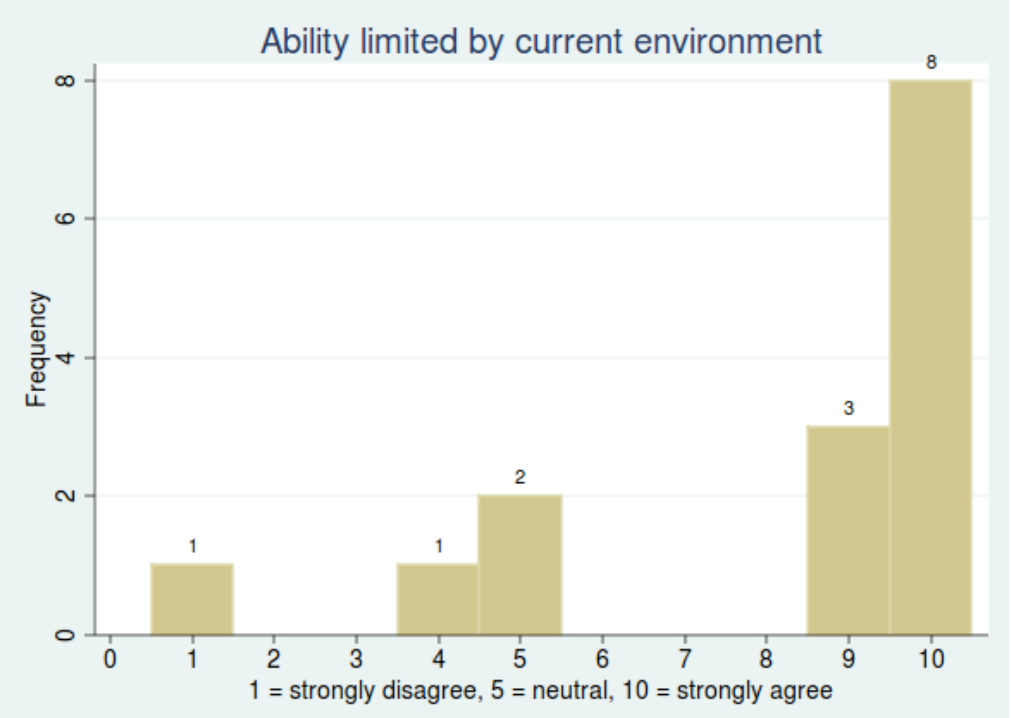

15. As an on-air radio employee, are/were your news/public affairs stories shared more with another station(s) in recent years?

Yes: 11

No: 5

16. As a staff member (on or off the air) do/did you use more shared content (produced elsewhere in your company or parent company) in recent years?

Yes: 12

No: 3

17. What are your thoughts on the public service responsibilities of local radio? (Responses are listed in red below, by respondent number. Note that station names were omitted if they risked revealing the respondent's identity.)

1. Response: I am an avid NPR listener now. I rarely tune in to another station anymore - because I just prefer to stick with the reliability of NPR and I don't really have the time to test out or muddle though other stations. I worked for $\mathrm{K}$ and thought they were very good and they probably still are but there's a lot to sit through and I am pretty much a car listener only I don't want to sit through commercials or "stuff" when I have such a limited amount of listening time. That's true for $\mathrm{K}_{\text {_ }}$ as well where I also worked. (Those are the only two stations where I worked. I think we did a great job at both places and I loved what i/we put on the air. I should say also as an employee of $\mathrm{K}$ I also did weekend radio hits for $\mathrm{K}$ since they were our news partner for a while.) I am attracted to radio 
stations that do a good job with news and public affairs, but I also believe in free enterprise and with everything else out there, I'm not sure it's realistic to regulate radio anymore.

2. Smart broadcasters, like any business, understand that they benefit by playing a role in the community beyond squeezing out the greatest possible profit. Successful commercial stations are run by local management and staff who care about the community they live in. When a top-rated morning show raises awareness and then delivers a large turnout to a fundraising event for an important cause, it's not because they're required to by regulation. I've seen for decades how regulatory requirements usually result in only a minimal level of community service programming. And if stations were required to present $\mathrm{x}$ amount of PA programming, it seems very plain that staff won't be added--the duty will be assigned to one of the few remaining employees who've survived budget cuts, and they'll be spread thinner yet.

\section{3. (no response)}

4. Deregulation has created the McDonald-ization of modern broadcasting. This trend, which began to appear increasingly in the 1970s with the birth of the broadcast consulting industry, has ossified completely over the past three decades with the takeover of the airwaves by a handful of large corporations. What once required literate, erudite, thoughtful and relatively objective programmers and news departments has been desiccated into an almost lifeless husk of banality. Vital, lively and stimulating examination of local issues is the a priori responsibility of every local broadcaster, and this has simply disappeared from the broadcasting lexicon. Issues that literally speak to the heart of a society's ability to survive, much less prosper - its educational system, forms of politics and governance, environmental concerns, to name but a few - are apparently now considered too boring or complex for local media to address. A syndrome has evolved in which the public, long denied civil discourse and the catalyst for thoughtful introspection, has increasingly become accustomed to a broadcast diet of intellectual pablum. This, in turn, creates the perception among station owners that this is what the public really desires. Content is diluted further still, and the end result is "news" and public affairs programming barely recognizable as such. Were he alive to witness it, Edward R. Murrow would be in agony.

5. Public services messages, in short form, are no longer run on stations that I know of unless there's some kind of commercial buy included either by the charity or a big name sponsor. There are private charity events that all stations get involved in within a calendar year, but it seems mostly 
about what other sponsors get involved or how big the event is so the station can make an impression in the community. It's as though the marketing of a station has become what charity event can we be seen doing in front of the most people. Nothing wrong with that, but the smaller charities, and little events pretty much are ignored, or put on an event list on a website. Station ratings in the world of PPM* are split within such a narrow margin in any demographic, that the trend has been to not talk much, play more music, and hope for the best. Then you have the all talk stations, which are also entertainment, and not balanced in terms of political slant. This hasn't done anyone any good. Fair and balanced presentation of issues is the only way to make responsible decisions. I think it's just good radio to be involved with the community, and all the events, music, festivals, and fundraisers that are important to the audience. It's too bad that it takes regulation to make most stations do the right thing. Running the same local PSA show on a cluster of stations early in the morning on Sunday, isn't really serving the community.

\section{*PPM refers to Portable People Meter, an Arbitron ratings device worn by research volunteers to measure time spent listening. (See Appendix H.)}

6. I believe radio stations should be required to air a certain number of hours to public service programming. If it is not required, as history has shown us, it simply won't be done.

7. Because they use public resources they need to be more accountable to the public - not in what they say but in what they cover. I am a dinosaur. I believe in the fairness doctrine, I believe in children's content, I believe in specifying a certain amount of local content. I think that makes me a commie pinko fascist Nazi. So be it.

8. At the last "cluster" of stations I worked for, I was given carte blanche to cover local issues in an absolutely nonpartisan manner. i.e. both sides of issues, particularly during election coverage. The company that purchased most of these stations only provides public service programs that reflect its partisan mission. This is absolutely counter to the very few public service requirements that remain. The FCC has gutted public service mandates because a handful of big corporations own almost all the radio stations in the country. Consequently, the FCC serves these big corporations rather than the public. There is, quite frankly, nothing on the commercial airwaves in the greater Portland area that lives up to the "service" in public service. Only OPB and KBOO offer any balanced coverage, and KBOO leans toward the left. Public service and news should help listeners participate in our cherished free and open society... bring them into the "process" of democracy, so to speak; and help them make informed decisions in all areas of political and community discourse. The 
current state of public service on-air in Portland suggests that 1) only entertainment is important and 2) that a station should indoctrinate listeners to its political agenda.

9. 1.Radio has unique story-telling capability, with a one-on-one, personal touch. People say, "that's my radio station." Whereas, you don't hear people say, "Channel 8, that's my favorite TV station." Same for newspaper. Nothing connects to the degree that radio can. 2.Given radio's story-telling capability and highly personalized connectivity, radio has an obligation to create MEANINGFUL and INSIGHTFUL news and public service programs. Otherwise, it's a waste of a tremendous resource. 3.It's interesting that KOPB, which has one of the largest weekly cume* numbers in the market, produces the best public service and news programming. 4.Commercial broadcasters are missing out on the opportunity for bigger ratings and profits by abdicating their responsibility to have better news and public affairs programming.

\section{Note: "Cume" refers to Arbitron's estimation as to how many unique listeners (among target groups) are tuned in during a given period of time for at least five minutes.}

10. Local media resources have been drastically reduced since the deregulation of radio. The consolidation of radio resulted in drastic staff reductions and eliminated quality local. The station I have worked at for 23 years went from a thriving local business that provided above average wages and excellent benefits to its staff to a corporate cash cow in a matter of a few brief years. Today, our main focus is increasing revenue and keeping investors happy. We are often reminded that we all work for the sales department.

11. Radio needs to serve the local community, as such it has the responsibility to provide information that meets the needs of the community. The product must attract an audience, because without listeners, what good is the information? Public service responsibilities can be met in many ways, but the variety of issues must be diverse. It includes, but is not limited to, local government, schools, community groups and efforts, emergency preparation and emergency coverage. Radio has the responsibility to bring into the community discussion of issues that might normally be ignored.

12. Radio stations are licensed to use the airwaves by the federal government. Because of that, they should allocate a percentage of their broadcast day to serve the public interest with topical news and information. 
13. I think there is too little emphasis/caring about the public service responsibilities. But the lack of content and time devoted reflects that the BUSINESS of radio is dollar-driven. I work at the Alpha Broadcasting radio cluster and we are (arguably) the front-running servers of need-toknow information. On a daily basis we seek out informed experts to tell our audience what is happening behind the scenes of public events. When we believe the public needs to know WHY someone/something is happening as it is, we try very hard to find someone with insight. We hold at least three meetings a day to discuss story ideas and possible approaches to stories, I expect we are unique in that regard. I believe that our news product is on a par with any station in the country and THAT is what a radio station should strive to achieve. Otherwise it is just a purveyor of advertising without the content that the listeners deserve from a station granted access to the airwaves.

14. Mandating public service programming content is appropriate as the price broadcasters must pay for a piece of the spectrum of the public air wave spectrum. Controlling said content is not. Based on my own experience, the most well-intentioned public service programming will remain relegated to the off hours on non-public broadcasting stations unless broadcasters figure out a way to make it entertaining. Doing so is extremely difficult if not impossible. People mostly turn on the radio to be entertained and informed, not to become better citizens.

15. See answer to question 3.

16. News radio has a better opportunity than music radio to address public service responsibilities through our news content. However, with limited staffing, more quick and frequent newscasts, and growing responsibilities on our websites, it is increasingly difficult to really dig into topics. Aside from that, we must do our best to reflect public issues in the community. Mandating this as part of a radio license is an effective way to do this.

17. The airwaves belong to the public. Radio stations (commercial and public) have them on loan from us. I do not object to radio station owners making a profit from the public airwaves (any more than I object to trucking companies profiting because they use public highways). Even public radio has to make a "profit" to remain solvent". But I do think being allowed to profit from the public airwaves implies some responsibility for using some of that airtime to inform/educate the public about local issues/concerns. In an era of shrinking ad revenues and an explosion of media choices, I think a good deal of this responsibility has been cast aside in the struggle to keep radio stations alive as businesses. I don't know how to fix that. But I think whatever the business climate, 
radio stations need (even in a limited way) to be part of the public life of their communities through their newscasts, interview programs, and broadcast public forums. 


\section{Appendix G}

Spike in Acquisitions - Radio Stations Nationwide

Acquisitions $=$ The number of radio stations changing hands through purchase, merger, swap, or other transfer in a given year.

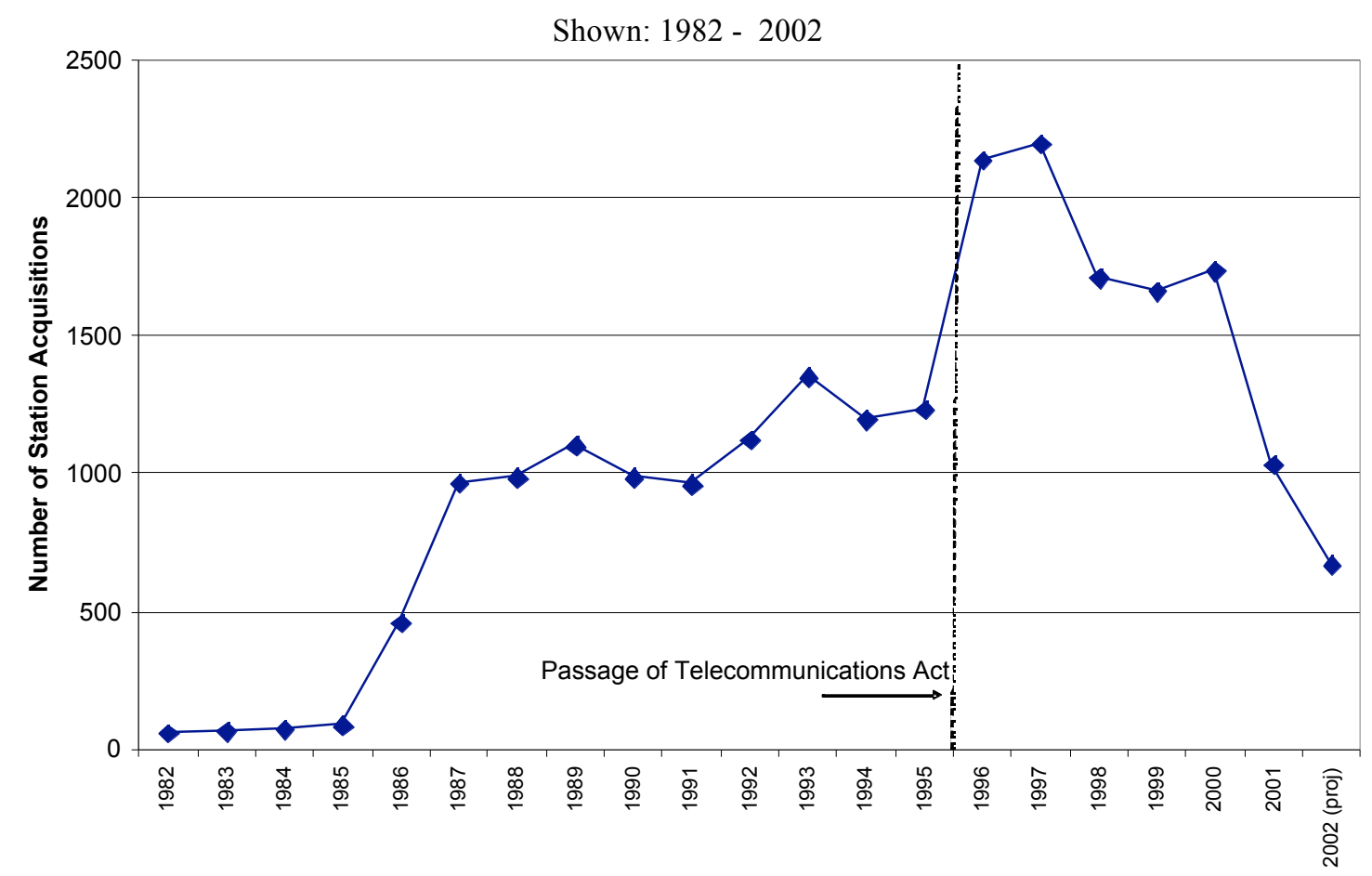

A considerable increase in station acquisitions occurred following the 1996 Telecommunications Act.

Source: DiCola and Thomson 2002, p. 20 


\section{Appendix $\mathrm{H}$}

\section{Portable People Meter}

According to Arbitron's "Guide to Understanding and using PPM Data," available at the Arbitron website:

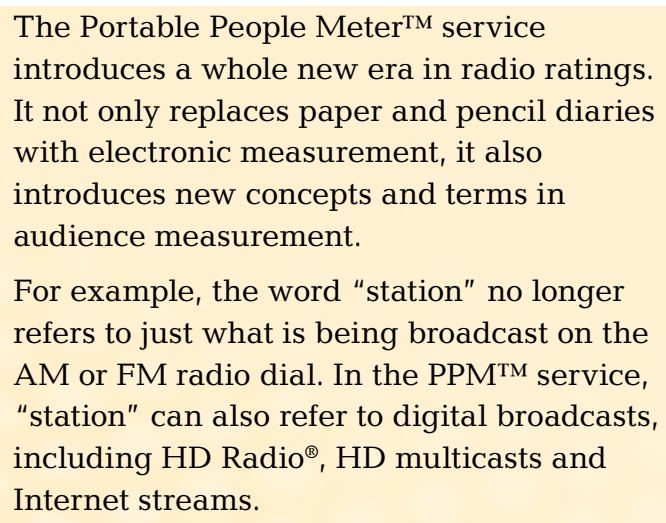

A PPM is a pager-like device worn by research volunteers ("panelists"), which picks up "unique inaudible codes" embedded in audio signals emitted by broadcast and Internet streams (from online radio stations).

Source: Arbitron http://www.arbitron.com/portable people meters/home.htm

Note: Arbitron data has previously aggregated data for people 12 years and older shown in ratings data as "12+" although, since 2007, the service has expanded to include six-year-olds, so that much Arbitron data is now expressed as " $6+$. ." Per Arbitron spokesman, personal email. 
Appendix I

\section{Employee Data per SEC Filings}

\section{Clear Channel}

Clear Channel had 2,377 radio employees and 86 radio stations in 1996, per SEC 10-K filing for fiscal year 1996, filed March 31, 1997. Dividing the number of employees by the number of stations, I found a per-station employee average of 27.6.

Source: http://www.sec.gov/Archives/edgar/data/739708/0000739708-97-000006.txt;

Because of business reorganization, federal filings no longer break out radio employees. So, to determine the number of radio employees, I accessed:

CC Outdoor (Clear Channel's Outdoor Billboard and Advertising business)

SEC 10-K data, found at

http://www.sec.gov/Archives/edgar/data/1334978/000119312510058241/d10k.htm

as of March 10, 2010, had 1,996 US billboard/advertising employees.

I also accessed Clear Channel Communications (including broadcast and billboard/advertising operations) shows 14,980 domestic employees and 894 radio stations.

SEC 10-K data, fiscal year 2009, found at:

http://www.sec.gov/Archives/edgar/data/739708/000119312510058288/d10k.htm

By subtracting the number of billboard/advertising workers $(1,996)$ from the total number of Clear Channel domestic workers (14,980), I determined the company had 12,984 radio employees in 2009.

\footnotetext{
14,980

$-1,996$

$=\overline{12,984}$ radio employees 2009
}

Dividing the number of broadcast employees $(12,984)$ by the number of stations $(894)$, I found the per-station average number of employees for 2009 was 14.5 .

\section{Entercom}

Entercom employed 684 full-time and 250 part-time workers in 1998 (the oldest year for which SEC data was available), per SEC S-1 filing Aug. 13, 1998. With 41 stations, Entercom employed an average of 16.68 full-time and 6.1 part-time workers.

Source: http://www.sec.gov/Archives/edgar/data/1067837/0000893220-98-001351.txt 
In November 2009, SEC data shows Entercom with 110 stations, 1,560 full-time, and 750 part-time workers, a per-station average of 14.18 full-time and 6.8 part-time employees.

Source: http://www.sec.gov/Archives/edgar/data/1067837/000110465910014263/a09-35761_110k.htm 
Appendix J - KGON

News, Public Affair, PSAs 1998, 2011

$\underline{\text { News }}$

KGON news calculations - National News 1998

News during Morning Show, between 5:00 - 10:00 AM weekdays: National news =60 seconds per hour $\mathrm{x} 5$ hours $=300$ seconds $(5 \mathrm{~min}$.) per day. $5 \times 5$ days $=25$ national news minutes per week $x 13$ weeks $=325$ min. per quarter.

\section{Local News 1998}

Local news $=180$ seconds per hour $x 5$ hours $=900$ seconds $(15 \mathrm{~min}$. $)$ per day.

$15 \times 5$ days $=75$ local news minutes per week $\times 13$ weeks $=975$ min. per quarter.

\section{National News 2011}

News during Morning Show, between 5:00 - 10:00 AM weekdays: From Los Angeles = 105 seconds per hour $x 5$ hours $=525$ seconds $(8.75 \mathrm{~min}$. $)$ per day.

$8.75 \times 5$ days $=43.75$ national news minutes per week x 13 weeks $=569$ min. per quarter.

\section{Local News 2011}

No local news is presented, aside from occasional traffic and weather announcements.

\section{Public Affairs}

KGON public affairs calculations - National Public Affairs 1998

Conversation, a 60 min. national public affairs program ran at 5:00 AM Sunday mornings. $60 \times 13$ weeks $=780 \mathrm{~min}$. national public affairs min. quarterly.

\section{Local PA 1998}

KGON presented a one-hour local public affairs program, Metroscope, at 6:00 AM Sundays mornings. $60 \mathrm{~min}$. 13 weeks $=780 \mathrm{~min}$. local PA.

\section{National PA 2011}

KGON presented two nationally syndicated public affairs shows, Viewpoint and Radio Health Journal, 7:00 - 8:00 AM, Sundays. Each program ran an average of 25 min. $=50$ min. per week x 13 weeks $=650$ min. national public affairs programming per quarter. 


\section{Local PA 2011}

KGON presented a local public affairs program, Metroscope, which ran weekly, 6:00 7:00 AM, Sundays. Each program ran 50 min. $x 13$ weeks $=650$ local public affairs min. per quarter.

Public Service Announcements

\section{National PSAs 1998}

Multiple PSAs ran, daytime (5:00 AM - 11:00 PM) = 2.25 min. per quarter.

Multiple PSAs ran nighttime $(11: 00 \mathrm{PM}-$ 5:00 AM) $=99$ min. per quarter.

\section{Local PSAs 1998}

Multiple PSAs ran - all daytime $=7.83$ min. per quarter. See samples, next page.**

\section{National PSAs 2011}

KGON's treatment of public service announcements has changed. For 2011, rather than numerous, brief PSAs, the station focuses promotional announcements around fewer, usually larger, station-sponsored events. "So, in terms of the old school :15 or :30 [second] PSA, those are long gone. Now, they are promoting an event around a charity. I think we have that covered in the Marketing and Traffic departments" (personal email).

Such events are sometimes, but not always, linked to local business sponsors.

For the first quarter of 2011, for example, KGON conducted a March of Dimes promotion, with 50 on-air "mentions."

\section{Local PSAs 2011}

As with national PSAs, KGON's local public service now revolves around specific charitable events - some sponsored by local businesses; others, championed by individual station employees. "Rock'tion," a benefit for a girls music camp, for example, was a key event during the 2011 first quarter, with 60 on-air mentions.

Source: http://blogs.kgon.com/irisharrison/2009/09/02/the-history-of-kgona-work-in-progress/ and personal emails with current or former KGON staff. 
Local PSA samples, 1998:

DOMESTIC VIOLENCE HOTLINE $\quad 1 / 15 / 48$ IF YOU ARE A VICTIM OF DOMESTIC VIOLENCE OR KNOW SOMEONE THAT NEEDS HELP FINDING SHELTER OR $2 A 78$ OTHER SERVICES, CALL ME AT 733-KGON AND WE CAN PROVIDE YOU WITH NAMES OF AGENCIES AND THEIR PHONE NUMBERS.

Domestic Violence Hotline 1-800-787-3224

Portland Women's Crisis Line 235-5333

Bradley Angle House 281-3540

STEPFAMILY ASSOCIATION OF AMERICA FOR INFORMATION AND OTHER HELP ON BEING A STEPFAMILY, CALL ME AT 733-KGON.

(227-4166 OR 1-800-735-0329)

OREGON DONOR PROGRAM

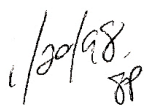

FOR INFORMATION ON THE OREGON DONOR PROGRAM OR TO GET A DONOR CARD CALL ME AT 733-KGON. (494-7888 OR 1-800-452-1369)

OREGON STATE UNIVERSITY OSU'S EXTENSION SERVICE OFFERS MATERIALS ON PARENTING. CALL ME AT 733-KGON FOR THE INFORMATION.

(737-2513)

OREGON ASSOC. FOR LEARNING DISABILITIES PARENTS OF CHILDREN WITH LEARNING DISABILITIES CAN GET INFORMATION ON SUPPORT GROUPS AND SERVICES. CALL ME AT 733-KGON FOR MORE INFORMATION.

(229-4439)

$318 \% 6$ PARENTING SKILLS CENTER THE PARENTING SKILLS CENTER IS SET UP TO ANSWER QUESTIONS, PROVIDE HELP AND PREVENT CHILD ABUSE... CALL ME AT 733-KGON TO GET THEIR ADDRESS AND PHONE NUMBER.

(901 S.E. OAK, SUITE 105 PORTLAND 235-5504)

Source: KGON station public file, viewed April 15, 2011. 
Appendix K - KWJJ

News, Public Affair, PSAs 1998, 2011

$\underline{\text { News }}$

National News 1998

News during Morning Show: estimated at approximately three minutes on the hour and half-hour between 5:00 - 9:00 (nine newscasts), for a total of $27 \mathrm{~min}$. of news per morning, of which about 9:00 minutes was national. For the week, $45 \mathrm{~min}$. of national news $\mathrm{x} 13$ weeks $=585$ minutes per quarter.

\section{Local News 1998}

Each newscast contained another estimated two minutes of local news, for $18 \mathrm{~min}$. local news per morning, or $90 \mathrm{~min}$. per week. 90 x 13 weeks $=1,170 \mathrm{~min}$. local news quarterly.

\section{National News 2011}

Both number and length of newscast were lower in 2011. Newscasts were estimated at one minute, twice per hour for three hours, 6:00 - 9:00 AM, for a total of seven minutes daily, or 35 min. per week. Of that, an estimated 25 percent focused on national news, 8.75 min. per week x 13 weeks $=113.75$ min. per quarter.

\section{Local News 2011}

Since 75 percent of the remaining news minutes were local $=26.25 \mathrm{~min}$. per week $\mathrm{x} 13$ weeks $=341.25 \mathrm{~min}$. local news minutes per week.

Public Affairs

\section{National Public Affairs 1998}

KWJJ's public affairs programming was local in 1998.

\section{Local PA 1998}

KWJJ offered a 30 minute local public affairs show, Metro Magazine, Sundays, 5:30 AM. 30 min. x 13 weeks $=390$. 


\section{National PA 2011}

KWJJ presented two nationally syndicated public affairs shows, Viewpoint and Radio Health Journal, the same shows that were aired on KGON. Instead of early Sunday morning (KGON), they ran on Sunday nights (KWJJ), 11:00 - Midnight. Each program ran an average of $25 \mathrm{~min} .=50 \mathrm{~min}$. per week $\mathrm{x} 13$ weeks $=650 \mathrm{~min}$. national public affairs programming per quarter.

\section{Local PA 2011}

KWJJ presented a local public affairs program, Metroscope, the same program aired on KGON. Again, instead of a Sunday morning schedule (KGON), Metroscope ran weekly, 10:00 - 11:00 PM, Sundays. Each program ran 50 min. $\times 13$ weeks $=650$ local public affairs min. per quarter.

\section{Public Service Announcements}

\section{National PSAs 1998}

KWJJ's were generally local.

\section{Local PSAs 1998}

KWJJ ran an average of seven 20-second PSAs per weekday morning $=140 \mathrm{sec}$. per day x 5 days each week $=700 \mathrm{sec}$. $(1.6 \mathrm{~min}$.) per week $\mathrm{x} 13$ weeks $=151.6$ PSA min. per quarter. See PSA samples next page.**

\section{National PSAs 2011}

If events listed for 2011, first quarter, are typical, KWJJ's PSAs are generally local.

\section{Local PSAs 2011}

Like KGON, KWJJ's local public service now revolves around specific charitable events - some sponsored by local businesses; others, championed by individual station employees. For example, for Q1 2011, the station gave 25 on-air announcements for a local benefit concert, and additional announcements promoting a benefit running event. See sample next page.** 


\section{KWJJ Sample PSAs - Compare:}

1998: 3 days

$1 / 27 / 98$

1. Richard Underwood Jr. Spaghetti Feed fund raiser

2. Seaside Chamber of Commerce Chocolate and Cotree

Lovers Festival

3. OHSU lecture "Men's Health Care, Its A Guy Thing."

4. March of Dimes -- Folic Acid

5. American Red Cross blood donations

6. World Forestry Center photo gallery series

7. Valley Catholic School Basketball Coach meet

1/28/98 1. OR. Tax check-off for Alzheimer's.

2. Adult Survivors of Childhood Trauma lecture

3. American Optometric Association :"Vision USA."

4. Seaside Chamber of Commerce Chocolate and Coffee Lovers

Festival.

5. Richard Underwood Jr. Spaghetti feed fund raiser.

6. Toastmasters Club of America.

1/29/98 1. Tualatin Valley Fire \& Rescue CPR Training.

2. Or. Tax Check-off for Child Abuse

3. OHSU lecture "Men's Health Care, Its a Guy Thing."

4. American Optometric Association "Vision USA."

5. Or. Tax Check-off for Alzheimer's

6. Seaside Chamber of Commerce Chocolate \& Coffee Lovers

Festival

\section{1: 91 days}

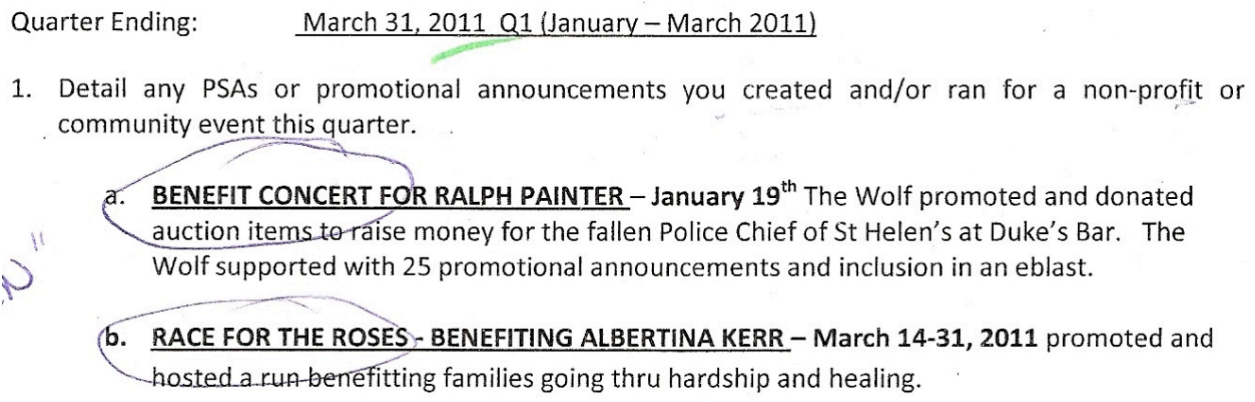

Source: KWJJ Public Files, viewed April 15, 2011. 
Appendix L

KOPB Radio Ratings 1997 - 2009

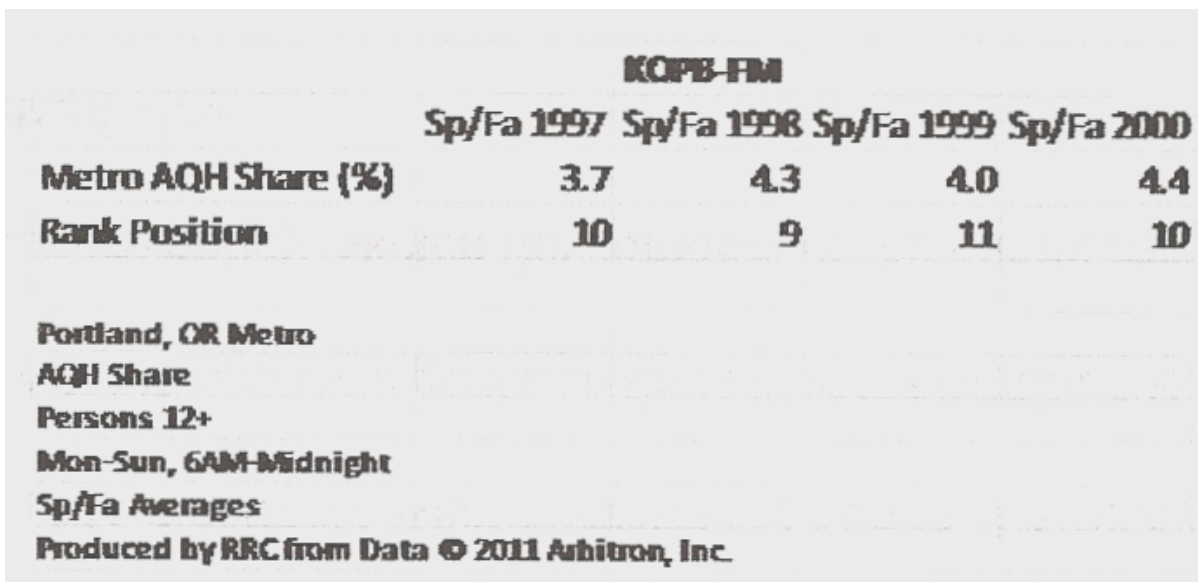

\begin{tabular}{|c|c|c|c|c|c|c|c|c|c|}
\hline & & & & & KOPB-FM & & & & \\
\hline & $5 p / F a 2001$ & Sp/Fa 2002: & Sp/Fa 2003: & Sp/Fa 2004 & 4 5p/Fa 2005 & 5p/Fa 2006 & $5 p / F a 2007$ & Sp/Fa 2008 & Spring $200^{*}$ \\
\hline Metro AQH Share & $\mathbf{6 . 0}$ & 5.6 & $\mathbf{6 . 1}$ & 6.5 & $5 \quad 6.7$ & 5.9 & $\mathbf{6 . 2}$ & 6.7 & 6.4 \\
\hline Rark Position & $\mathbf{2}$ & $\mathbf{2}$ & $\mathbf{1}$ & $\mathbf{1}$ & $\mathbf{1}$ & $\mathbf{3}$ & $\mathbf{2}$ & $\mathbf{1}$ & 1 \\
\hline & & & & & & & & & \\
\hline \multicolumn{10}{|l|}{ Pontland, OR Metro } \\
\hline \multicolumn{10}{|l|}{ ACH Share } \\
\hline \multicolumn{10}{|c|}{\begin{tabular}{|l|l|l|l} 
Persons 12+ & \\
\end{tabular}} \\
\hline \multicolumn{10}{|c|}{ Mon-SUn, Gaw Midhight } \\
\hline \multicolumn{10}{|c|}{ Sp/fa Averages ( +2009 is not aneraged as there is no Fa09 diay sumey) } \\
\hline Prochuced by Rax friom & Data $920011 \mathrm{~A}$ & Abitton, Inx. & & & & & & & \\
\hline
\end{tabular}

As shown here, KOPB's market ranking hovered around $10^{\text {th }}$ place in the late $1990 \mathrm{~s}$. It jumped up in the ratings in 2001, where it remained consistently in the first or second position.

Source: Radio Research Consortium, www. RRConline.org 


\author{
Appendix M \\ Shared Public Affairs Programs on Portland Radio
}

(Sundays, First Quarter, 2011)

\title{
Metroscope Viewpoints $\quad \underline{\text { Radio Health Journal Sunday Magazine }}$
}

Entercom Stations

\begin{tabular}{|c|c|c|c|c|}
\hline KFXX 1080 & 10:00 PM & 11:00 PM & 11:30 PM & ---- \\
\hline KNRK 94.7 & 6:00 AM & 7:00 AM & 7:30 AM & ---- \\
\hline KWJJ 99.5 & 10:00 PM & 11:00 PM & 11:30 PM & ---- \\
\hline КYCH 97.1 & 7:00 AM & $6: 30 \mathrm{AM}$ & 6:00 AM & ---- \\
\hline KRSK 105.1 & 7:00 AM & 10:00 PM & 10:30 PM & ---- \\
\hline KGON 92.3 & 6:00 AM & 7:30 AM & 7:00 AM & ---- \\
\hline \multicolumn{5}{|c|}{ Clear Channel Stations } \\
\hline KKRZ 100.3 & ---- & ------ & ---- & 7:00 AM \\
\hline KKCW 103.3 & --- & 10:30 PM & --- & 10:00 PM \\
\hline KFBW 105.9 & --- & 7:30 AM & --- & 7:00 AM \\
\hline KLTH 106.7 & ---- & 7:30 AM & --- & 7:00 AM \\
\hline KXJM 107.5 & ---- & 7:30 AM & ---- & 7:00 AM \\
\hline
\end{tabular}

As shown, numerous stations from both Entercom and Clear Channel often ran the same public affairs programs, with the same subject matter-sometimes at the very same time. When duplicate content ran at precisely the same time on multiple stations, it is highlighted here in red. Three Clear Channel stations and one Entercom station, for example, are all broadcasting the same material, nationally syndicated Viewpoints, at 7:30 Sunday mornings. And Sunday Magazine, a local program, runs at the same time, 7:00 AM Sundays, on four Clear Channel stations.

Source: Station Public Files 